Pontifícia Universidade Católica do Rio de JANEIRo

\title{
A Meditação em uma Pequena Empresa do Setor Têxtil
}

\section{Rafael Loureiro Dias de Macedo}

TRABALHO dE CONCLUSÃO DE CURSO

Centro de Ciências Sociais - CCS

DEPARTAMENTO dE AdMINISTRAÇÃO

Curso de Graduação em Administração 


\title{
Rafael Loureiro Dias de Macedo
}

\section{A Meditação em uma Pequena Empresa do Setor Têxtil}

\author{
Trabalho de Conclusão de Curso
}

Trabalho de conclusão de Curso, apresentado ao programa de graduação em Administração da PUC-Rio como requisito parcial para a obtenção do título de Bacharel em Administração.

Orientador: Paulo César Teixeira

Rio de Janeiro

6 de Junho de 2018. 
"Uma longa jornada começa num único passo" - Lao-Tse 


\section{Agradecimentos}

Gostaria de valer-me desta oportunidade para expressar meu mais profundo e sincero agradecimento aqueles que abençoaram este projeto. A realização deste presente trabalho não teria sido possível sem a participação, direta ou indireta, de todos aqueles que, de alguma maneira, me apoiaram, incentivaram, ajudaram e corrigiram, ao longo das diversas etapas de minha vida.

Um agradecimento profundo, que não cabe em palavras, para minha preciosa família, especialmente meus pais, Keilane e Marcelo. A vocês devo a vida e todo amor! Agradeço aos meus irmãos, Ricardo e Marcelo Loureiro Dias de Macedo, pelos ensinamentos, consideração e principalmente pelo companheirismo. Estendo um agradecimento especial a Daniela Valentina Dias e família. Assim como dirijo com regozijo meus agradecimentos para meus estimados avós, Maria Lúcia e Lásaro Antônio de Macedo, pela inspiração e devoção.

Meu sincero agradecimento pela guiança, amor e carinho, a minha amiga que tanto me ajuda e abençoa, Aline Lisboa Martins.

Com extrema gratidão e sinceridade, agradeço ao meu precioso mestre e guru, Venerável Segyu Choepel Rinpoche, sem cujo apoio e incentivo este trabalho nunca teria vindo a existir.

Agradeço especialmente à meu querido orientador, professor Paulo César Teixeira, pela confiança, orientação, incentivo e suporte.

Agradeço aos meus mestres, e aos mestres dos meus mestres.

Também gostaria de manifestar minha gratidão à Pontifícia Universidade Católica do Rio de Janeiro e seu corpo docente pelas oportunidades concedidas ao longo do curso. E é claro, muito obrigado à banca, cuja disponibilidade e orientação serão fundamentais para o aperfeiçoamento deste estudo e para o meu crescimento na vida acadêmica.

Muito grato à todos! 


\title{
Resumo
}

Loureiro Dias de Macedo, Rafael. Orientador: Teixeira, Paulo César. A Meditação em uma Pequena Empresa do Setor Têxtil. Rio de Janeiro, 2018. 59 páginas. Trabalho de Conclusão de Curso - Departamento de Administração. Pontifícia Universidade Católica do Rio de Janeiro.

Neste trabalho é empreendido um estudo de caso e uma pesquisa investigativa sobre a Meditação no ambiente empresarial, sob uma visão comportamental e holística. O objetivo do presente estudo é, com base nos dados coletados em pesquisa, procurar compreender e estabelecer a aplicabilidade da meditação no contexto organizacional, obter uma melhor compreensão dos efeitos e benefícios da prática da meditação, afim de refletir de que maneira a meditação pode beneficiar na qualidade de vida no trabalho (redução de estresse, etc.) e por conseguinte estabelecer um fundamento para a inserção/integração desta ferramenta na vida corporativa.

Este documento inclui esclarecimento a respeito do que se define por meditação, e quais práticas podem ser benéficas para a melhora na qualidade do trabalho no ambiente organizacional.

Palavras- chave: meditação, organizações, empresas, qualidade de vida no trabalho, redução de estresse e ansiedade.

\begin{abstract}
Loureiro Dias de Macedo, Rafael. Advisor: Teixeira ,Paulo César. The Meditation in a small company in the textile sector. Rio de Janeiro, 2018. 59 pages. Undergraduate Thesis - Department of Administration. Pontifical Catholic University of Rio de Janeiro.
\end{abstract}

This work has undertaken a case study and an investigative research on meditation in the business environment, in a behavorial and holistic view. Based on data collected during research, the aim of this study consists to understand and estabilish the applicability of meditation in the organizational context, get a better understanding of the effects and benefits of the practice of meditation in order to reflect how meditation could benefit the quality of work (stress redcution, etc) and therefore establish a foundation for the inclusion/integration of this tool in corporate life.

This document includes clarification about what is defined by meditation, and which pratices can be beneficial to the improvement in the quality of work in the organizational enviroment.

Key-words: meditation, business, companies, quality work life, stress and anxiety reduction. 


\section{Sumário}

1 . Introdução 1

1.1. Objetivo do Estudo 3

1.2. Objetivos Intermediários 3

1.3. Delimitação e Foco 3

1.4. Justificativa e Relevância 4

2. Revisão de Literatura 6

2.1. Mudanças e Transformações Ambientais 6

2.2. Definição de Meditação e suas Características 7

2.3. Apreciação Científica 9

2.4. Técnicas de Meditação 11

2.5. Benefícios e Efeitos da Meditação 13

2.6. A Meditação nas Organizações 16

$\begin{array}{ll}\text { 2.7. Qualidade de Vida (QV) } & 18\end{array}$

2.8. Qualidade de Vida no Trabalho (QVT) 20

2.9. Principais Aspectos da QVT 22

3. Métodos e Procedimentos de Coleta e Análise de Dados 25

3.1. Etapas de Coleta de Dados 25

3.2. Fontes de Informação Selecionadas para a Coleta de Dados 26

3.3. Dados sobre a Pesquisa do Programa de Meditação 26

3.4. O Procedimento de Coleta de Dados 26

$\begin{array}{ll}\text { 3.5. Limitações do Estudo } & 27\end{array}$

4 Descrição e Análise dos Resultados $\quad 29$

4.1. Resultados dos Questionários 29

4.1.1. A Empresa 29

4.1.2. O Programa de Meditação 30

4.1.3. Resultado das Entrevistas com os Gestores 39

4.1.4. Resultado do Encontro com o Especialista 46 
5. Conclusão 51

5.1. Sugestões e Recomendações para Novas Pesquisas 54

6. Bibliografia 55

$\begin{array}{ll}7 \text { Anexos } & 60\end{array}$

$\begin{array}{ll}\text { 7.1. Anexo A } & 60\end{array}$

7.2. Anexo B 62

7.3. Anexo C 65

$\begin{array}{ll}\text { 7.4. Anexo D } & 72\end{array}$ 


\section{Introdução}

O que é meditação? Por quê praticá-la? Por quê inserir a meditação no ambiente das organizações? Como meditar pode auxiliar na melhora da qualidade de vida no trabalho? Seria relevante meditar no trabalho? Seria importante estudar os efeitos da meditação? Este presente estudo tem como finalidade responder boa parte dessas perguntas e seus desdobramentos.

O crescente aumento da competitividade entre as empresas, oriundo de incontáveis fatores ocorridos no cenário mundial nas últimas décadas, têm obrigado as organizações a procurarem formas de se tornarem mais eficientes e competitivas. A necessidade de tornar as organizações mais resilientes e competitivas junto ao mercado, fomentou uma busca incessante para 0 desenvolvimento e a melhora de inúmeros fatores, incluindo as condições profissionais do corpo de colaboradores, focalizada no desenvolvimento do potencial do ser humano.

Partindo do princípio de que as empresas são envolvidas e compostas por seres humanos, conclui-se que as pessoas são as principais responsáveis por conduzir e produzir os resultados obtidos. Com base nesta questão central, algumas organizações estão voltando seus esforços e investindo em diversas maneiras de melhorar seus resultados a partir de seus colaboradores. De algum modo, administradores e gestores estão percebendo que promover a melhora da qualidade de vida de seus colaboradores torna a organização mais competitiva, saudável e produtiva. E nessa busca incessante, recentemente a meditação surgiu como uma forte tendência.

Prática milenar nos países orientais e ainda atualmente associada a religiosidade, a meditação vem conquistando de maneira relevante uma posição de destaque na vida ocidental. Detectada em inúmeras tradições religiosas, culturais e filosóficas, a meditação cada vez mais vem sendo absorvida e integrada tanto na atividade clínica contemporânea quanto no cotidiano da população ocidental.

Com o aumento do interesse público, a meditação tem sido objeto de pesquisa por parte das comunidades científicas e cada vez mais vem 
despertando a atenção das mais diversas organizações, desde empresas a instituições de ensino, prisões e hospitais.

Evidencia-se que o avanço nas pesquisas científicas e de neurociência além de inúmeros estudos recentes, vêm contribuindo de maneira incisiva para um aumento exponencial do interesse pela meditação no ocidente, ao passo que comprovam e demonstram os diversos efeitos e benefícios oriundos desta prática, uma vez exercida de forma regular resulta entre outros fatores, em um aumento do bem-estar físico, mental e emocional, contribuindo significativamente para a melhora na qualidade de vida.

Assim sendo, nota-se claramente que a figura da meditação encaixa-se perfeitamente no âmbito da qualidade de vida no trabalho, podendo esta ser definida pela busca do equilíbrio físico, psíquico e social onde são respeitadas as necessidades e limitações do ser humano, resultando num crescimento tanto pessoal quanto profissional (CHIAVENATO, 1999).

Em países desenvolvidos como os Estados Unidos da América bem como na Europa ocidental, a meditação está ganhando cada vez mais espaço no mundo corporativo, aliás, muitas organizações já contam com espaços físicos exclusivos para a prática de meditação afim de obter melhores resultados.

A grande questão atual é que parte das empresas no Brasil não se importam em oferecer 'qualidade de vida' aos colaboradores, e assim muitos empregados não desenvolvem uma motivação genuína para executar suas tarefas e realizar um bom trabalho. Aqui no Brasil, por conseguinte a prática de meditação não é desenvolvida nas organizações largamente, embora algumas empresas já estejam atentas aos seus benefícios, pois além de aumentar o grau de atenção na realização das tarefas, a meditação ajuda a desenvolver autoconfiança, permite que cada ação seja desempenhada com calma, além de melhorar a comunicação coletiva. A saída para tal problema seria propor que as organizações passem a observar a qualidade de vida no trabalho em face dos colaboradores como um meio de aumentar a motivação e consequentemente o desempenho e a produtividade das mesmas.

É neste contexto que se insere a empresa Elenice C. Leitão Confecção \& Beneficiamento ME, localizada no Rio de Janeiro, que confecciona majoritariamente roupas de vestuário feminino, e simultaneamente com o processo produtivo introduz a prática de meditação junto aos seus colaboradores.

Diante do exposto, tendo em vista os benefícios comprovados cientificamente da meditação e que a baixa qualidade de vida no trabalho produz 
naturalmente desequilíbrios e impactos negativos nos resultados das organizações, como por exemplo, índice alto de absenteísmos e rotatividade, baixa produtividade e inovação, etc., pode-se afirmar que, por este e outros motivos, a inserção da meditação no âmbito organizacional se trata de um assunto relevante no que tange a qualidade de vida no trabalho, e por conseguinte ao sucesso de uma organização.

Assim sendo, cabe indagar: as práticas de meditação inseridas no processo produtivo trazem melhoria na qualidade de vida no trabalho de uma empresa do setor têxtil?

\subsection{Objetivo do Estudo}

O objetivo do estudo é identificar os efeitos de um programa de meditação na melhoria da qualidade de vida no trabalho na ótica dos colaboradores da área de produção da empresa Elenice C. Leitão Confecção \& Beneficiamento ME.

\subsection{Objetivos Intermediários}

Para sedimentar e atingir o objetivo final proposto neste trabalho, foram delineados alguns objetivos intermediários, tais como:

$\Rightarrow$ Estudar os fundamentos teóricos de meditação;

$\Rightarrow$ Identificar a prática de meditação ocorrida na empresa objeto de estudo;

$\Rightarrow$ Comparar os fundamentos teóricos com a prática de meditação no ambiente de trabalho da empresa objeto de estudo;

$\Rightarrow$ Avaliar os resultados do programa de prática de meditação ocorrida na empresa, de acordo com os fundamentos teóricos observados;

$\Rightarrow$ Identificar os efeitos da prática na melhora da Qualidade de Vida no Trabalho na percepção dos colaboradores.

\subsection{Delimitação e Foco}

Este estudo aborda e analisa as influências do programa de prática de meditação de concentração, durante um período de oito semanas, entre os meses de Março e Maio de 2016, na empresa Elenice C. Leitão Confecção \& Beneficiamento ME, uma confecção de roupas estabelecida e situada na cidade do Rio de Janeiro/RJ. 


\subsection{Justificativa e Relevância}

O tema abordado, vem se revelando de extrema importância no que diz respeito a melhora na qualidade de vida do ser humano. E como não se pode existir empresas e organizações sem que haja a presença de seres humanos, a atenção voltada para a melhora na qualidade de vida do trabalho reflete e resulta diretamente na vida organizacional.

A cada dia que passa, aumentam os estudos científicos e teorias especializadas a respeito da meditação, demonstrando, de certa forma, o crescente interesse pelo tema. Estas pesquisas sugerem que o treinamento meditativo regular pode mudar a morfologia e a função cerebral, particularmente nas áreas relacionadas com a atenção e a seleção de resposta (HOELZEL et al., 2011). Esta observação pode apoiar os fatos de que a prática de meditação desenvolve a capacidade de manter a atenção para executar tarefas com menos interferência de distrações (BREFCZYNSKI-LEWIS et al., 2007). Além disso, a meditação pode também ter um efeito de reduzir a necessidade de controle de impulso, que consequentemente auxilia na redução de estresse. No entanto, no Brasil, embora a prática de meditar seja bem difundida, ainda existe uma escassez de estudos na área.

Apesar desta prática ser muitas vezes vista e encarada com algum ceticismo por grande parte do público, não faltam na verdade, motivos e evidências para se deixar influenciar.

Assim como um atleta ou desportista precisa de um corpo e de uma mente forte e saudável para alcançar sucesso e lograr êxito esportivo, da mesma maneira, no local de trabalho, se faz necessário manter o corpo, a mente e o cérebro a um nível ótimo, para que se possa responder aos desafios sem se desequilibrar (JUNIPER, 2016).

Somando ao fato de que nos dias atuais, o ambiente e o espaço no mercado de trabalho encontram-se cada vez mais acirrados, competitivos e mutantes, gerando consequentemente efeitos colaterais como ansiedade e estresse, a simples prática de voltar-se para si, observar a respiração, as emoções e sensações do corpo e da mente, surge como um elemento precioso e bastante eficaz para auxiliar na saúde e no bem estar do trabalhador, do mesmo modo que no processo de tomada de decisões da empresa.

Ademais, nota-se que o crescimento econômico dos países desenvolvidos, não gera, necessariamente, bem-estar à população como um todo. Verdade seja 
dita, em muitas nações, o desenvolvimento econômico tem incluído, como contrapeso, a subjugação de seres humanos a condições de vida inclementes, a condições desumanas de trabalho, a regimes de trabalhos degradantes e cruéis e a salários indecorosos, que de forma alguma proporcionam oportunidades para uma vida digna e sadia.

Vale ressaltar que, os avanços tecnológicos vêm implicando significativas transformações nas mais diversas áreas, sejam profissionais, pessoais, culturais ou sociais. Trata-se portanto de um momento desafiador, tanto de novas possibilidades e oportunidades quanto de incertezas e ameaças diante de tantas novidades e opções. Tais estímulos provenientes de todas as direções, ocasionalmente sobrecarregam não só o corpo como a mente, interferindo assim na capacidade de raciocinar, de estabelecer metas e prioridades, bem como caminhar na direção planejada.

Também é fato concreto, que grande parte das pessoas do mundo inteiro passa a maior parte de suas vidas no trabalho. Desta feita, cada vez mais as organizações interessadas em preservar e desenvolver seus funcionários, vêm oferecendo além de vantagens financeiras outras recompensas atrativas, como forma de promover e estimular uma melhora na produtividade e da satisfação interna.

Por conta destes fatos, no mundo inteiro muitas empresas, sejam elas de micro, pequeno, médio ou grande porte, vêm considerando os benefícios da meditação e estão buscando desenvolver e implantar espaços de descanso e reflexão, além de estimular a cultura da prática meditativa como forma de melhorar as condições do ambiente de trabalho e de modo consequente oferecer uma melhor qualidade de vida no trabalho.

Assim sendo, o tema abordado neste estudo se configura de extrema importância e relevância.

Além do mais, o trabalho serve de contribuição aos pesquisadores desta e de outras escolas de Administração, tais como grupos de pesquisa voltados para a questão da meditação no âmbito organizacional, tanto quanto para a inserção de ferramentas voltada para a melhora na qualidade de vida no trabalho.

Este presente estudo pode também, mediante as informações nele contidas, contribuir para estimular as organizações de um modo geral, a utilizarem a prática da meditação em face dos principais desafios que afligem a vida dos colaboradores e das sociedades corporativas. 


\section{Revisão de Literatura}

\subsection{Mudanças e Transformações Ambientais}

Presentemente a sociedade testemunha, a precarização das relações de trabalho, com desempregos e empregos por tempo indeterminado que, por consequência, produzem constante insegurança e estresse na população em geral (ABRAMIDES \& CABRAL, 2013).

As mudanças constantes, como por exemplo, do ambiente econômico, das relações sociais e políticas, na tecnologia, na organização produtiva e na própria inserção do elemento humano no tecido social e profissional, demonstram um cenário mutante, com novos modos de operar e trabalhar aliado a um novo regime de tempo implicado aos imediatismos, o que incide sobre a subjetividade e a maneira de viver dos indivíduos (GRISCI, 1999).

Todas essas transformações, ocorrendo simultaneamente, geram ambientes sociais e empresariais em ebulição, nos quais os fatores conjunturais de sobrevivência muitas vezes se sobrepõem aos objetivos de mudanças de longo prazo na sociedade que conduzam, efetivamente, as melhorias do bemestar dos cidadãos e das condições de vida (ALBUQUERQUE, 1992).

Desta forma, torna-se fundamental refletir a respeito da excitação da competitividade e da competição a qualquer preço e da respectiva repercussão na sociedade.

Juntamente com as soluções imediatas, responsabilidades e eficiências exigidas pelo modelo econômico vigente, o reflexo de tais tensões e estresses hoje atinge não somente a população adulta como também jovens e crianças que, por consequência, apresentam elevados níveis de desordem cognitivas e de comportamento (SOLARZ, 2009).

Hoje em dia, o fato de vivermos numa sociedade globalizada altamente conectada, acaba por instigar as mais variadas esferas e setores econômicos políticos a demandar esforços com a intenção de retificar suas práticas. Por conseguinte, a revelação de que o vigente modelo há muito aplicado se tornou ultrapassado no que tange a sua eficiência e eficácia, torna crucial a recapitulação de muitas das substanciais práticas executadas. 


\subsection{Definição de Meditação e suas Características}

Antes de discutir com maior profundidade o tema do estudo, faz-se necessário circunscrever e definir o que é meditação e quais tipos de prática meditativa estão sendo referidas.

Definir o que de fato é meditação a princípio parece tarefa fácil, porém trata-se de algo muito subjetivo, a medida que para cada pessoa a percepção acerca da meditação bem como seus efeitos são bastante peculiares e subjetivos.

Mas afinal, o que é meditação? Segundo o Dicionário da Língua Portuguesa Novo Aurélio (1999), meditação é, "ato ou efeito de meditar; concentração intensa do espírito; reflexão". Palavra originada do Latim meditare, significa voltar a atenção para dentro de si. Nas tradições orientais, deriva da palavra bhavana (em sânscrito) que significa desenvolver-se ou cultivar, e gon (em tibetano) que significa familiarizar-se. É assim definida como o desenvolvimento, o cultivo ou a familiaridade com determinados estados mentais e de consciência. Em outras palavras, meditar é o ato de concentrar-se em um objeto que vai empoderar a mente (JUNIPER, 2016).

Conhecida como uma prática milenar muito difundida, é reputada por se tratar de uma técnica contemplativa de promoção do autoconhecimento que possuí várias influências, cognitivas, emocionais e corporais. Pode-se definir meditação como uma prática que engloba um conjunto de técnicas que buscam treinar a focalizar a atenção (SHAPIRO \& WALSH, 1984).

Caracterizada como treino da atenção plena da consciência no momento presente, tem sido associada a um bem-estar físico, mental e emocional (SHAPIRO et al., 2005). Por essas e outras razões fomentou no mundo inteiro uma crescente busca pela prática pessoal, e de maneira análoga houve um notável aumento do interesse cientifico.

No Brasil, meditação é compreendida como uma técnica originada das filosofias orientais, especialmente ao vedanta, ao yoga e ao budismo (LEVINE, 2000), que se caracteriza por um processo ao longo do qual acontece um relaxamento mental e físico, auto-induzido pelo praticante, alcançado por meio de um objeto-foco (CARDOSO et al., 2004). Descrita como uma prática de autorregulação do corpo e da mente, caracteriza-se por um conjunto de técnicas que treinam a focalização da atenção. Também conhecida como treinamento 
mental, a prática regular constitui uma técnica capaz de produzir efeitos psicossomáticos (MENEZES, 2009).

A definição de meditação por si só caracteriza-se como uma prática mental que ativa processos biológicos, fisiológicos e psicológicos subjacentes a saúde e bem estar humano. Por sua vez, sua prática regular pode impactar as respostas emocionais e cognitivo-comportamentais dos indivíduos, e isto pode ser evidenciado em diferentes contextos e patologias, tal como em situações associadas a níveis elevados de estresse (JHA et al., 2010).

A prática da meditação cumpre muitas funções: auxilia na superação problemas e obstáculos interiores, como aqueles criados pela raiva, inveja, apego e ignorância; controla nossa mente e acarreta paz interior; habilita-nos a cultivar intenções virtuosas, que nos levam a praticar boas ações; elimina intenções não virtuosas que nos levam a cometer ações prejudiciais (GYATSO, 1999).

O mecanismo de foco ou atenção envolvido na prática meditativa, ou melhor, no ato de meditar é, segundo Shapiro \& Walsh (1984), a própria base de sua definição, cujas técnicas mais variadas teriam em comum uma tentativa consciente de focalizar a atenção em um objeto de escolha, tal como um som, palavra ou respiração. Desta maneira a atenção, é uma das funções cognitivas no processo meditativo e particularmente envolvida nas mudanças que a prática pode gerar (MENEZES \& DELL'AGGIO, 2009).

Ou seja, podemos definir resumidamente a meditação como o ato de concentrar-se em objeto que empodera e fortalece a mente, beneficiando a saúde física e mental, e promovendo um bem estar (JUNIPER, 2016). Sendo que os efeitos de uma intervenção prática de oito semanas de meditação sobre a diminuição dos sintomas do transtorno de ansiedade generalizada entre outros pode ser sustentada e mantida por um período de até três anos (DAVIDSON \& GOLEMAN, 1976; KRISTELLER \& HALLET, 1999).

Assim como a prática meditativa auxilia na diminuição da ansiedade, ela também está associada a redução do estresse. É justamente através desses efeitos que a meditação pode ser benéfica para diversas condições de saúde (GROSSMAN et al., 2004).

A meditação possui a capacidade de estimular aspectos saudáveis, muitas vezes vinculado a saúde mental. Pesquisas verificaram que a meditação provoca ativação do córtex pré-frontal esquerdo, região cerebral que se associa a uma maior resiliência e a afetos positivos (DAVIDSON, 2004). 
Para a obtenção deste estado de consciência dito meditativo, as mais variadas técnicas e suas variações buscam ancorar a atenção da pessoa em um objeto-foco, permitindo que a mente, livre de distrações, se estabeleça firmemente no momento presente.

$\mathrm{Na}$ atualidade, com a globalização e a chegada de inúmeras práticas e novas técnicas do mundo oriental para o ocidente, a prática da meditação tem sido largamente utilizada para fins terapêuticos, como para controle do estresse e para a melhora na qualidade de vida. Estudos mais aprofundados vêm demonstrando que o senso de objetividade, atenção e memória também são significativamente apurados com a prática regular. Com isto, os benefícios desta prática têm se mostrado tão notórios e evidentes, que a meditação se transformou em objeto de estudo da neurociência (GOLEMAN, 1997).

De acordo com Rinpoche (2016), tendo em vista que a qualidade de nossas experiências é determinada pela qualidade de nossa mente, através do treinamento mental pode-se transformar a qualidade das experiências sem precisar mudar as experiências em si.

Segundo Goleman (1997), a meditação é o principal meio para transformar qualidades ideais em traços estáveis. E trata-se justamente desta característica que impulsionou a chegada da meditação no meio científico ocidental.

\subsection{Apreciação Científica}

O avanço nas pesquisas na área da neurociência vêm justamente demonstrando que a meditação pode ser benéfica à saúde física e mental dos seres humanos, contribuindo significativamente para a melhora da qualidade de vida do praticante. Esse fenômeno proveniente da meditação tem sido observado com investigações que utilizam critérios e bases científicas como medidas fisiológicas tanto quanto auto-relato dos adeptos e praticantes (SANTI, 2018).

Por volta de 2006, considerando as evidências comprovadas através de pesquisas científicas, o governo dos Estados Unidos da América, através da agência responsável por diversas pesquisas médicas, National Institutes of Health, reconheceu a meditação como uma prática terapêutica, autorizando assim a sua utilização como tratamento complementar a medicina convencional (GOMES, 2016). No mesmo ano, o Ministério da Saúde do Brasil regulamentou por meio da portaria $n^{\circ} 971$ a adoção pelo Sistema Único de Saúde (SUS) de 
terapias como a meditação, incentivando os postos de saúde e hospitais públicos a oferecê-las em todo território nacional (BRASIL, 2006).

Embora conste que desde de 1936 o potencial da meditação vem despertando curiosidade no meio científico, apenas por volta de 1960 a meditação tratou de ser objeto de rigoroso estudo. Uma das pesquisas mais proeminentes teve início com o doutor Herbert Benson, professor da Escola de Medicina da Harvard University, no começo da década de 60, que com uma amostra de pessoas que praticavam uma determinada técnica de meditação, começou uma investigação minuciosa (BENSON, 1975; LEVINE, 2000).

Neste estudo liderado pelo Benson (1975), os participantes da pesquisa praticavam a técnica da Meditação Transcendental, na qual o meditador senta quietamente e concentra sua mente em uma frase (mantra), que é repetida silenciosamente durante um período de vinte minutos. Surge como resposta aos estímulos da prática, mudanças fisiológicas e bioquímicas significantes que permanecem um longo período de horas depois de terminada a prática, proporcionando melhora na saúde do adepto.

Conforme Benson (1975), a explicação técnica do fenômeno de relaxamento durante a meditação ocorre por conta da estimulação do parassimpático diminuindo o número de batimentos do coração, que bate mais lentamente. A respiração se torna mais lenta, diminui a quantidade de oxigênio consumida pelo corpo, há relaxamento muscular, tendo em vista que a tensão muscular fica abaixo dos níveis de repouso e nota-se também a diminuição da pressão sanguínea. Ocorre redução dos processos metabólicos orgânicos que leva a um estado de baixo metabolismo. Simultaneamente ocorrem modificações das ondas elétricas cerebrais com predomínio das lentas, alfa e teta, além de alterações hormonais.

Benson (1975), denominou estas mudanças de relaxation response, ou melhor traduzindo, respostas de relaxamento, e considerou-as opostas a resposta de estresse. O mesmo pesquisador, levantou a hipótese que a resposta de relaxamento poderia ter como efeito a melhoria da saúde, pois protegeria o organismo da ação nociva do estresse. A continuidade da prática do relaxamento poderia proporcionar um sentimento de maior controle sobre a vida do praticante, que pode vir a controlar e equilibrar suas emoções, por sua vez na administração de estresse e da ansiedade depois de meses de prática.

De maneira complementar, em seu livro Medicina Espiritual (BENSON, 1992) o pesquisador atesta que boa parte das consultas médicas poderiam ser 
evitadas se as pessoas utilizassem a mente para combater as tensões causadoras de complicações físicas.

Como decorrência das pesquisas de Benson, nas últimas décadas centenas de pesquisas foram realizadas, levantando e confirmando as hipóteses de que as inúmeras formas de meditação são úteis para o tratamento de diversas doenças orgânicas e mentais. Entre elas destacam-se as pesquisas lideradas pela neurocientista e doutora em filosofia, a americana Sara W. Lazar (Universidade de Harvard) e o pesquisador americano e $\mathrm{PhD}$ em biologia molecular Jon Kabat-Zinn (Instituto de Tecnologia de Massachusetts) (SANTI, 2018).

\subsection{Técnicas de Meditação}

A partir de uma revisão literária, nota-se que diversos resultados encontrados a partir de diferentes técnicas são bastante similares. Baseado nessa percepção e no fato de que técnicas distintas possuem características essenciais comuns, a investigação científica parte da premissa, que apesar de existirem inúmeras técnicas, todas possuem uma característica essencial comum: o controle da atenção (GOLEMAN,1988).

No ocidente são aplicadas e empregadas diversas técnicas de meditação com finalidade psicoterapêutica e médica. Em geral, destacam entre elas, meditação da mente alerta (mindfulness) e a concentrativa (GOLEMAN, 1988).

A técnica do tipo mindfulness, é descrita como uma prática de abertura, em que ocorre uma percepção dos estímulos, como sensações, sentimentos e pensamentos, apesar de que o objeto de atenção especifico seja uma observação livre que não os analisa, nem os julga ou conceitua. Certos métodos orientais de meditação se enquadram neste tipo, como a meditação zen (MENEZES \& DELL'AGLIO, 2009).

Já a técnica meditativa do tipo concentrativa tem como característica fundamental restringir a atenção em um único objeto, interno ou externo. Ignorase qualquer estímulo do ambiente, focalizando tão somente a concentração em uma atividade mental ou sensorial específica, como por exemplo, uma imagem, a respiração ou a repetição de um som. Nesta técnica enquadra-se a Meditação Transcendental, Shamatha e outras oriundas da Yoga e do Budismo (MENEZES \& DELL'AGLIO, 2009). 
Segundo Goleman (1988), muitas vezes é preciso treinar a concentração primeiramente, para só então conseguir desenvolver-se à observação livre de julgamento dos conteúdos mentais, como propõe o método mindfulness.

Existem argumentos que atestam a existência de um outro tipo de técnica, denominada meditação de contemplação, que a grosso modo seria uma junção dos outros tipos supracitados, a medida que une tanto a habilidade de se concentrar como de se abrir. Determinadas orações e meditações religiosas compreendem alguns exemplos de meditações contemplativas (SHAPIRO \& WALSH, 1984).

Dentre os diversos métodos e abordagens de meditação, existe basicamente quatro elementos e aspectos em comum em todas elas: um local, de preferência tranquilo, com tão poucas distrações quanto possível; uma postura confortável específica (sentado, em pé ou em outras posições); um período de duração (tempo); e o estabelecimento de um objeto de concentração. Se esses aspectos forem compreendidos, de certo modo se estabelece a prática de meditação (JUNIPER, 2016).

Cardoso et al. (2009), com o intuito de padronizar a definição da meditação para fins científicos e clínicos, ressalta a meditação conforme alguns parâmetros:

$\Rightarrow$ é um estado auto-induzido, autoaplicável;

$\Rightarrow$ é um estado obtido por uma técnica específica, claramente definida;

$\Rightarrow$ algum tipo de foco (âncora) é utilizado para evitar envolvimento com as sequências de pensamentos, sensações ou distrações;

$\Rightarrow$ envolve um estado de não-julgamento, sem expectativas;

$\Rightarrow$ em algum ponto do processo, instala-se um relaxamento psicofísico, com relaxamento muscular mensurável.

Conforme Swearer (1973), os passos para a meditação são os seguintes:

$\Rightarrow$ Sentar-se em posição confortável, com a coluna ereta e fechar os olhos. Soltar o corpo e relaxar os músculos.

$\Rightarrow$ Respirar naturalmente, sem interferir na respiração. Sentir o ar entrar e sair livremente nas narinas ou nos pulmões. 
$\Rightarrow$ Quando surgir qualquer pensamento, sentimento ou sensação em sua mente não se fixar em nenhum. Acompanhar de cada um o aparecimento e a extinção.

$\Rightarrow$ Não fazer nenhuma avaliação do que surgir, nenhum julgamento, se é bom ou ruim, agradável ou desagradável. Contemplar o que surge durante sua permanência na mente.

Além das condições específicas de cada técnica, outras variáveis, como traços de personalidade, vivências e experiências de cada pessoa, motivações, valores e expectativas bem como predisposições genéticas também podem influenciar o tipo e a qualidade da resposta que a prática meditativa produzirá (DAVIDSON \& GOLEMAN, 1976).

\subsection{Benefícios e Efeitos da Meditação}

Contudo é importante observar que os benefícios e efeitos da meditação são somente alcançados de maneira sustentável a partir da prática regular, repetitiva e habitual. A meditação é uma habilidade aprendida, e sua competência se desenvolve ao longo do tempo. A proficiência em meditação é adquirida através de repetido esforço (LAZAR et al., 2005).

De acordo com o Dicionário Novo Aurélio da Língua Portuguesa (1999), a palavra hábito significa disposição adquirida pela repetição frequente de um ato.

Rocha \& Christensen (1999), afirmam que o hábito faz parte do processo de aprendizado, tratando-se de um processo de recepção de estímulos que desencadeiam respostas com o intuito de estabelecer um comportamento dentro de um determinado padrão. Desta forma quanto mais forte consistir o hábito, maior a probabilidade de que o individuo alcance os benefícios da meditação.

Segundo Durant (1926), "nós somos aquilo que fazemos repetidas vezes, repetidamente. A excelência, portanto não é um modo de agir, mas um hábito". Sendo assim neste contexto, temos senão duas opções: incorporar novos hábitos que nos permitam evoluir e abandonar velhos hábitos que atrasam nosso desenvolvimento, ou continuar os mesmos.

Diversos são os benefícios e efeitos da prática meditativa, a maioria de caráter fisiológico, mental e emocional. Dentre os muitos efeitos, os mais conhecidos são (KHALSA, 2001):

$\Rightarrow$ relaxamento físico, mental, emocional e metabólico; 
$\Rightarrow$ redução de estresse;

$\Rightarrow$ equilíbrio da emoções;

$\Rightarrow$ melhoria do sistema cardiovascular;

$\Rightarrow$ combate a insônia;

$\Rightarrow$ alívio da dor;

$\Rightarrow$ reforço do sistema imunológico;

$\Rightarrow$ estimulação da criatividade;

$\Rightarrow$ melhoria da concentração e raciocínio.

Atualmente, é de conhecimento geral que, além dessas mudanças funcionais, a meditação pode também produzir mudanças estruturais no cérebro, atuando sobre a plasticidade cerebral (LAZAR et al., 2005), corroborando à idéia de que a regularidade e a continuidade da prática influenciam a intensidade das respostas e que, portanto, a meditação pode produzir tais transformações (KOZASA et al., 2012).

A atenção se define como uma das funções cognitivas que aparenta estar particularmente envolvida nas transformações e mudanças que o exercício da meditação pode gerar (KOZASA et al., 2012).

Sintomas relativos ao estresse, de maneira particular, vem apresentando resultados significativos após a prática de meditação, tanto com populações clínicas e como em populações não clínicas, conforme apontam as medidas de sofrimento (distress) psicológico e marcadores biológicos (GOLEMAN \& SCHWARTZ, 1976).

Segundo Khalsa (2001), um dos efeitos que meditação produz está relacionado com a redução do lactato do sangue (que se caracteriza por ser um marcador químico do estresse), e também do cortisol (um dos hormônios relativos ao estresse).

A prática meditativa está associada também à redução da ansiedade (Schwartz et al., 1978). Além disso, indivíduos com o transtorno de comer compulsivo que passaram por uma intervenção utilizando de alguma forma a meditação tiveram a intensidade e frequência de seus episódios diminuídas em função da redução da ansiedade (KRISTELLER \& HALLETT, 1999).

De acordo com Jain et. al (2007), a meditação pode proporcionar o desenvolvimento de características psicológicas positivas por meio da redução da distração bem como de pensamentos ruminativos. Ao realizar a comparação dos efeitos da meditação e do relaxamento corporal, os autores puderam 
verificar que, apesar das técnicas produzirem uma redução do sofrimento psicológico e um aumento de afetos positivos, a meditação teve um tamanho de efeito maior no aumento dos afetos positivos. Além disso, a meditação foi a única técnica com efeito sobre a redução de comportamentos e pensamentos ruminativos.

Em razão desta relação entre aspectos psicológicos positivos e meditação, muitos pesquisadores e autores a concebem como uma técnica extremamente útil para tratamentos psicoterápicos (MARTIN, 1997; NARANJO, 2005).

Conforme relatado em um artigo digital da Harvard Business Review (2015), uma equipe de cientistas da University of British Columbia (Canadá) e da Chemnitz University of Technology (Alemanha) reuniu dados de mais de 20 estudos e descobriu que pelo menos oito regiões diferentes do cérebro são consistentemente afetadas pela prática de meditação. De particular interesse para os executivos e profissionais de negócios, relatam os três autores do artigo, é o efeito da meditação no córtex cingulado anterior, uma região frontal que está associada à autorregulação. Os participantes da pesquisas que meditaram apresentaram desempenho superior em testes de autorregulação e também apresentaram mais atividade nessa região do cérebro do que aqueles que não meditaram. Outra região do cérebro que parece se beneficiar da meditação é o hipocampo, parte do sistema límbico associado à emoção e à memória (CONGLETON, HÖLZEN \& LAZAR, 2015).

De uma maneira geral, pode-se concluir que a experiência oriunda da prática de meditação se reflete de inúmeras formas, com a predominância de efeitos e benefícios cognitivos, físicos e emocionais, e que o ato de meditar se constitui com uma ferramenta para o desenvolvimento psicológico saudável. Além destes efeitos, a meditação repercute em inúmeros âmbitos da vida. Entrevistas indicam que muitos praticantes meditadores buscam integrar sua prática ao seu ambiente de trabalho, mencionando entre outros fatores, uma melhora na qualidade do trabalho, melhora na tomada de decisões e melhora da qualidade nas relações interpessoais (DUERR, 2004; MENEZES, 2009).

Justamente a partir da descoberta desses efeitos e benefícios, a meditação passou a ser uma intervenção utilizada como ferramenta organizacional nas mais variadas empresas (JUNIPER, 2016). 


\subsection{A Meditação nas Organizações}

O recurso à meditação proveniente da tradição budista indo-tibetana tem sido cada vez mais aplicado na vida das organizações (TIMM, 2010). A meditação, seja ela atrelada a técnica da atenção plena (mindfulness) ou de outras técnicas, é uma prática utilizada por grandes empresas como é o exemplo da Google (Search Inside Yourself) (RINPOCHE, 2016), assim como por atletas de alto rendimento, celebridades e executivos de multinacionais, para que durante situações de crise ou de grande tensão se consiga controlar as emoções e atingir um estado de serenidade (SANTI, 2018).

De olho nos benefícios oriundos da meditação, grandes empresas como Facebook, Twitter, Linkedin, Google, assim como seus executivos utilizam aspectos básicos da técnica para melhorar a qualidade de vida e o ambiente de trabalho. O engenheiro Chade-Meng Tan, funcionário número 107 e desde 2000 na Google, criou um programa de meditação mindfulness para os funcionários da organização chamado 'Search Inside Yourself' ("busque dentro de você"). Segundo Tan, boa parte dos benefícios resultantes da prática são alcançados após cerca de 7 semanas de meditação (TAN, 2012).

Ademais, a prática da meditação vem sendo exercida com sucesso em hospitais, escolas e presídios ao redor de todo o globo terrestre, tamanha a sua eficácia na resolução de conflitos, entre outros fatores. Conforme exibido no filme documentário "Doing Time, Doing Vipassana", presídios na Índia, como o Complexo Penitenciário de Tihar, em Nova Déli, adotaram a meditação (vipassana) como possível solução de conflitos entre a população carcerária (DOING TIME, DOING VIPASSANA, 1997).

Segundo uma reportagem veiculada na Folha de São Paulo em 2013, a pesquisadora e doutora em filosofia Sara Lazar, do Hospital Geral de Massachusetts, afirma que hospitais universitários nos Estados Unidos, através de inúmeras pesquisas vem comprovando que a técnica pode ser utilizada como terapia complementar no tratamento de doenças e também como forma de aliviar os sintomas de estresse e ansiedade, tanto em funcionários como em pacientes (VINES, 2013).

Gonzáles (2009), refere-se a meditação como uma prática que consegue efetivamente criar ambientes mais calmos entre os praticantes pois eles passam a controlar melhor suas emoções e gerir melhor o estresse no ambiente no qual estão inseridos e no local de trabalho. $O$ autor também acrescenta que a meditação pode ser uma das soluções para a redução do valor que a gestão de 
conflitos tem custado às empresas americanas, tendo em consideração o absentismo e a diminuição do rendimento e performance. Os colaboradores ao verem os seus níveis de concentração melhorados tornam-se mais criativos como testemunham alguns dos seus clientes entre os quais se destacam: BMO Financial Group e Conference Board of Canadá (GONZÁLES, 2009).

Inúmeros estudos e pesquisas vêm sendo realizados no sentido de perceber e conhecer de que forma determinadas práticas de meditação tem ou não algum reflexo também na saúde. Essas mesmas pesquisas tem analisado a importância do papel das organizações na redução da violência quer no ambiente de trabalho, quer na sociedade (BISHARA \& SCHIPANI, 2010). Para tal, as organizações precisam proporcionar benefícios alternativos como uma maneira de promover um espírito de comunidade entre os colaboradores. Os autores afirmam que o estresse tem efeitos físicos, psicológicos e comportamentais negativos, os quais poderão ser atenuados por intermédio da implementação de programas que contribuam para o aumento do bem estar e da produtividade da força de trabalho. Argumentam que um caminho para alcançar tais objetivos, poderia ser através da concepção de programas de meditação dentro das companhias e organizações (BISHARA \& SCHIPANI, 2010).

Quando as organizações implementam práticas, como a meditação, no local de trabalho, estas traduzem-se em benefícios individuais e organizacionais, uma vez que, os colaboradores conseguindo atribuir significado ao seu trabalho, sentem-se atraídos por este e experimentam maior satisfação, fator que normalmente está associado ao desempenho e performance da organização (FRY, 2013).

Conforme estudo e pesquisa da University of Califórnia - Irvine e da Humboldt University apontam, normalmente cada trabalhador típico é interrompido ou distraído em média a cada 11 minutos (uso de redes sociais, telecomunicações, etc.), levando depois cerca de 25 minutos para retornar a tarefa, quando conseguem, provocando perda de produtividade (GUDITH, KLOCKE \& MARK, 2008).

Portanto, as interrupções e distrações no ambiente de trabalho configuramse como uma das principais razões apontadas nos estudos que justificam a implementação da meditação nas empresas como propósito de manter e aumentar o nível de concentração, e consequentemente a produtividade dos colaboradores (TIMM, 2010). 


\subsection{Qualidade de Vida (QV)}

Desde tempos longínquos a preocupação com a Qualidade de Vida (QV) sempre esteve presente na sociedade humana e foi contemplada por diversos pensadores. Arquimedes de Siracusa (287, a.C.), famoso matemático, físico, engenheiro e inventor do mundo antigo, utilizou-se da lei das alavancas para reduzir o esforço físico dos trabalhadores. Por sua vez na Alexandria, Euclídes (300, a.C.), utilizou os princípios da geometria para facilitar o trabalho dos agricultores da época (VASCONCELOS, 2001). Nestes casos em específico, a Qualidade de Vida é representada pela busca da redução do excessivo esforço físico dos trabalhadores bem como para promover a satisfação dos indivíduos.

Segundo o Dicionário da Língua Portuguesa Novo Aurélio (1999), a palavra "Qualidade" refere-se a "propriedades, atributos ou condições das coisas que as distingue das outras...; superioridade, excelência de algo". Em outros termos, refere-se a determinadas características avaliadas como indicadores de primazia, excelência, superioridade em relação a determinado conteúdo. Já no que diz respeito ao vocábulo "Vida", é definido como "conjunto de qualidades graças as quais animais e plantas se mantêm em contínua atividade, existência; modo de viver; força, vitalidade". Em um contexto específico, caracteriza-se como uma categoria que inclui saúde equilibrada, relações interpessoais e familiares saudáveis, condições matérias estáveis, entre outros fatores.

A Constituição da Organização Mundial de Saúde (OMS), organismo sanitário internacional integrante da Organização das Nações Unidas, em seu preâmbulo define o conceito de saúde como "um estado completo de bem estar físico, mental e social, e não meramente a ausência de enfermidades ou invalidez (OMS, 1946)". Por conseguinte, a saúde representa o indivíduo como um todo, de modo integral, como um ser "bio-psico-sócio-espiritual". Em outras palavras, leva-se em conta não apenas aspectos físicos, mas psicológicos, ambientais, culturais, inclusive aspectos de conotações espirituais (RINPOCHE, 2016).

É notório que fatores psicológicos influenciam diretamente a saúde física, originando possivelmente uma variada gama de patologias incluindo desordens e distúrbios psicossomáticos, além de possibilitar ou provocar o surgimento de diversas alterações mentais. Neste contexto, tanto a saúde mental quanto física do indivíduo são condicionadas ou afetadas pelas circunstâncias socioculturais que o envolvem (RINPOCHE, 2016). Segundo a OMS, o bem estar ou a saúde 
do indivíduo pode ser afetado não somente pela ocorrência de fatores de risco, como também pela presença de condições adversas e/ou pela deficiência ou ausência de fatores ambientais.

A partir do instante que a OMS define o conceito de saúde, certos indicadores além dos tradicionais índices de saúde foram considerados para caracterizar um indivíduo ou uma determinada conjuntura saudável. Diante de tal medida elucidativa, boa parte dos profissionais e especialistas passaram a se devotar não apenas a fomentar a promoção de ganhos e bens estritamente econômicos, como também investigar e considerar a influência desses bens sobres os indivíduos e na maneira na qual eles conduziam suas vidas.

Entretanto, como não existe um consenso a respeito da definição de Qualidade de Vida, a Organização Mundial da Saúde (OMS) constituiu um grupo de Qualidade de Vida, World Health Organization Quality of Life (WHOQOL), com o propósito de criar mecanismos capazes de realizá-lo dentro de uma perspectiva transcultural. Assim o Grupo WHOQOL define Qualidade de Vida como a percepção do indivíduo sobre a sua posição na vida no contexto da cultura e dos sistema de valores em que vive e em relação aos seus objetivos, expectativas, padrões e preocupações. É um conceito abrangente e multidimensional influenciado de forma complexa, tanto por componentes objetivos quanto subjetivos, como por exemplo pela saúde física, estado psicológico, crenças pessoais, relações sociais e suas relações com as características relevantes de seu ambiente (WHOQOL, 1995).

Resumidamente, a instituição OMS/WHOQOL define a Qualidade de Vida de acordo com a abrangência de seis enfoques principais: saúde física, saúde psicológica, nível de independência, relações sociais, meio ambiente e aspectos espirituais/crenças pessoais (FLECK et al. 1999).

A Qualidade de Vida (QV) é uma noção eminentemente humana, que tem sido aproximada ao grau de satisfação encontrado na vida familiar, amorosa, social e ambiental e à própria estética existencial. Pressupõe a capacidade de efetuar uma síntese cultural de todos os elementos que determinada sociedade considera seu padrão de conforto e bem-estar. O termo abrange muitos significados, que refletem conhecimentos, experiências e valores de indivíduos e coletividades que a ele se reportam em variadas épocas, espaços e histórias diferentes, sendo, portanto, uma construção social com a marca da relatividade cultural (MINAYO et al., 2000).

Portanto, para se falar de Qualidade de Vida, como uma sensação de bem-estar do indivíduo proporcionada pela satisfação de condições objetivas 
(emprego, moradia, etc.) e de condições subjetivas (afeto, reconhecimento, segurança, etc.), temos de entrar no campo da motivação humana, buscando descobrir quais as necessidades do homem e o que aspira como realização de vida. A Qualidade de Vida importa em consciência individual e social sobre o significado da vida para que o homem coloque sua força transformadora em sua realização plena (MATOS, 1996).

Em contrapartida, segundo Fernandez-Ballesteros (2004), qualidade de vida não é sinônimo somente de saúde física, de qualidade de ambiente ou de quantidade de bens materiais. A qualidade de vida também se distingue da felicidade ou satisfação e não se reduz meramente as condições externas de vida ou responsabilidade pessoal. Deste modo não se pode considerá-la como uma questão de caráter meramente intrínseco ou extrínseco, tendo em vista que é impossível desassociar o individuo de sua interação recíproca com o meio.

\subsection{Qualidade de Vida no Trabalho (QVT)}

A sociedade ainda vive certos paradigmas sobre os modos de vida dentro e fora das empresas, edificando novos valores relativos as demandas da Qualidade de Vida no Trabalho (QVT) (ALBUQUERQUE \& FRANÇA, 1998).

Dentre os inúmeros desafios que se apresentam no mundo corporativo, dois são fundamentais. O primeiro é relativo a necessidade de uma força de trabalho preparada, motivada e saudável. O segundo desafio se caracteriza pela capacidade da organização de responder a demanda para seus colaboradores em relação a uma melhor qualidade de vida no trabalho (SILVA \& DE MARCHI, 1997).

O clima organizacional atualmente caracteriza-se pelo trabalho temporário e precário, e os valores e diretrizes das organizações tornam-se suspeitos porém, mesmo assim, para os trabalhadores continua a ser fundamental encontrar nas organizações o significado do trabalho que executam no seu diaa-dia, uma vez que compreende o lugar onde passam grande parte do tempo das suas vidas (ASHMOS \& DUCHON, 2000).

Um lugar adequado para se trabalhar possivelmente deve oferecer, entre outros fatores, que os colaboradores disponham, além do trabalho, outros compromissos em suas vidas, como família, amigos, etc. A importância da Qualidade de Vida no Trabalho é mais que mera política de redução de custos, pois a QVT possibilita o bom convívio entre a pessoa e a organização na qual 
trabalha. Ter certos benefícios que satisfaçam os anseios dos indivíduos e oferecer um bom ambiente pode garantir um clima de confiança entre a organização e o trabalhador (LEVERING, 1986).

A Qualidade de Vida no Trabalho é mais do que a saúde e segurança no trabalho. É preciso vinculá-la a qualidade integral e a melhoria do clima organizacional, oferecer condições adequadas, bem como respeitar e ser respeitado como profissional (VASCONCELOS, 2001).

Além do mais, alcançar qualidade de vida se caracteriza como uma legítima vontade humana presente em todos os indivíduos, que buscam tudo que possa prover maior equilíbrio físico, psíquico, social, além de obter uma vida mais satisfatória e proporcionar um maior bem estar (SUMARIVA \& OURIQUES, 2010).

Muitos pesquisadores salvaguardam que a qualidade de vida no trabalho pode ser entendida como uma estratégia, cujo objetivo principal volta-se para a conciliação dos interesses dos indivíduos e das organizações em face da melhora da satisfação do trabalhador e da melhora no desempenho produtivo da organização (FERNANDES, 1996).

Segundo França (1997), qualidade de vida no trabalho (QVT) é o conjunto das ações de uma empresa que envolvem a implantação de melhorias e inovações gerenciais e tecnológicas no ambiente de trabalho. A construção da qualidade de vida no trabalho ocorre a partir do momento em que se olha a empresa e as pessoas como um todo, o que chamamos de enfoque biopsicossocial. O posicionamento biopsicossocial representa o fator diferencial para a realização de diagnóstico, campanhas, criação de serviços e implantação de projetos voltados para a preservação e desenvolvimento das pessoas, durante o trabalho na empresa. A autora da mesma forma elucida que a origem do conceito vem da medicina psicossomática que propõe uma visão integrada, holística do ser humano, em oposição a abordagem cartesiana que divide o ser humano em partes. E realiza, ao alegar que no contexto do trabalho esta abordagem pode ser associada a ética da condição humana. Esta ética busca desde a identificação, eliminação, neutralização ou controle de riscos ocupacionais observáveis no ambiente físico, padrões de relações de trabalho, carga física e mental requerida para cada atividade, implicações políticas e ideológicas, dinâmica da liderança empresarial e do poder formal até o significado do trabalho em si, relacionamento e satisfação do trabalho.

De acordo com Chiavenato (1999), a qualidade de vida tem se sedimentado um fator chave nas organizações e está diretamente ligada a 
maximização do potencial humano, e isto depende da maneira como as pessoas se sentem trabalhando na organização.

De maneira análoga com tal afirmativa, Chiavenato (1999), afirma que o colaborador, quando motivado, tem maior disposição e capacidade para desempenhar suas funções e atividades de trabalho. Desta feita, as organizações, para conseguirem de seu corpo de colaboradores uma melhor produtividade, precisam investir nos mesmos, proporcionando maior satisfação e motivação para a realização das próprias atividades laborais.

Diante disso, se nota que a motivação no trabalho é um aspecto fundamental para que o funcionário obtenha melhor rendimento e comprometimento com seu trabalho. Portanto, aquela organização que de maneira enfática promove a motivação de seus funcionários e colaboradores consequentemente exibirá uma maior produtividade e desempenho, além de proporcionar melhor qualidade de vida bem como um ambiente de trabalho agradável e acolhedor (CHIAVENATO, 1999).

Vale ressaltar, que segundo Freitas (1999), não está sendo solicitado que as empresas abram mão de sua visão monetarizada de mundo, mas que elas honrem em ações o que costumam pregar em discursos que dizem que o ser humano é o seu principal "ativo".

\subsection{Principais Aspectos da QVT}

De fato, conforme Fernandes (1996) são inúmeros os benefícios da Qualidade de Vida no Trabalho (QVT), dentre eles sobressaem-se:

$\Rightarrow$ aumento da produtividade;

$\Rightarrow$ redução da rotatividade;

$\Rightarrow$ eliminação/redução da fadiga;

$\Rightarrow$ desenvolvimento das capacidades humanas;

$\Rightarrow$ integração social;

$\Rightarrow$ promoção da saúde;

$\Rightarrow$ redução do absenteísmo;

$\Rightarrow$ melhoria no ambiente de trabalho;

$\Rightarrow$ maior motivação. 
De acordo com Chiavenato (1999), as pessoas podem aumentar ou reduzir as forças e fraquezas de uma organização dependendo da maneira como são tratadas. Elas podem ser fonte de sucesso como podem ser fontes de problemas.

$\mathrm{Na}$ opinião de Ballone (2006), alguns dos fatores que mais influenciam a qualidade de vida no trabalho, podem ser: ruídos, sobrecarga no trabalho, alteração do sono, a falta de perspectivas, mudanças determinadas pela empresa, bem como mudanças auto-impostas.

Conforme afirma Marins (2003), o maior problema que ocorre nos dias atuais é que as empresas tem pressa. Muita pressa. Querem resultados rapidamente. Desta maneira, quando uma pessoa se depara sob tamanha pressão, começa a se sentir preocupada, passa a duvidar se realmente vai conseguir atingir o que deseja, e esta ansiedade pode levar ao estresse, ocasionando inúmeros problemas organizacionais.

Ressalta-se que, antes que a implementação de qualquer programa de QVT ocorra é essencial identificar e observar atentamente as necessidades das pessoas que compõe a empresa, alinhando as necessidades da organização com os objetivos e necessidades do individuo. Sendo assim, se faz necessária a participação e o apoio de todos os membros (AQUINO,1979).

A filosofia corporativa e a cultura organizacional de uma empresa é um sistema compartilhado de valores e crenças entre os colaboradores, que oferece orientação e terreno para o livre agir e pensar. Por conta dos seus efeitos sobre o comportamento dos colaboradores, as organizações cada vez mais reconhecem e assumem a importância da cultura organizacional como fator de diferenciação dos concorrentes. Desta feita, a gestão dos recursos humanos nas organizações passa a exercer uma função estratégica, no sentido de fazer do fator humano um diferencial de competitividade e qualidade, atestando os esforços da qualidade de vida no trabalho. O desafio das empresas é promover condições que atendam as necessidades dos indivíduos. (CHIAVENATO, 1999).

Em suma, de acordo com Silva \& De Marchi (1997), a adoção de programas de qualidade de vida e promoção de saúde proporcionariam ao indivíduo maior motivação, melhor relacionamento, maior estabilidade emocional, melhor autoimagem, maior resistência ao 'stress' e maior motivação. Por outro lado, as empresas seriam beneficiadas com um índice de absenteísmo menor, consequentemente menor rotatividade, menor custo de assistência social, uma força de trabalho mais saudável, maior produtividade e por fim um ambiente de trabalho melhor. 
Dentre os inúmeros desafios que se manifestam ao mundo corporativo dos dias atuais, existem dois elementares. Um destes desafios se apresenta como a capacidade da organização responder à demanda de seus colaboradores em relação a qualidade de vida. O outro se relaciona com a necessidade de uma força de trabalho motivada, saudável e preparada para a alta competitividade e extrema concorrência presente nos dias de hoje (SILVA \& DE MARCHI, 1997).

Programas como a implementação do exercício da meditação, se encaixam perfeitamente neste aspecto, pois tem como propósito prevenir e reduzir os efeitos nocivos da tensão e do estresse emocional através da prática que capacita os praticantes a estabeleceram uma nova maneira de vivenciar as pressões e os desafios do dia-a-dia (JUNIPER, 2016).

A meditação, utiliza métodos de concentração, reflexão e contemplação, constituindo assim um processo de investigação e transformação de certos hábitos mentais e emocionais que regem nossas experiências de vida, invitando seus participantes a explorar de uma perspectiva mais consciente e autentica de viver, desenvolvendo consequentemente uma maior destreza e habilidade para lidar com situações estressantes (ALVES, 2009).

E de acordo com Fernandes (1996), somente atendendo e contemplando as necessidades das pessoas, desenvolvendo-as, maximizando suas potencialidades, é que a organização empresarial também se desenvolverá . De acordo com esse contexto é que surge a importância de se trabalhar com uma tecnologia voltada para as necessidades e para a satisfação dos indivíduos que chamamos de Qualidade de Vida Organizacional.

Tirar proveito de técnicas como a meditação, como por exemplo para reduzir a ansiedade e o estresse, constitui uma notável maneira de manter a mente e o corpo saudáveis, e consequentemente, aumentar a qualidade de vida dos indivíduos (JUNIPER, 2016). 


\section{Métodos e Procedimentos de Coleta e Análise de Dados}

\subsection{Etapas de Coleta de Dados}

O objetivo deste estudo é abordar de forma exploratória como a meditação, a partir dos seus efeitos e benefícios, pode atuar na melhoria da qualidade de vida no trabalho e ser inserida com uma ferramenta no contexto organizacional.

A principal fonte de pesquisa deste estudo foi alcançada através de um estudo de caso, mais especificamente, em uma empresa do setor têxtil que implementou a utilização da prática de meditação atrelada a um programa de qualidade de vida no trabalho. Para uma análise mais aprofundada foram realizados levantamentos bibliográficos acerca do tema abordado. Ademais, foi realizada de forma complementar, uma entrevista técnica com um especialista no assunto, o Venerável Segyu Choepel Rinpoche, monge budista tibetano, pelo fato de ser além de tudo reconhecido mundialmente.

A primeira etapa consistiu em uma pesquisa exploratória, realizada através de diversos encontros com os funcionários da empresa, com o objetivo de estudar a implementação da meditação e identificar os efeitos da prática, relacionando-os com o tema em estudo. Nesta etapa, pretendeu-se a familiarização com a empresa Elenice C. Leitão Confecção \& Beneficiamento ME e seus funcionários, bem como o acompanhamento das aulas de meditação, para que pudesse então compreender as relações na prática integrando-as com a fundamentação teórica deste estudo.

A segunda etapa foi composta de pesquisa descritiva, por meio de análise de questionários enviados aos 25 participantes que concluíram o programa de meditação, com o propósito e a finalidade de registrar e analisar os efeitos e benefícios percebidos bem como os dados relacionados a prática de meditação. Desta forma, este estudo, investigou a percepção dos praticantes de meditação de concentração. Pretendeu-se, portanto, realizar uma análise entre o tema abordado em estudo e a percepção da meditação por parte dos 25 funcionários 
praticantes que responderam a este questionário, representando $45,5 \%$ da população alvo.

\subsection{Fontes de Informação Selecionadas para a Coleta de Dados}

Durante esta etapa da pesquisa, o objetivo foi entrevistar uma personalidade especialista no assunto mundialmente reconhecido, com o objetivo de coletar dados qualitativos visando entender sobre a meditação e como atrelá-la ao mundo contemporâneo bem como o mundo corporativo. A entrevista também contava com o objetivo de conhecer mais sobre a meditação e seu contexto no ocidente. Para que os resultados fossem os melhores possíveis, o entrevistado escolhido foi o venerável Segyu Choepel Rinpoche, monge e médico budista tibetano, brasileiro de nascimento, que vive em São Francisco, Califórnia há mais de vinte anos, onde fundou uma organização chamada Juniper Foundation, e leciona meditação para alguns dos mais destacados e proeminentes executivos de grandes empresas do Vale do Silício, entre outros tantos adeptos.

Durante o acompanhamento do plano de meditação na empresa de confecção de roupas Elenice C. Leitão Confecção \& Beneficiamento ME, foram selecionados para entrevista 3 gestores com mais de 15 anos de trabalho na empresa, buscando identificar as impressões da prática da meditação sobre o ambiente de trabalho.

\subsection{Dados sobre a Pesquisa do Programa de Meditação}

Foi utilizado um questionário (Anexo $\mathrm{A}$ ), que contemplou dados sociodemográficos, tais como sexo, idade, estado civil e escolaridade; bem como informações sobre a prática de meditação, o tempo, a frequência e duração da prática; além de duas questões abertas que perguntavam: "qual foi sua primeira impressão da prática de meditação no trabalho?"; e "em geral, como você acha que a meditação reflete na sua vida?". A partir destas perguntas, foi possível averiguar e investigar a percepção dos praticantes sobre os benefícios e efeitos de sua prática.

\subsection{O Procedimento de Coleta de Dados}

Os dados coletados e obtidos inicialmente através da pesquisa exploratória, dos questionários e da entrevista foram tratados de forma 
qualitativa, já que o roteiro consiste basicamente de perguntas abertas. Desta forma, foram levantados os pontos mais citados pelos participantes bem como pelo especialista entrevistado, e os pontos que mais se relacionam com a fundamentação teórica deste estudo.

Alguns dados obtidos via questionário, foram tratados de forma quantitativa, com o intuito de ilustrar o perfil dos praticantes do programa de meditação.

Os dados foram analisados por meio de analise de conteúdo (BARDIN, 1977), de maneira exploratória, uma vez que se partiu de categorias previamente estabelecidas. O procedimento de análise foi realizado a partir de três etapas: pré-análise, a exploração do material, e o tratamento dos resultados e interpretação. Na investigação dos dados obtidos, efetuou-se a catalogação que percorreu três estágios: I) a extração dos conteúdos em termos ou palavras chaves, transformando-se nos itens específicos de análise; II) a relação dos termos, no qual deu-se preferência a frequência de manifestação dos mesmos; e III) o estabelecimento de classes perante as similitudes e distinções cujo teor apresentava caráter distintos;

Em face dos resultados adquiridos através das respostas, cujo conteúdo constavam substantivos e/ou adjetivos que retravam as impressões e efeitos da meditação, decidiu-se pela medição da frequência de respostas obtidas em cada uma das perguntas abertas realizadas.

\subsection{Limitações do Estudo}

Assim como em toda pesquisa, a presente também possui suas limitações, no entanto, neste estudo, estão basicamente concentradas na etapa da coleta de dados através dos questionários e das entrevistas.

Em relação à amostra da pesquisa, uma limitação relevante se refere ao fato de que a maioria dos participantes eram do sexo feminino, por se tratar de uma confecção de roupas.

Ao que se refere aos questionários enviados aos funcionários e praticantes da meditação, como limitação pode-se referir o fato de o tamanho da amostra ser consideravelmente pequeno, o qual possivelmente interferiu no poder do estudo. Outra limitação se dá por conta dos praticantes apresentarem um baixo grau de escolaridade, apesar do questionário ser bastante simples em sua concepção, composto somente de duas páginas, com apenas duas simples perguntas abertas e subjetivas. 
Ao que se refere as perguntas realizadas de forma aberta, apesar de não restringir qualquer informação, são mais subjetivas em sua coleta, tratamento e análise. Pode ocorrer, deste modo, algum equívoco momentâneo, especialmente se o pesquisador for inexperiente.

Por tratar-se de entrevistas informais em tempo real, o pesquisador pode se aprofundar no tema assim como sair do roteiro caso o assunto de interesse apareça. Se fosse utilizado qualquer método do qual o pesquisador não participa enquanto obtém as respostas, como por exemplo enviar as perguntas previamente via correio eletrônico, o assunto poderia ficar limitado para as perguntas feitas anteriormente. De certo modo isto eliminaria a preciosa oportunidade do entrevistado falar o que realmente sente ou acha, bem como o que Ihe vier a cabeça, por ter de pensar demais na resposta ao elaborá-la e escrevê-la.

Outra limitação identificada durante a etapa de entrevista com o especialista, pode ser na utilização do gravador, possivelmente um inibidor para quem é entrevistado. Como neste caso a utilização da tecnologia foi previamente acordada e consentida, não é preciso levar em consideração este ponto. 


\section{Descrição e Análise dos Resultados}

Este capítulo apresenta e discute os principais resultados alcançados, evidencia a análise, discute suas implicações e produz sugestões sobre o estudo previamente selecionado.

Está organizado em três seções, de acordo com as etapas de pesquisa. A primeira seção apresenta e descreve os dados obtidos com o programa de 8 semanas de prática de meditação na empresa Elenice C. Leitão Confecção \& Beneficiamento ME. A segunda seção apresenta e analisa as entrevistas informais realizadas com três dos principais gestores da Elenice C. Leitão, e descreve as opiniões e percepções dos principais gestores da empresa em relação ao programa de meditação. A terceira se trata da apresentação e análise dos principais aspectos da meditação obtidos através de entrevista com o especialista do tema em questão, o monge budista tibetano, venerável Segyu Choepel Rinpoche, relacionando as respostas com a conceituação teórica desse estudo.

\subsection{Resultados dos Questionários}

\subsubsection{A Empresa}

A empresa Elenice C. Leitão Confecção \& Beneficiamento ME, está há mais de 15 anos no mercado de confecção de roupas e acessórios para marcas e grifes brasileiras. Situada no pólo têxtil da cidade do Rio de Janeiro, possui atualmente 73 funcionários, a maior parte (aproximadamente $70 \%$ ) com mais de 10 anos de casa. A empresa produz majoritariamente peças de vestuário feminino, e elabora desde a concepção do desenho das roupas junto aos seus clientes, como também se responsabiliza pelo corte e caimento, costura, estampagem e etiquetagem das roupas. Em média produz cerca de 20.000 peças por mês, e possui um faturamento anual de $R \$ 1.800 .000,00$. 


\subsubsection{O Programa de Meditação}

De todos os 55 funcionários que participaram do programa de meditação, apenas 25 completaram as 8 semanas do programa de meditação na empresa. Estes foram entrevistados no fim do programa com a finalidade de conhecer suas percepções e opiniões sobre a prática de meditação. Adicionalmente, a experiência subjetiva dos meditadores acerca dos efeitos de sua prática também foi explorada. O questionário foi dividido em duas partes, sendo a primeira com dados sociodemográficos, e a segunda parte com três perguntas subjetivas, sendo duas delas abertas.

O programa de meditação foi realizado, durante os meses de Março, Abril e Maio de 2016. Em seguida foi realizada a pesquisa exploratória, com o objetivo de estudar os efeitos do programa de 8 semanas de meditação voltado para os funcionários da organização.

No que tange a participação dos funcionários e colaboradores, vale ressaltar que o programa de meditação oferecido pela empresa aos funcionários era facultativo, ou seja, participava aquele funcionário que de livre e espontânea vontade demonstrasse interesse. Foi combinado previamente, que de forma alguma alguém seria obrigado a comparecer as sessões, e muito menos ser punido pelo possível não comparecimento. O horário da prática, foi previamente debatido com os funcionários e gestores, sendo estabelecido que a melhor opção seria ministrar as aulas antes do período do almoço, às 11:30 da manhã.

Durante o período, do dia 22 de Março até o dia 19 de Maio de 2016, foram realizadas, todas terças e quintas-feiras, com exceção de feriados, as sessões de meditação no refeitório da empresa. No total foram ministradas 17 sessões de 30 minutos de duração.

O método de meditação abordado foi o da meditação concentrativa do Método Arte de Meditar: Na Onda da Vida (Anexo C). Neste método específico, após o momento de adequação e preparação da postura de meditação, se estabelece o objeto de concentração e foco, neste caso específico o objeto em questão é a respiração. Durante cerca de 21 minutos, o praticante observa atentamente e se concentra em sua própria respiração. O facilitador e instrutor, neste caso o próprio pesquisador, durante cada sessão guiou os participantes a medida que os mesmos praticavam a meditação.

No total, dos 73 funcionários da empresa, 55 deles participaram deste estudo praticando a técnica de meditação concentrativa, do tipo passivo, sentada e guiada - este número equivale a $75,3 \%$ do quadro de colaboradores 
da empresa - com uma idade média de 42,6 anos, dos quais $92,7 \%$ pertenciam ao sexo feminino, $72,7 \%$ se declararam solteiros, $94,6 \%$ haviam cursado ensino fundamental e $41,8 \%$ o ensino médio. Quase todos os praticantes $(96,4 \%)$, com exceção da sócia fundadora da empresa e de uma das gerentes, consideraram nunca haver realizado qualquer prática de meditação (Tabela1).

Tabela 1. Distrubuição das Variáveis Sociodemográficas e Tempo de Meditação Entre os Participantes.

\begin{tabular}{lcr}
\hline Variáveis & $f$ & $\%$ \\
\hline Sexo & & \\
$\quad$ Feminino & 51 & $92,7 \%$ \\
$\quad$ Masculino & 4 & $7,3 \%$ \\
Idade (anos) & & \\
$20-29$ & 4 & $7,3 \%$ \\
$30-39$ & 18 & $32,7 \%$ \\
$40-49$ & 12 & $38,2 \%$ \\
$\geq 50$ & & $21,8 \%$ \\
Estado Civil & & \\
Solteiro/sem companheiro & 40 & $60 \%$ \\
Casado/com companheiro & 15 & $40 \%$ \\
Escolaridade (nível) & & \\
Fundamental & 29 & $52,8 \%$ \\
Médio & 23 & $41,8 \%$ \\
Superior & 3 & $5,4 \%$ \\
Tempo de Meditação & & \\
Sem Experiência & 53 & $96,4 \%$ \\
Iniciante (até 12 meses) & 1 & $1,8 \%$ \\
Intermediário (13-36 meses) & 1 & $1,8 \%$ \\
Avançado (. 36 meses) & 0 & $0 \%$ \\
\hline TOTAL & 55 & \\
\hline
\end{tabular}

Fonte: (O Autor) 
Os praticantes, cujo tempo mínimo indicado de prática de meditação deveria ser de 2 (dois) meses, com 21 minutos de duração e uma frequência de duas vezes na semana, frequentavam as sessões de meditação no refeitório da empresa, antes do horário de almoço, guiado pelo próprio pesquisador.

Após o término do programa de meditação, foi distribuído um questionário para cada um dos participantes que concluíram as 8 semanas de prática meditativa. O questionário contemplava tanto os dados sociodemográficos (quantitativos) mencionados acima, tais como sexo, idade, estado civil e escolaridade, bem como informações sobre a prática de meditação (o tempo, a frequência e duração da prática); além de duas questões abertas (qualitativas) que perguntavam: "qual foi sua primeira impressão da prática de meditação no trabalho?"; e "em geral, como você acha que a meditação reflete na sua vida?". A partir destas perguntas, foi possível averiguar e investigar a percepção dos praticantes sobre os benefícios e efeitos de sua prática.

Verificou-se com o intuito de ilustrar a pesquisa, somente as respostas dos 25 funcionários que concluíram as 8 semanas do programa de meditação, número equivalente a $45,5 \%$ do total que começou (Tabela 2 ).

Tabela 2. Distrubuição das Variáveis Sociodemográficas e Tempo de Meditação Entre os Participantes Que Concluíra o Programa de Meditação.

\begin{tabular}{lrr}
\hline Variáveis & $f$ & $\%$ \\
\hline Sexo & & \\
$\quad$ Feminino & 25 & $100 \%$ \\
$\quad$ Masculino & 0 & $0 \%$ \\
Idade (anos) & 2 & \\
$20-29$ & 12 & $48 \%$ \\
$30-39$ & 7 & $28 \%$ \\
$40-49$ & 4 & $16 \%$ \\
$\geq 50$ & & \\
Estado Civil & 15 & $60 \%$ \\
Solteiro/sem companheiro & 10 & $40 \%$ \\
Casado/com companheiro & & \\
Escolaridade (nível) & 11 & $44 \%$ \\
Fundamental & 11 & $44 \%$ \\
Médio & 3 & $12 \%$ \\
Superior & & \\
Tempo de Meditação & 23 & $96 \%$ \\
Sem Experiência & 1 & $4 \%$ \\
Iniciante (até 12 meses) & 1 & $12 \%$ \\
Intermediário (13-36 meses) & 0 & $0 \%$ \\
Avançado (. 36 meses) & & \\
\hline TOTAL & 25 &
\end{tabular}

Fonte: (O Autor) 
Destes 25 participantes, vale ressaltar alguns dados relevantes obtidos via questionário:

$\rightarrow 100 \%$ do sexo feminino;

$\rightarrow 60 \%$ solteiro(a) ou sem companheiro(a);

$\rightarrow 44 \%$ cursou o ensino médio;

$\rightarrow 96 \%$ nunca havia meditado;

$\rightarrow 39,3$ anos (idade média).

Figura 1. Infográfico I referente à Tabela 1 e 2

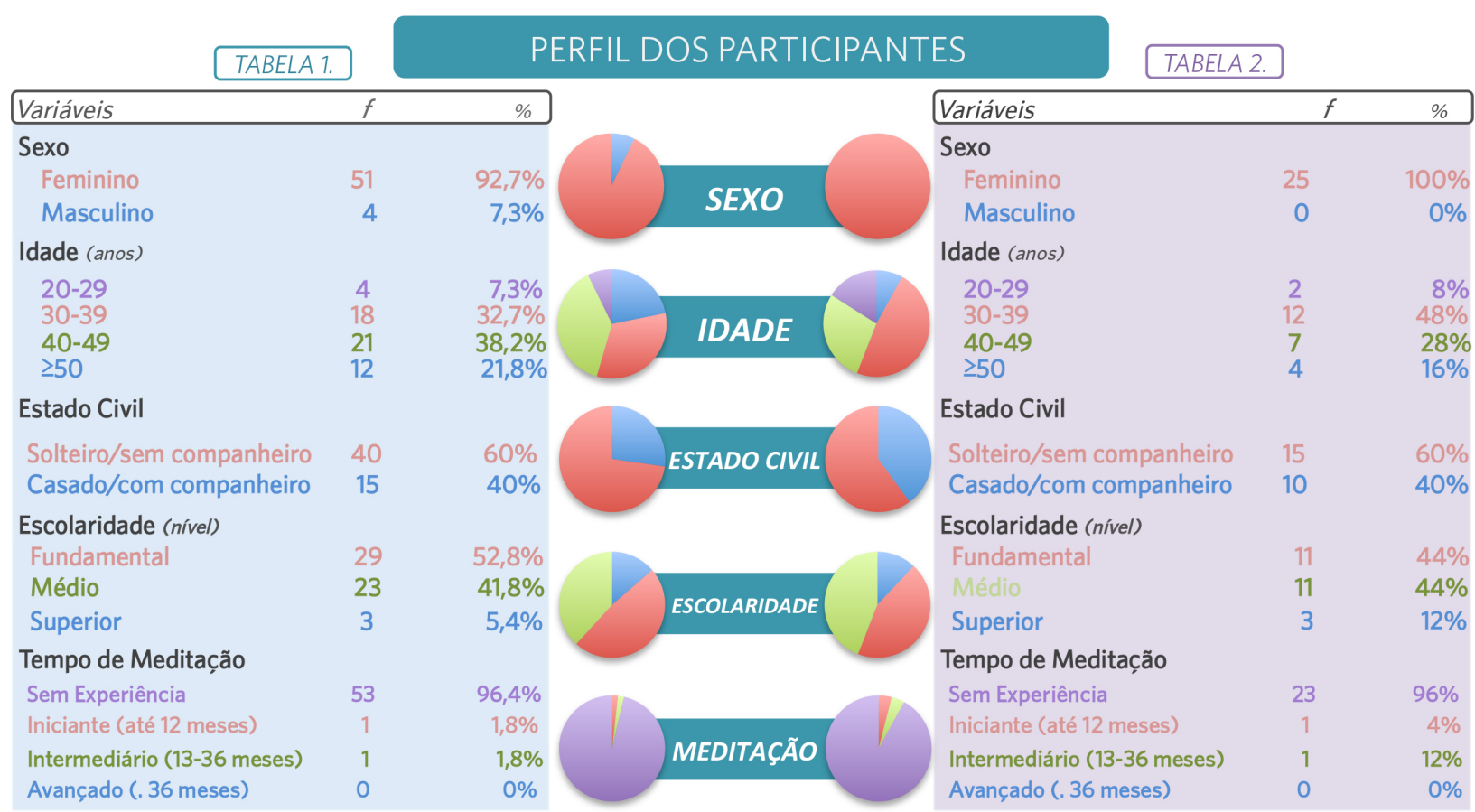

Fonte: (O Autor) 
Figura 2. Infográfico II referente as Tabela 1 e 2

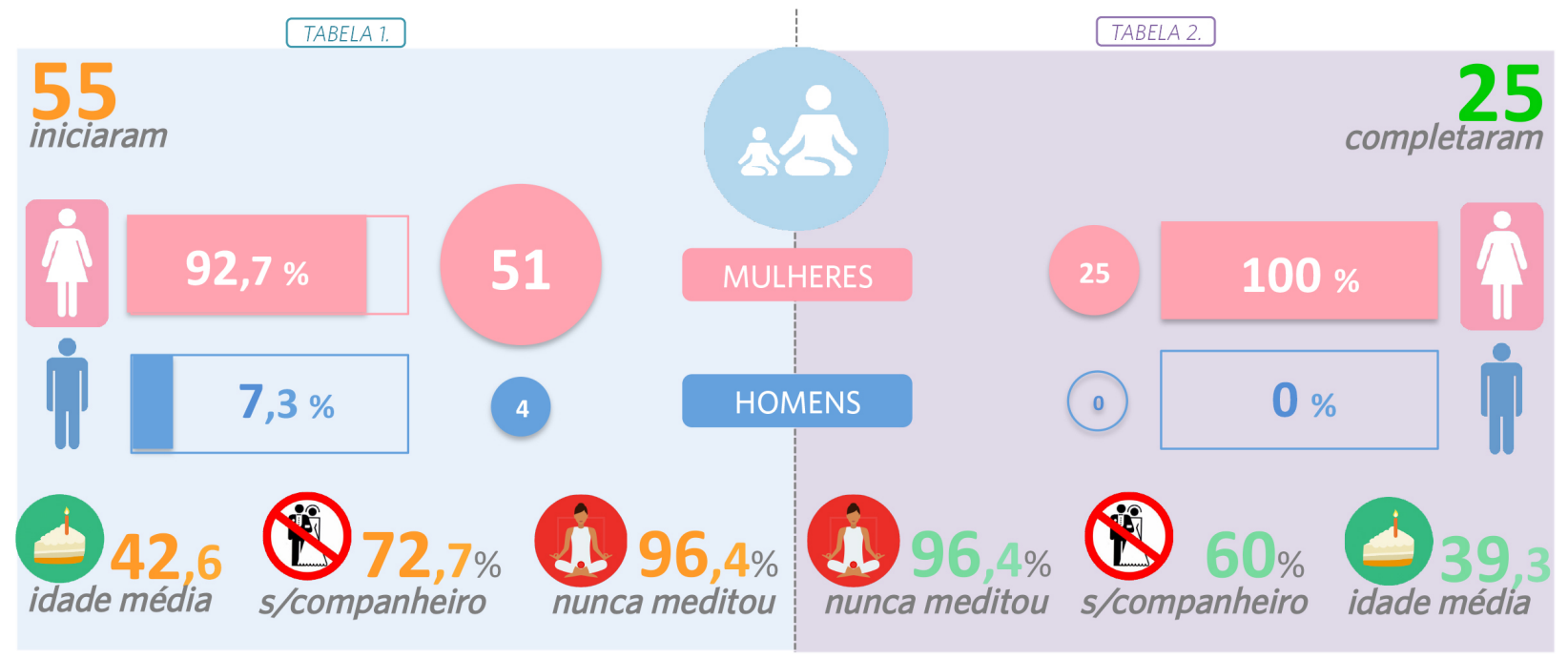

Fonte: (O Autor)

Quanto às questões abertas do questionário (anexo A), foram levantadas dezenas de respostas, com aproximadamente 176 termos ou expressões, os quais foram selecionados de acordo com sua frequência (Tabela 3, 4 e 5).

Tabela 3. Percentuais de Termos mais Frequentes Respondidos Pelos Participantes que Concluíram o Programa de Meditação na Primeira Pergunta Aberta: "Qual foi sua primeira impressão da prática de meditação no trabalho?".

\section{PERCENTUAL DE TERMOS MAIS FREQUENTES}

\begin{tabular}{|c|c|c|c|}
\hline & Termos & $f$ & $\%$ \\
\hline$=$ & "algo diferente" & 1 & \\
\hline & "aprendizado" & 1 & \\
\hline ̊ి & "bem-estar" & 5 & \\
\hline 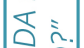 & "calma" & 6 & \\
\hline $0 \Omega$ & "desconfiada" & 1 & \\
\hline 需 & "energia positiva" & 3 & \\
\hline 虫 & "gratificante" & 2 & \\
\hline$\sum$ & "leveza" & 1 & \\
\hline$\leqslant$ & "mais conectada com deus" & 1 & \\
\hline is & "maior disposição" & 4 & \\
\hline 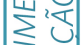 & "mais concentrada" & 4 & \\
\hline $\bar{\alpha} \frac{1}{\alpha}$ & "mais confiança" & 2 & \\
\hline$\leqslant \overline{0}$ & "mais controle das emoções" & 3 & \\
\hline$\vec{s}=$ & "mais espaço" & 1 & \\
\hline$\leftleftarrows 5$ & "mais silêncio" & 1 & \\
\hline I0 & "melhora na relação com os colegas" & 4 & \\
\hline 11 & "melhora no ambiente de trabalho" & 3 & \\
\hline & "muito bom" & 3 & \\
\hline & "passei a refletir melhor" & 3 & \\
\hline
\end{tabular}

\begin{tabular}{llr}
\hline Termos & $f$ & $\%$ \\
\hline "paz" & 5 & $7,6 \%$ \\
"relaxar" & 6 & $9,1 \%$ \\
"resultado extremamente satisfatório" & 1 & $1,5 \%$ \\
"tirou a carga negativa" & 1 & $1,5 \%$ \\
"tranquilidade" & 4 & $6,1 \%$ \\
& & \\
& & \\
Total de Termos & 66 & \\
\end{tabular}

Fonte: (O Autor) 
Tabela 4. Percentuais de Expressões ou Termos mais Frequentes Respondidos Pelos Participantes que Concluíram o Programa de Meditação na Segunda Pergunta Aberta: "Em geral, como você acha que a meditação reflete na sua vida?".

\section{PERCENTUAL DE TERMOS MAIS FREQUENTES}

\begin{tabular}{|c|c|c|c|c|c|c|}
\hline & Termos & $f$ & $\%$ & Termos & $f$ & $\%$ \\
\hline \multirow{19}{*}{ 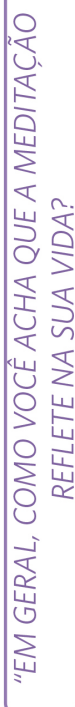 } & "aceitação" & 2 & $1,8 \%$ & "maior valor" & 2 & $1,8 \%$ \\
\hline & "ajuda a tomar decisões" & 2 & $1,8 \%$ & "mais atenção" & 4 & $3,6 \%$ \\
\hline & "ajudou a me conhecer" & 7 & $6,4 \%$ & "mais consciência do próximo" & 1 & $0,9 \%$ \\
\hline & "alívio nas crise alérgicas" & 1 & $0,9 \%$ & "mais foco" & 2 & $1,8 \%$ \\
\hline & "mais ânimo" & 2 & $1,8 \%$ & "mais paciência" & 5 & $4,5 \%$ \\
\hline & "aprendi a me controlar" & 3 & $2,7 \%$ & "mais tranquilidade" & 4 & $3,6 \%$ \\
\hline & "aprendi a respirar melhor" & 6 & $5,5 \%$ & "me traz sensação de paz" & 5 & $4,5 \%$ \\
\hline & "bastante" & 4 & $3,6 \%$ & "melhora no sono" & 4 & $3,6 \%$ \\
\hline & "bem-aventurança" & 1 & $0,9 \%$ & "melhora o desempenho" & 1 & $0,9 \%$ \\
\hline & "calma" & 8 & $7,3 \%$ & "ouvir melhor" & 1 & $0,9 \%$ \\
\hline & "clareza" & 1 & $0,9 \%$ & "qualidade de vida" & 3 & $2,7 \%$ \\
\hline & "concentração" & 5 & $4,5 \%$ & "reflete pouco" & 1 & $0,9 \%$ \\
\hline & "de grande importância" & 2 & $4,5 \%$ & "relaxamento" & 5 & $4,5 \%$ \\
\hline & "energia positiva" & 3 & $1,8 \%$ & "sabedoria" & 2 & $1,8 \%$ \\
\hline & "equilíbrio" & 1 & $0,9 \%$ & "satisfação" & 1 & $0,9 \%$ \\
\hline & "fonte de prazer" & 2 & $1,8 \%$ & "serenidade" & 4 & $3,6 \%$ \\
\hline & "força" & 1 & $0,9 \%$ & & & \\
\hline & "leveza" & 2 & $1,8 \%$ & & & \\
\hline & "maior bem-estar" & 7 & $6,4 \%$ & Total de Termos & 110 & \\
\hline
\end{tabular}

Fonte: (O Autor)

Tabela 5. Percentuais de Frequência das Respostas obtidas (por Categoria)

\section{PERCENTUAL DE FREQUENACIA DOS TERMOS (POR CATEGORIA)}

\begin{tabular}{|c|c|c|c|c|c|}
\hline Categorias & $f$ & $\%$ & Categorias & $f$ & $\%$ \\
\hline FISIOLÓGICO & 42 & $23,8 \%$ & EMOCIONAL & 66 & $37,5 \%$ \\
\hline "alívio nas crises alérgicas" & 1 & $2,4 \%$ & "bem-estar" & 12 & $18,2 \%$ \\
\hline "aprendi a respirar melhor" & 6 & $14,3 \%$ & "calma" & 14 & $21,2 \%$ \\
\hline "maior disposição/ânimo" & 6 & $14,3 \%$ & "controle" & 6 & $9,1 \%$ \\
\hline "melhora no sono" & 4 & $9,5 \%$ & "equilíbrio" & 6 & $9,1 \%$ \\
\hline "relaxamento" & 11 & $26,2 \%$ & "paz" & 10 & $15,2 \%$ \\
\hline & & & "serenidade" & 4 & $6,1 \%$ \\
\hline Outras respostas & 14 & $33,3 \%$ & "tranquilidade" & 8 & $12,1 \%$ \\
\hline MENTAL & 39 & $22,2 \%$ & Outras respostas & 6 & $9,1 \%$ \\
\hline "ajuda na tomada de decisões" & 2 & $5,1 \%$ & OUTRAS & 29 & $16,5 \%$ \\
\hline "ajudou a me conhecer" & 7 & $17,9 \%$ & & & \\
\hline "concentração" & 9 & $23,1 \%$ & & & \\
\hline "mais atenção/foco" & 6 & $15,4 \%$ & & & \\
\hline "mais consciência do próximo" & 1 & $2,6 \%$ & & & \\
\hline "paciência" & 5 & $12,8 \%$ & & & \\
\hline Outras respostas & 9 & $23,1 \%$ & Total de respostas & 176 & $100 \%$ \\
\hline
\end{tabular}

Fonte: (O Autor) 
A respeito da primeira pergunta aberta realizada, "qual foi a sua primeira impressão da prática de meditação no trabalho?", verifica-se através da Tabela 3 as expressões e os termos mais recorrentes encontrados nas respostas dos praticantes do programa de meditação: "calma", "relaxar", "paz", "bem-estar", "equilíbrio", "mais concentrada", "maior disposição", "melhora na relação com os colegas" e "tranquilidade".

Figura 3. Infográfico referente a Tabela 3

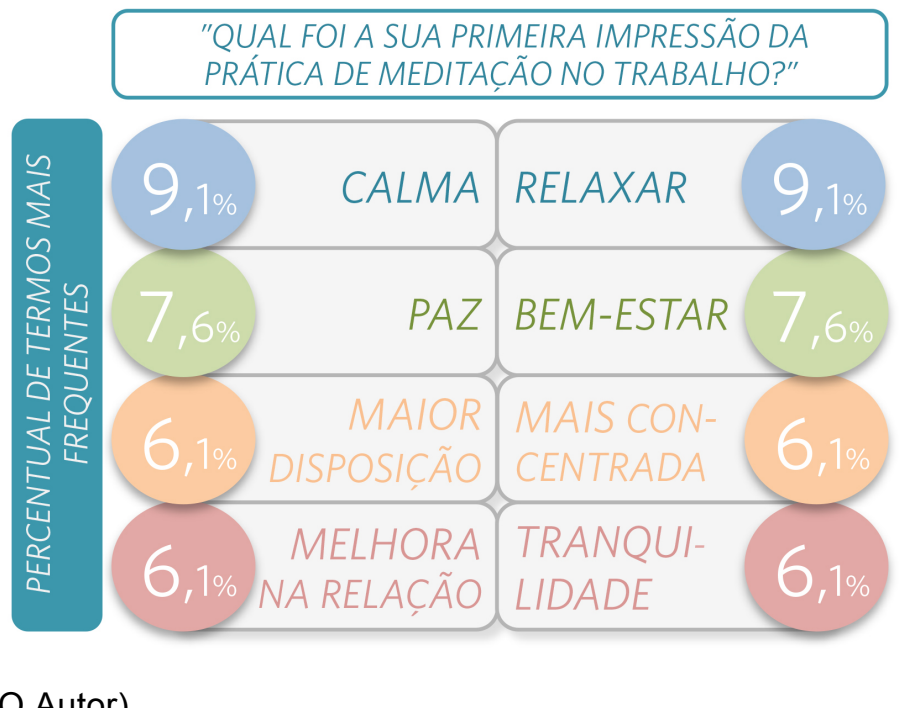

Fonte: (O Autor)

Quanto a segunda pergunta aberta, "em geral, como você acha que a meditação reflete na sua vida?", de acordo com a Tabela 4, as respostas mais frequentes se relacionavam aos seguintes termos e expressões: "calma", "ajudou a me conhecer", "maior bem-estar", "aprendi a respirar melhor", "equilíbrio", "me traz sensação de paz", "concentração", "mais paciência" e "relaxamento". 
Figura 4. Infográfico referente a Tabela 4

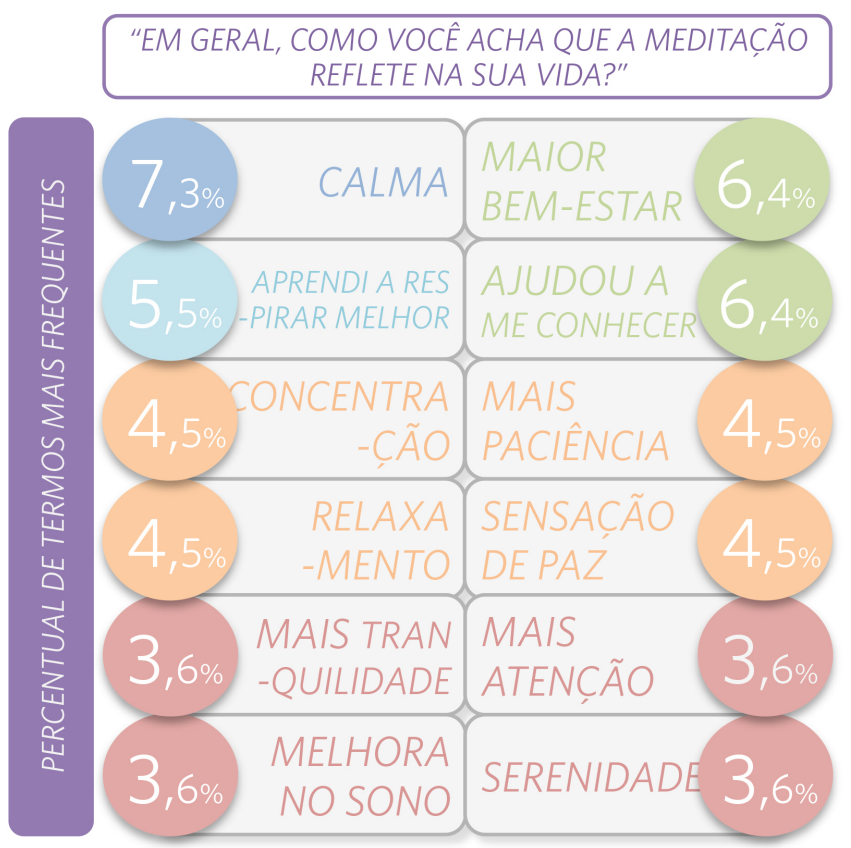

Fonte: (O Autor)

Ao todo foram verificadas cerca de 59 tipos diferentes de expressões ou termos mencionados nas respostas obtidas através dos questionários. Com o intuito de detalhar tais dados, as respostas foram classificadas em três tipos de categoria: fisiológico, mental e emocional, expostas a seguir: I) a categoria fisiológico abrangeu aspectos como melhora no sono, alívio nas crises alérgicas, respirar melhor, maior disposição, relaxamento, entre outros; II) a categoria mental incluiu respostas referentes a fatores mentais provenientes da prática de meditação como mais atenção, concentração, clareza, sabedoria, mais consciência do próximo, ajuda na tomada de decisão, etc.; III) a categoria emocional envolveu respostas de caráter afetivo, como sentimentos de serenidade, bem-estar, calma, paz, tranquilidade, equilíbrio, etc. (Tabela 5). 
Figura 5. Infográfico referente a Tabela 5

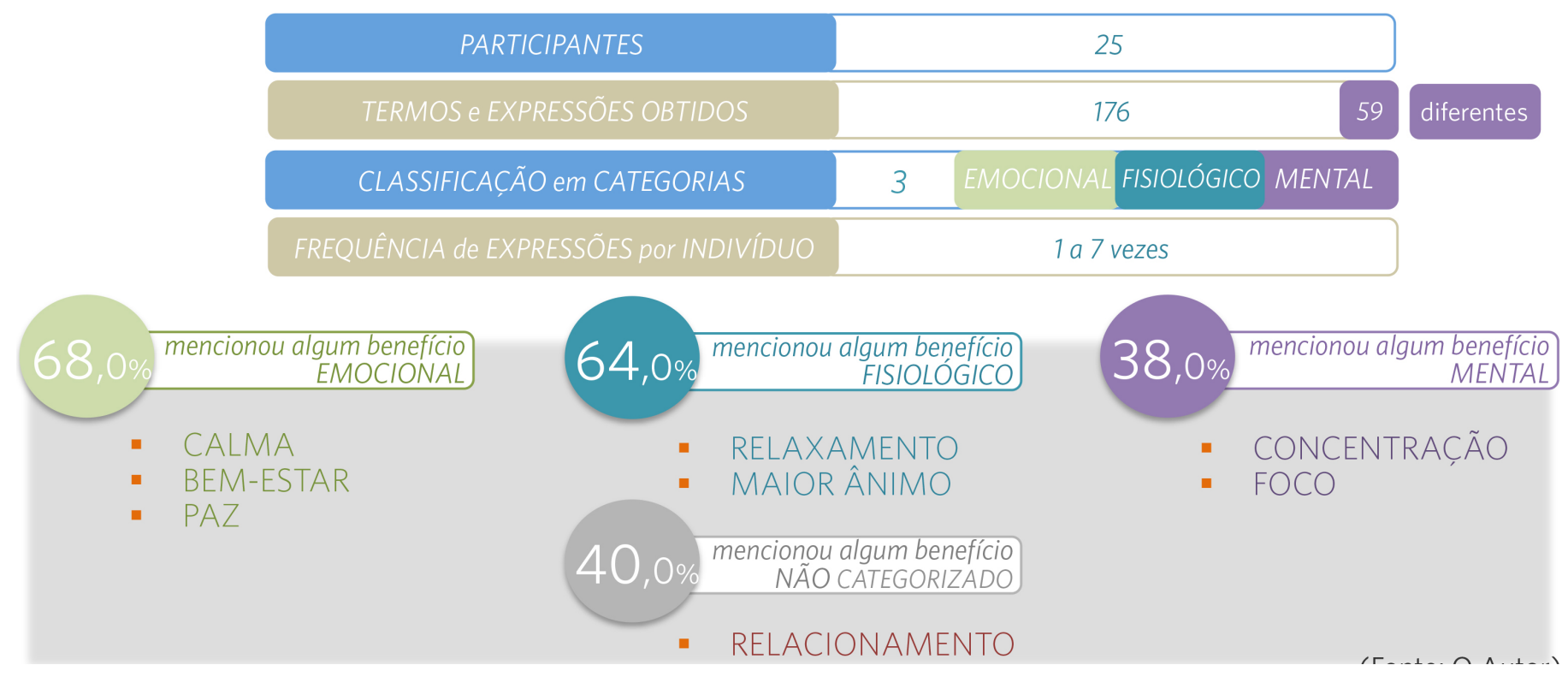

Fonte: (O Autor)

De todo modo, é oportuno salientar que as análises abrangeram o número absoluto de termos respondidos e não o total de indivíduos, tendo em vista que não havia um número limite de termos que cada integrante do programa podia declarar em suas respostas. Observou-se que a frequência das expressões utilizadas por um indivíduo em uma mesma categoria oscilou de uma vez a sete vezes. Uma parte considerável dos participantes mencionou ao menos uma vez certo tipo de benefício emocional (68\%) e fisiológico (64\%). No entanto apenas $38 \%$ indicou algum benefício mental e $40 \%$ relataram algum tipo de benefício não categorizado.

Os resultados obtidos parecem confirmar o que afirmam os autores Davidson \& Goleman (1976) e Kristeller \& Hallet (1999), a respeito dos efeitos de um programa de meditação de concentração durante um período de oito semanas.

Ao que tudo indica a pesquisa, diversos foram os benefícios e efeitos percebidos da prática meditativa, a maioria de caráter fisiológico, mental e emocional (KHALSA, 2001).

Tais efeitos e benefícios mencionados nos parágrafos acima sugerem a meditação como uma prática que consegue efetivamente criar ambientes mais calmos entre os praticantes pois eles passam a controlar melhor suas emoções e gerir melhor o estresse no ambiente no qual estão inseridos e no local de trabalho. A meditação assim confirma que pode ser uma das soluções para a 
redução do valor que a gestão de conflitos tem custado às empresas, tendo em consideração a diminuição do rendimento e performance atrelado a tais conflitos (González, 2009).

De uma maneira geral, pode-se determinar que a experiência proveniente da prática de meditação se reflete de inúmeras formas, com a predominância de efeitos e benefícios cognitivos, físicos e emocionais, e que o ato de meditar se constitui com uma ferramenta para o desenvolvimento psicológico saudável. As entrevistas realizadas nesta pesquisa apontam que muitos praticantes mencionaram entre outros fatores, uma sensação de calma, maio concentração, melhora na disposição e por fim o reflexo disso no ambiente de trabalho, corroborando para o que os autores Duerr (2004) e Menezes (2009) afirmam.

Os resultados alcançados apontam para a tendência da meditação influenciar positivamente na qualidade de vida do trabalhador, uma vez que promove maior equilíbrio físico, psíquico, social, além de obter uma vida mais satisfatória e proporcionar um maior bem estar. Tirar proveito de técnicas como a meditação, como por exemplo para reduzir a ansiedade e o estresse, constitui uma notável maneira de manter a mente e o corpo saudáveis, e consequentemente, aumentar a qualidade de vida dos indivíduos (JUNIPER, 2016).

Ademais, a partir das evidências observadas na pesquisa, averigua-se a consonância entre a prática de meditação bem como seus efeitos com as diretrizes da qualidade de vida no trabalho e seus benefícios. Conforme afirma Fernandes (1996) são inúmeros os benefícios provenientes da Qualidade de Vida no Trabalho (QVT), dentre eles sobressaem-se o desenvolvimento das capacidades humanas, melhoria no ambiente de trabalho, promoção da saúde e maior motivação.

\subsubsection{Resultado das Entrevistas com os Gestores}

Após a coleta de dados sobre o programa de meditação in company, três funcionários chave da empresa foram entrevistados a fim de conceder suas opiniões, impressões e percepções não apenas sobre o programa de meditação em si, mas também sobre os efeitos gerados no ambiente da organização. As entrevistas forma divididas em quatro partes distintas, sendo a primeira uma introdução ao perfil do entrevistado, a segunda em relação a implementação do programa de meditação, a terceira se refere a uma sucinta avaliação dos 
resultados do programa, e por fim, a quarta e a última parte foi idealizada como uma tentativa de entender o que os entrevistados apostam para o futuro do programa de meditação na empresa.

A primeira entrevista foi realizada com a gestora 1, fundadora, sócia e proprietária da empresa, que atualmente também é responsável pela área desenvolvimento e criação. A segunda entrevista foi feita com a gestora 2, gerente de produção, que está na organização desde 2003, quando entrou como assistente de controle de produção. Finalmente, a terceira e última entrevista, foi realizada com a gestora 3 , supervisora da área de costura, que faz parte da equipe da empresa desde 2003. Nos parágrafos a seguir, as três entrevistas serão transcritas, apresentando primeiramente a pergunta, seguida das respostas, e por fim a análise do conteúdo de cada uma delas.

As entrevistas começaram com uma pergunta visando saber a respeito da opinião de cada uma das entrevistadas sobre o ambiente de trabalho antes, durante e depois do programa de meditação. A gestora 1, como proprietária e comandante da empresa, conta que, a primeira medida os funcionários desconfiaram do programa de meditação mas encararam a oportunidade com entusiasmo. A medida que o programa foi se desenrolando, notou uma maior harmonia entre os funcionários da área da Costura e do PCP (área voltada ao planejamento e controle de produção), principalmente no que tange a comunicação entre as partes. Ao fim do programa, observou mudanças consideráveis no setor da costura, onde segundo ela, as costureiras passaram a ter mais atenção, e consequentemente na sua percepção alguns erros comuns foram mitigados. Segundo a gestora 1 relata, uma aura diferente se instaurou na confecção, pois no lugar de pessoas que muitas vezes trabalhavam de 'cara amarrada' surgiu um sorriso ou outro.

As afirmações observadas no parágrafo precedente corroboram com a tese de Gonzáles (2009), que a meditação se caracteriza como uma prática que consegue efetivamente criar ambientes mais calmos entre os praticantes pois eles passam a controlar melhor suas emoções e gerir melhor o estresse no ambiente no qual estão inseridos e no local de trabalho.

A gestora 2, como gerente de produção, conta que antes da inserção da meditação na empresa, os funcionários quando cobrados a respeito de determinada tarefa reagiam de maneira negativa, mas que durante o decorrer das aulas muitos deles passaram a praticar, nos momentos de tensão, os 
exercícios de meditação. Assim, notou uma melhora na comunicação interpessoal e no rendimento dos funcionários, pois passaram a se dedicar ao trabalho de maneira mais consciente, coerente e solicita. Depois que o programa de 8 semanas deu-se por acabado, a gestora 2 observou que aqueles funcionários que praticaram a meditação até o fim do período estavam mais calmos e atentos. Ela mesmo diz que a empresa era uma antes da prática de meditação, e que agora parece que ela trabalha em outro lugar. Relatou que na sua opinião, a meditação traz calma e vigor inigualável, e que passou a recomendar a meditação para suas amigas fora do trabalho.

As respostas contidas no parágrafo anterior confirmam a tese de que o colaborador, quando motivado, tem maior disposição e capacidade para desempenhar suas funções e atividades de trabalho (Chiavenato, 1999). Ademais, de acordo com Jain et al. (2007) verifica-se que houve um aumento do relaxamento físico e dos afetos positivos. De maneira complementar, observa-se a meditação como uma prática que auxilia na melhora de qualidade de vida dos indivíduos (JUNIPER, 2016).

Como boa parte dos praticantes assíduos do programa era composto por funcionários do setor de Costura, a gestora 3, supervisora da área, diz que antes do programa, o ambiente do setor era altamente beligerante, e que além disso muitas funcionárias não se respeitavam. À respeito do programa de meditação, ela relata que muitas funcionárias atrelavam a meditação a alguma religião e desconfiavam da prática, mas que a maioria resolveu assim mesmo experimentar. No decorrer das primeiras sessões de meditação, notou um entusiasmo incomum nas costureiras meditadoras. Diz que o entusiasmo era tamanho que as costureiras que não tinham praticado resolveram praticar para saber se era verdade. A gestora 3, notou uma maior atenção no desempenho das tarefas, maior paciência e disciplina na hora de receber e efetuar as ordens. Após a realização do programa, identificou que as funcionárias praticantes e não praticantes estavam mais calmas e relaxadas no trabalho, e que o ambiente de trabalho do setor de costura melhorou mas que ainda poderia melhorar mais. $\mathrm{Na}$ sua opinião, a meditação foi muito eficiente e produtiva, e que ela torce para empresa continuar com o programa.

Assim, com o relato da gestora 3, a respeito de como suas colegas de trabalho se sentiam após meditarem, pode-se concluir que a meditação caminha lado a lado com o conceito de qualidade de vida, pois segundo diz Chiavenato (1999), a qualidade de vida está diretamente ligada a maximização do potencial 
humano, e isto depende da maneira como as pessoas se sentem trabalhando na organização. A experiência com a meditação exerceu esse papel primordial e essencial na realização das atividades de trabalho, uma vez que influenciou diretamente a qualidade de vida e o comportamento do funcionário.

Figura 6. Infográfico I referente a Entrevista com Gestores

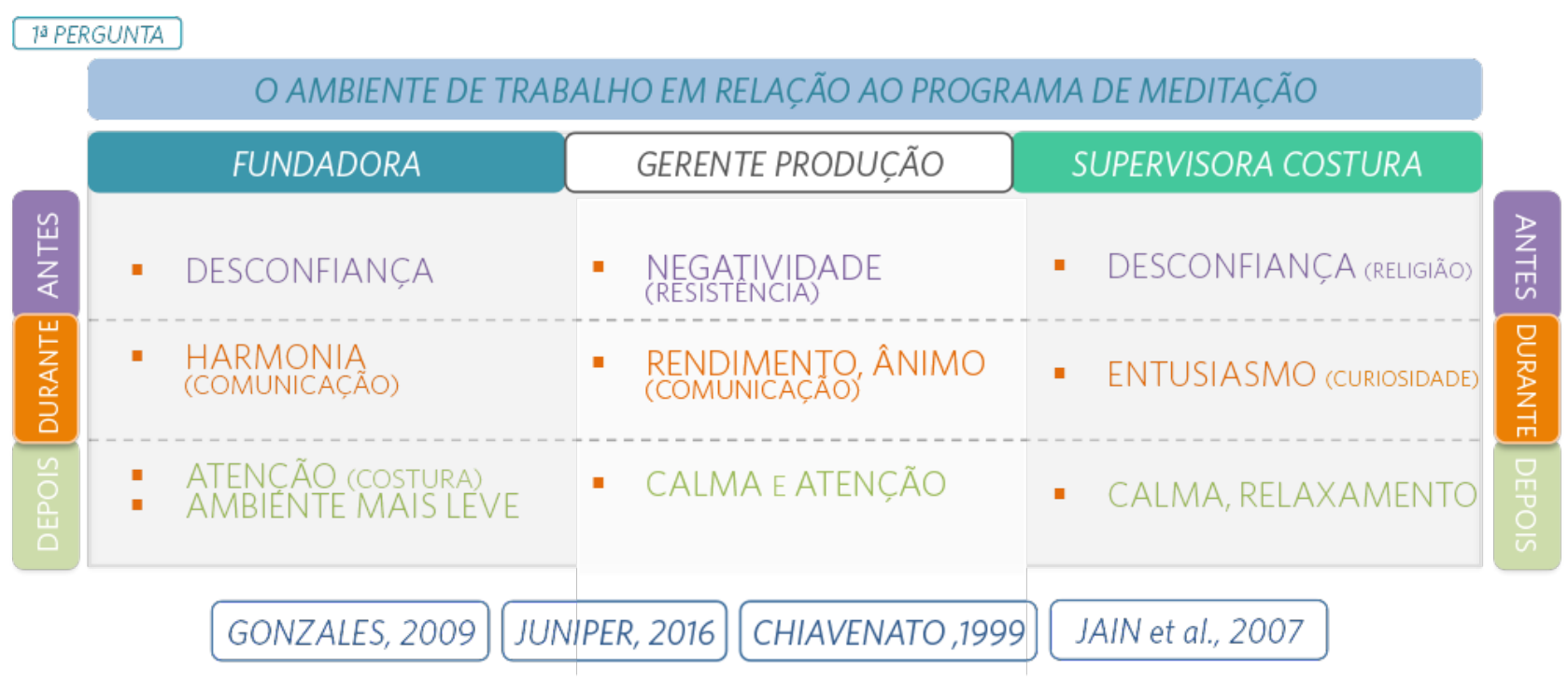

Fonte: (O Autor)

A segunda pergunta discorre sobre a impressão e a influência que a prática de meditação teve no dia-a-dia da empresa. De início, a gestora 1 diz que a prática de concentração atribuída a meditação ajudou-a na tomada de decisões e na solução de conflitos. Ela aponta que já meditava antes, mas que ao meditar no trabalho conseguiu atrelar a meditação as tarefas profissionais e assim associá-la ao seu desempenho na organização. Diz que foi mágico, que meditar no trabalho junto dos funcionários trouxe uma maior proximidade com o grupo, e consequentemente uma harmonia nunca antes vista. Outra questão apontada pela gestora 1 , foi que o relaxamento proveniente da prática ajudou-a controlar melhor sua ansiedade bem como suas emoções. A gestora 1 acredita que o programa superou suas expectativas.

Por sua vez, a gestora 2, diz que não esperava por benefício algum mas relata que a meditação ajudou-a em casa, no relacionamento com o marido e com seu filho. Ela conta que chegava menos cansada em casa, e podia dar mais atenção aos seus familiares, diz que isso fez uma grande diferença, pois para ela o trabalho influencia diretamente na sua vida pessoal e vice-versa. De 
acordo com a gestora 2, com a prática frequente ela conseguiu dormir melhor e acordar descansada, que ficou mais tranquila mas mesmo assim existem momentos em que percebe que ainda fica nervosa e tensa. Diz que a meditação veio para ficar na sua vida, e que se antes argumentava que não tinha tempo para meditar, agora ela medita para aproveitar melhor o tempo.

Segundo a gestora 3 , a meditação trouxe um bem-estar similar ao momento em que reza e faz sua oração. Para ela, atrelar este estado de calma e paz no ambiente de trabalho é altamente benéfico e preciso. A gestora 3 conta que a meditação é um exercício fundamental para a manutenção da harmonia entre os funcionários, e que além de tudo o programa de meditação fez com que sentisse a empresa como uma grande família. Diz que a sua motivação para ir trabalhar aumentou consideravelmente, e que isso se refletiu na sua vida como um todo. Para ela, é uma verdadeira fortuna trabalhar numa empresa que contempla e investe no funcionário.

As respostas obtidas nos parágrafos acima, confirmam os benefícios e efeitos da meditação, e atestam as oportunidades oferecidas com a implementação da meditação na vida corporativa da empresa. Os três entrevistados em geral, concordaram que os efeitos relativos a meditação foram benéficos, e que o principal objetivo do programa não só foi alcançado como superado. O ponto levantando com as respostas da segunda pergunta se relacionam diretamente com as afirmações de Benson (1975) de que continuidade da prática poderia proporcionar um sentimento de maior controle sobre a vida do praticante, que pode vir a controlar e equilibrar suas emoções, por sua vez na administração de estresse e da ansiedade depois de meses de prática. Além disso, as respostas acima ajudam a comprovar que a meditação pode repercutir em inúmeros âmbitos da vida (DUERR, 2004).

Verifica-se que, hoje em dia não faltam exemplos de empresas de diversos ramos que aderiam a meditação como forma de fomentar a qualidade de seus trabalhos, aumentar a produtividade, oferecer um ambiente de trabalho mais acolhedor e estimular a inovação e criatividade (TIMM, 2010). E conforme mencionado anteriormente pelas respostas da pesquisa, a experiência com a meditação influenciou diretamente a qualidade de vida e o comportamento do funcionário no trabalho. 
Figura 7. Infográfico II referente a Entrevista com Gestores

QUAL A IMPRESSÃO E A INFLUÊNCIA QUE A PRÁTICA TEVE NO DIA-A-DIA DE EMPRESA?

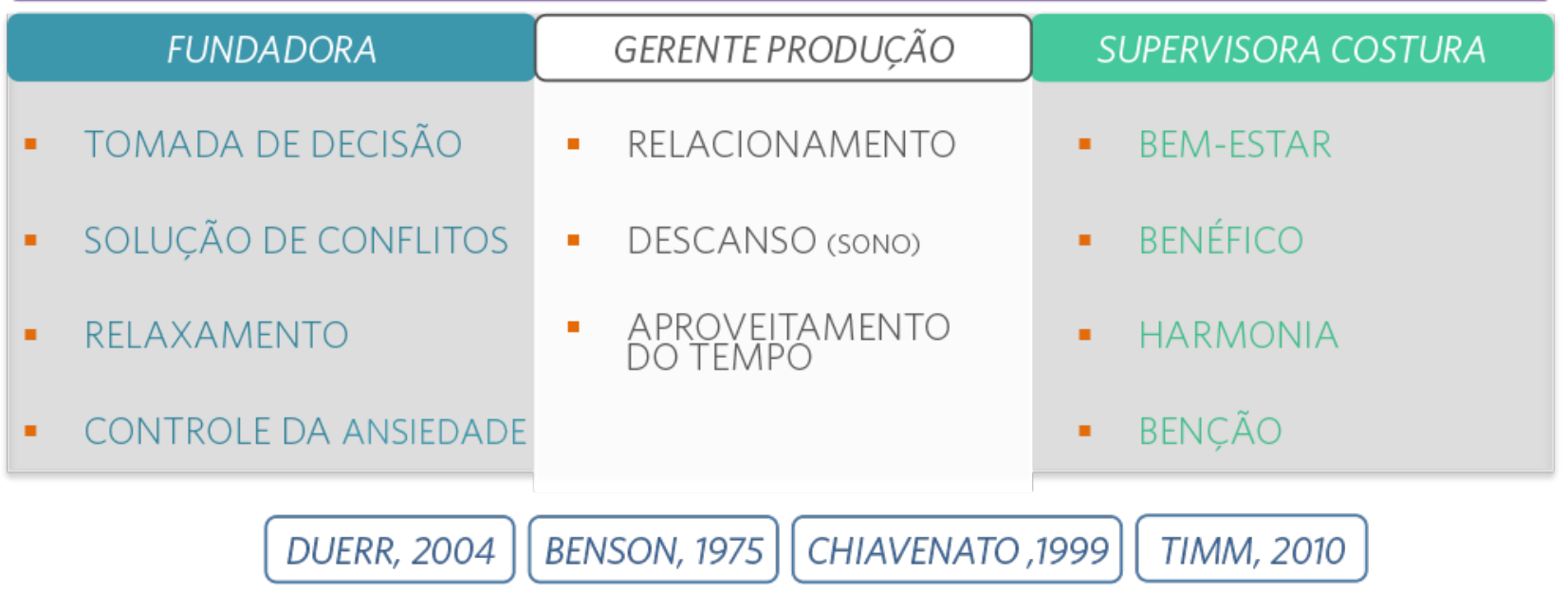

Fonte: (O Autor)

Seguindo a sequência de perguntas, a terceira e última pergunta se refere à expectativa para o futuro do programa de meditação na organização. A gestora 1 conta que espera manter o programa de meditação na empresa, de maneira a sedimentar a prática como um ritual diário na empresa. Ela espera que a organização possa sustentar esse programa à longo prazo com o intuito de oferecer as melhores condições possíveis para seus colaboradores, e aposta no sucesso do programa não somente em sua empresa como em muitas outras. Diz que os benefícios da meditação são muito maiores do que se pode pensar, contudo para realmente obter tais benefícios é necessário manter o programa a longo prazo. Portanto, concorda em continuar a estimular a prática meditativa em sua empresa como uma ferramenta organizacional capaz de transformar positivamente a vida corporativa. Atesta também que a meditação pode ser no futuro um diferencial da empresa. A gestora 2 por sua vez acredita que acha difícil o programa não continuar a ser desempenhado na organização, tamanho o envolvimento dos funcionários praticantes. Mas que mesmo assim acredita que os 'efeitos colaterais' da prática conquistaram os praticantes de tal forma que de uma maneira ou outra eles continuarão a praticar, sendo através de um programa ou não. Ela relata que espera que a meditação conquiste todos os funcionários da empresa, e que futuramente as pessoas possam meditar no local de trabalho todos os dias por pelo menos um período de 20 minutos. 
Ao iniciar sua resposta sobre o futuro do programa de meditação, a gestora 3 afirma categoricamente que vai recomendar aos seus superiores que o programa continue, tamanho os efeitos positivos experimentados com a prática de meditação durante as 8 semanas. Para ela, caso a meditação continue por um longo período nem o céu será um limite, e a organização poderá colher bons frutos oriundos do programa.

Em todas as respostas obtidas através da última pergunta destinada aos gestores da empresa, observou-se que a adoção da prática de meditação não só como um programa de qualidade de vida mas de promoção à saúde proporcionam ao indivíduo maior motivação, melhor relacionamento, maior estabilidade emocional, melhor autoimagem, maior resistência ao 'stress' e maior motivação. Sendo assim evidenciam-se diversos benefícios na organização como: uma força de trabalho mais saudável, maior produtividade e por fim um ambiente de trabalho melhor. Tais observações atestam claramente as afirmações dos autores Silva \& De Marchi (1997).

Averigua-se também, que o efeito que uma filosofia corporativa e a cultura organizacional de uma empresa exerce sobre o comportamento dos colaboradores é tão evidente que as organizações cada vez mais reconhecem e assumem a importância da cultura organizacional como fator de diferenciação dos concorrentes. Desta maneira, a gestão dos recursos humanos nas organizações passa a exercer uma função estratégica, no sentido de fazer do fator humano um diferencial de competitividade e qualidade, atestando os esforços da qualidade de vida no trabalho. De maneira análoga a Chiavenato (1999), o desafio da empresa agora é continuar a promover condições que atendam as necessidades dos indivíduos. 
Figura 8. Infográfico III referente a Entrevista com Gestores

QUAL A SUA EXPECTATIVA PARA O FUTURO DO PROGRAMA DE MEDITAČ̃̃O NA EMPRESA?

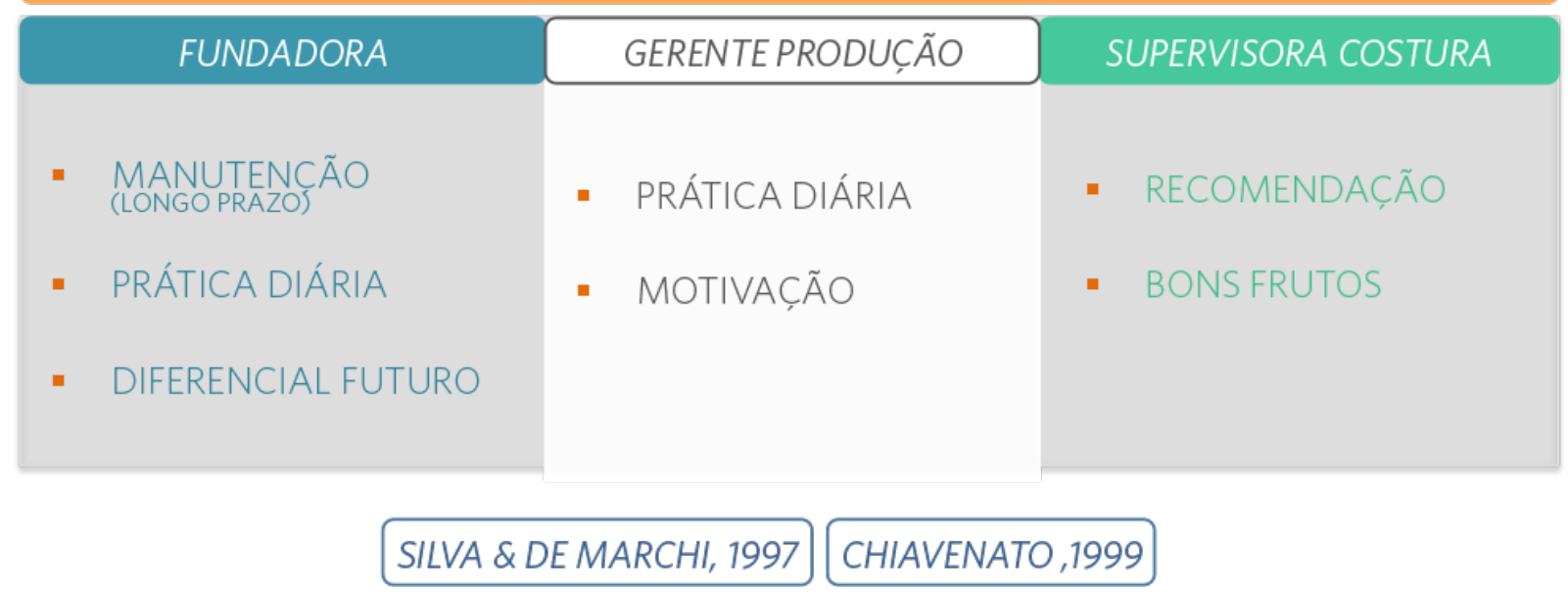

Fonte: (O Autor)

Por último, para encerrar a análise do conteúdo total proveniente das três entrevistas com os gestores, em suma parece haver fortes evidências de que a implementação do programa de meditação traz resultados satisfatórios e contribui para uma melhora no ambiente de trabalho, bem como no relacionamento interpessoal dos funcionários. É possível também identificar, no caso específico da empresa Elenice C. Leitão, que em diversos momentos que a prática de meditação se consolidou como um momento de união entre os funcionários praticantes, contribuindo assim para o espírito de unidade da organização. Ademais, a partir do testemunho das entrevistadas, notou-se melhoras na resolução de conflitos e também na tomada de decisão, corroborando para o fato de que o programa foi um sucesso no que tange os benefícios gerados e percebidos por todos os envolvidos.

\subsubsection{Resultado do Encontro com o Especialista}

Assim como foi realizada as entrevistas com os três funcionários-chave da empresa Elenice C. Leitão, de maneira análoga se sucedeu uma entrevista com o monge e médico (Amchi) budista tibetano Segyu Choepel Rinpoche, não só especialista na área de meditação e filosofia budista como na área da medicina tradicional tibetana, a fim de conceder sua opinião acerca do tema abordado. A entrevista (Anexo D) foi dividida em três partes distintas, sendo a primeira uma introdução ao perfil do entrevistado, a segunda uma introdução do tema para o entrevistado, a terceira se refere a uma avaliação do resultado da entrevista. 
Nos parágrafos a seguir, os principais pontos abordados na entrevista serão mencionados, apresentando primeiramente as respostas que mais se destacaram, e por fim a análise do conteúdo. A entrevista na íntegra encontra-se transcrita e anexada no fim do presente trabalho (Anexo D), contendo os detalhes técnicos da entrevista bem como o perfil do entrevistado.

Segyu C. Rinpoche afirma categoricamente que, meditar é o ato de se concentrar num objeto que empodera a mente, capaz de desenvolver habilidades latentes inerentes a todo ser humano. Com a prática de meditar, afirma Rinpoche, o indivíduo pouco a pouco, vai conseguindo controlar melhor suas emoções, cultivar compaixão e desenvolver maior sabedoria. À seu ver isso pode e deve afetar diretamente na qualidade das ações da pessoa. Portanto introduzir este conceito de meditação nas organizações e induzir as pessoas a entender que a maioria das confusões existentes provém dos próprios conflitos interiores, de determinados padrões de comportamentos, pode muito bem auxiliar no desenvolvimento pessoal e profissional, bem como num ponto de vista organizacional auxiliar no alcance dos objetivos das empresas.

Tais afirmativas do especialista em questão, encontram suporte e fundamento no que tange as pesquisas científicas de Benson (1975), Congleton, Hölzel \& Lazar (2015), Goleman \& Schwartz (1976), e estão em concordância com as teses de diversos autores abordados no presente estudo, como Gonzáles (2009), Khalsa (2001), Gyatso, (1999), Chiavenato (1999) e Silva \& De Marchi (1997).

Uma vez, sendo as empresas compostas basicamente por seres humanos, Rinpoche qualifica as pessoas como a alma de qualquer negócio, organização e empresa, afirmando que quanto mais as pessoas forem integradas no espírito da empresa, maior a chance das empresas serem bem-sucedidas, pois os indivíduos fazem parte do núcleo básico das organizações. Portanto, é por esta razão que se torna é importante a empresa investir na pessoa.

Desta maneira, no contexto de qualidade de vida no trabalho, cujo objetivo principal, segundo Fernandes (1996), volta-se para a conciliação dos interesses dos indivíduos e das organizações em face da melhora da satisfação do trabalhador e da melhora no desempenho produtivo da organização, a inserção de um programa de meditação pode até ser entendido como fundamental do ponto de vista estratégico.

De acordo com Segyu C. Rinpoche, a premissa fundamental budista é que a paz de espírito é proveniente de estados interiores, que as experiências como um todo são determinadas pela qualidade da mente do indivíduo, e como a 
meditação se trata de uma ferramenta que atua neste campo de interiorização e de treinamento mental, a empresa que por ventura implementar tal prática como uma ferramenta organizacional, estaria integrando o desenvolvimento dos funcionários com o próprio desenvolvimento. Os autores Bishara \& Schipani (2010) neste sentido argumentam que um caminho para alcançar tais objetivos, poderia ser desenvolvido através da concepção de programas de meditação dentro das companhias e organizações.

De maneira congruente, os autores Albuquerque \& França (1998) afirmam em outras palavras, que os esforços das organizações possuem iminentemente a obrigação de conduzir à realização humana, isto é, a qualidade só disporá de sentido se gerar qualidade de vida em meio a procura de aperfeiçoamentos da performance organizacional como um todo.

Além do mais, em correspondência com as afirmações supracitadas, Sumariva \& Ouriques (2010) concluem que tudo que possa prover maior equilíbrio físico, psíquico, social, além de oferecer uma vida mais satisfatória, e proporcionar um maior bem estar, caracteriza o alcance à qualidade de vida como uma legítima vontade humana presente em todos.

Segundo o monge budista tibetano, a prática de meditação não possui qualquer barreira ou impeditivo, podendo ela ser praticada por qualquer pessoa, de qualquer nível social e intelectual, de qualquer religião e de qualquer cultura.

Para Segyu C. Rinpoche, o mais importante a cerca da meditação, é deixar bem claro para as pessoas, que todas elas possuem um potencial enorme, e para desenvolver este potencial é preciso começar a se interiorizar através da técnica de meditação. Tendo em vista que aspectos como sabedoria, serenidade, paz e tranquilidade são independentes de cultura ou conhecimento intelectual, a prática não concebe restrições. A pessoa pode adquirir estes estados de consciência mediante a prática regular.

De fato, tais afirmativas de Segyu C. Rinpoche encontram-se respaldadas com o que Gyatso (1999) conclui a respeito da prática da meditação regular. Segundo Gyatso (1999), a meditação auxilia na superação de problemas e obstáculos interiores, como aqueles criados pela raiva, ignorância, etc.; acarreta paz interior; habilita o praticantes a cultivar intenções virtuosas, que os levam a praticar boas ações; elimina intenções não virtuosas que os levam a cometer ações prejudiciais. Por um outro lado, Kozasa et al. (2012) corroboram que a regularidade e a continuidade da prática influenciam a intensidade dos efeitos e que, portanto, a meditação pode produzir tais transformações. 
Porém, como toda regra possui exceções, existe uma contraindicação para pessoas que possuem algum tipo de debilidade ou patologia mental. Para estes casos, Segyu Rinpoche afirma que existem técnicas específicas para pessoas com problemas e disfunções mentais, e que um acompanhamento de um profissional experiente se faz necessário. De fato, segundo Davidson \& Goleman (1976) variáveis, como traços de personalidade, vivências e experiências de cada pessoa, motivações, valores e expectativas bem como predisposições genéticas também podem influenciar o tipo e a qualidade da resposta que a prática meditativa produzirá.

Rinpoche diz que "a medida que a meditação oferece essa expansão da consciência sem perda de foco e concentração, ela daria mais base para as funções administrativas, como planejar, organizar, liderar e controlar, haveria maior criatividade e inovação. A meditação é o processo que ajuda nestas questões, a ferramenta para que você possa conseguir esta expansão. Hoje a neurociência começa a explicar e embasar o que eu estou falando". E isso corrobora exatamente com o resultado das pesquisas de Benson (1975) e de Gudith, Klocke \& Mark (2008). Benson (1975) relata que a meditação fornece a base dessa transformação, argumentando que, "ela é a ferramenta para que você possa expandir sua consciência, ela fornece base para todas as funções". Já Gudith, Klocke \& Mark (2008), apontam para um outro lado, demonstrando que a quantidade de distrações e interrupções (por uso de redes sociais, telecomunicações, etc.) nos dias de hoje, provocam enorme perda de produtividade nas organizações. Segundo afirma Timm (2010), as interrupções e distrações no ambiente de trabalho configuram-se como uma das principais razões apontadas nos estudos que justificam a implementação da meditação nas empresas como propósito de manter e aumentar o nível de concentração, e consequentemente a produtividade dos colaboradores.

A respeito da sua experiência com meditação em empresas, destaca-se o caso em que foi meditar na sede da Google no Vale do Silício. Diz ele que a idéia do programa Search Inside Yourself (Tan, 2012) é muito boa, mas que existem certas limitações quanto ao programa. No contexto empresarial e corporativo, Rinpoche relata que o que ocorre é que as empresas, incluindo a Google, não se preocupam tanto com o desenvolvimento pessoal dos colaboradores mas sim com a maneira que os efeitos da meditação podem alavancar a produtividade da empresa. Em parte tal afirmativa encontra consonância com o que o autor Fry (2013) conclui, que a medida que as organizações implementam práticas no local de trabalho, como a meditação, 
estas traduzem-se em benefícios individuais e organizacionais, uma vez que, os colaboradores conseguindo atribuir significado ao seu trabalho, sentem-se atraídos por este e experimentam maior satisfação, fator que normalmente está associado ao desempenho e performance da organização. Bem como o que discorre os autores Silva \& De Marchi (1997) a respeito da capacidade das organizações responderem à demanda de seus colaboradores em relação a qualidade de vida e a necessidade de uma força de trabalho motivada, saudável e preparada para a alta competitividade e extrema concorrência presente nos dias de hoje.

Além dessa breve experiência, Segyu C. Rinpoche destacou o seu trabalho com gestores de 'startups' como a Airbnb e com uma empresa de recursos humanos (headhunter). Rinpoche relata que os resultados destas experiências foram bastante benéficos. No caso específico da empresa de recursos humanos, confere como um dos principais efeitos percebidos uma maior clareza na hora de selecionar, recrutar e contratar as pessoas, pois a empresa e seu corpo de colaboradores conseguiu perceber com maior clareza a capacidade criativa tanto dos membros da empresa como dos candidatos. De maneira geral, Rinpoche afirma que "o processo de seleção melhorou bastante, por exemplo, aumentando bastante o nível de adequação dos candidatos escolhidos para as empresas contratantes". Em relação aos benefícios da meditação, do ato de se interiorizar e se empoderar, Rinpoche reitera a criatividade funcional e a capacidade de articulação. Em sua opinião, a importância da meditação nos dias de hoje está atrelada justamente a questão da criatividade, pois cada vez mais as pessoas tem esta capacidade suprimida, muito por conta dos condicionamentos e do exagero de estímulos.

Tal experiência relatada pelo especialista em meditação Segyu C. Rinpoche, verifica-se coerente com as afirmações de Duerr (2004) e Menezes (2009), a respeito aos efeitos positivos e benefícios da prática de meditação regular, como por exemplo: melhora na tomada de decisões, aumento da criatividade, melhora da atenção/foco/concentração, diminuição do estresse e diminuição da ansiedade, entre outros.

Assim denota-se que as opiniões do especialista no assunto e os dados obtidos relacionam-se diretamente com o conteúdo teórico deste trabalho, corroborando para a idéia de que a meditação pode sim ter seus benefícios no âmbito organizacional. 


\section{Conclusão}

Nesse trabalho buscou-se encontrar indícios e respostas para melhoria da qualidade de vida no trabalho através da inserção da meditação no âmbito organizacional, de tal maneira que possibilite o ser humano dispor de seu potencial criador e transformador para sua plena realização.

Mas afinal, por que meditar no trabalho?

Em princípio, saúde e felicidade são direitos de todo indivíduo. Eis então a importância de se estimular a promoção de diferentes ferramentas como a meditação, que possui como alicerce o desenvolvimento de valores éticos e estados positivos de consciência, como satisfação, paz, altruísmo, felicidade e compaixão, considerados elementos universais na transformação positiva da consciência em um nível individual, e da sociedade em um nível coletivo.

À guisa de conclusão, a meditação por si só se traduz como o ato de se concentrar em um objeto que vai empoderando a mente, familiarizando pouco a pouco o praticante com determinados aspectos e estados positivos de consciência, de uma maneira lúcida e consciente. Em última análise, é um treinamento mental que tem por objetivo final gerar consciência dos aspectos inconscientes e conscientes da mente, e assim proporcionar o crescimento individual e despertar plenamente o potencial humano.

A prática regular da meditação em si, é capaz de produzir um série de efeitos fisiológicos e psicológicos que, segundo apontam inúmeros estudos científicos, podem ajudar na prevenção e redução de diversas condições, como na gestão de conflitos, tomada de decisões, e principalmente em situações decorrentes dos efeitos nocivos de emoções aflitivas, bem como dos efeitos do estresse, da ansiedade e da deficiência de atenção. Estes efeitos por si só conferem a meditação um lugar de destaque no que tange a qualidade de vida e por conseguinte a qualidade de vida no trabalho.

Entretanto, segundo observam os grandes mestres de meditação, os efeitos provenientes do estado meditativo não compreendem a meta da meditação. Neste ponto de vista, a finalidade da meditação consiste em adquirir meios hábeis para superar as adversidades no tocante as ações de corpo, palavra e mente; utilizar os fatores e ganhos associados à prática (serenidade, 
discernimento, sabedoria, força, etc.) não somente para si próprio como para benefício de todos os seres, e tornar-se uma meio poderoso de força e bem estar para os outros e para o mundo.

Não obstante, com base em tudo que foi levantado e elucidado neste estudo, bem como na amostra estudada, os resultados permitem concluir que, torna-se evidente a importância e relevância da meditação no âmbito da vida organizacional, seja para a melhoria da qualidade de vida pessoal e profissional dos trabalhadores, seja para a melhora do convívio social, seja para a maior satisfação do trabalhador com a organização, e consequentemente para a melhora dos resultados e da produtividade das empresas.

O que pode ser observado é que além de ter sido possível alcançar os objetivos deste estudo, os resultados auferidos reforçam as informações obtidas nas entrevistas, fornecendo um novo prisma de entendimento, fechando o conceito de meditação nas empresas e enriquecendo o debate acerca do tema proposto.

Dentre as principais questões abordadas salientam-se a percepção da meditação no dia-a-dia da empresa, bem como os efeitos e benefícios da aplicação da meditação no ambiente de trabalho. A utilização dessa ferramenta se mostra bastante eficaz no âmbito organizacional, e talvez seja este o ponto principal do presente estudo, pois abordar a implementação da meditação nas organizações é algo bastante discutido e visto hoje como uma preciosa oportunidade para o desenvolvimento sustentável das empresas.

Verificaram-se claramente, tanto através da pesquisa bibliográfica, como do conteúdo teórico e através do estudo de caso, os efeitos e benefícios da meditação bem como a implementação de um programa de meditação no trabalho, contribuindo tanto para a melhora do ambiente laboral quanto para a qualidade de vida do colaborador.

Meditar no âmbito do trabalho, favorece tanto os empregados quanto os empregadores, a medida que oferece uma rica gama de benefícios, tanto pessoais quanto profissionais, caracterizando-se como uma oportuna ferramenta de trabalho. Além do mais, pode ser observada do ponto de vista estratégico como um diferencial competitivo, uma vez que em face da melhora da satisfação do trabalhador e da melhora no desempenho produtivo da organização concilia concomitantemente os interesses dos indivíduos (bem estar) e das organizações (eficácia organizacional).

Assim, o presente estudo sugere que a meditação pode sim ser utilizada a nível individual e coletivo no âmbito organizacional, tendo em vista não apenas 
os diversos efeitos positivos atrelados a essa prática milenar, mas pelo esforço contínuo de melhoria dos processos de trabalho, da melhoria das relações interpessoais, como para aproveitar o potencial humano em plenitude.

Normalmente, as organizações que dão importância e se preocupam com a qualidade de vida no trabalho, observam o aumento do potencial dos colaboradores como fator determinante na busca de maior produtividade e melhor qualidade, uma vez que os indivíduos tendem a apresentar atitudes positivas quando as empresas oferecem ambiente seguros, de qualidade, que proporcionam bem estar e satisfação. Por se tratarem da base e da força motriz de uma organização, os colaboradores são responsáveis diretos pelo bom andamento do negócio.

Levando-se em consideração que, os indivíduos procuram através de sua ocupação e trabalho obter equilíbrio, satisfação e bem estar, e que a qualidade de vida no trabalho se caracteriza como a busca do equilíbrio entre o homem e o trabalho, observa-se a relação direta entre a prática de meditação, a qualidade de vida no trabalho e as organizações.

Desta forma, abordar a meditação nas organizações e corporações, hoje em dia, caracteriza-se como uma oportunidade valiosa para as empresas e o colaborador/funcionário/trabalhador, pois trata-se de uma necessidade de vital importância e relevância para que o maior ativo da organização, o ser humano, tenha condições para desempenhar com eficácia e satisfação suas tarefas profissionais. Desta maneira, todos saem ganhando, tanto a instituição como seus colaboradores.

Assim sendo, o presente estudo se caracteriza como mais uma contribuição para a evolução dessa área, a qual se encontra em um estágio inicial de desenvolvimento. Embora os resultados colhidos tenham sido consoantes e convergentes com outros estudos e pesquisas, ainda necessitam ser investigados em maior profusão.

Esta investigação apontou que a meditação e a inserção da meditação no trabalho se mostra bastante interessante pois durante o período de estudo, comprovou-se a sua influência positiva no dia-a-dia dos colaboradores da empresa objeto de estudo.

Porém, ressalta-se que tanto os estudos sobre meditação quanto a prática da meditação em si, ainda provocam visões destoantes e opiniões discordantes tanto quanto ao consentimento de sua utilidade no âmbito individual e organizacional, quanto a sua verdadeira eficácia em matéria de saúde. 
Assim, uma observação pertinente obtida com este trabalho, é de que a meditação não consiste em um remédio para todos os males (panacéia) sequer a salvação das empresas. Se trata de uma ferramenta muito eficaz em muitos aspectos, um elemento que complementa as funções administrativos das organizações mas que de maneira alguma se propõe a resolver todas as questões e obstáculos organizacionais.

\subsection{Sugestões e Recomendações para Novas Pesquisas}

Embora a maior parte dos objetivos deste estudo tenham sido logrados e alcançados, contribuindo para uma maior compreensão acerca dos efeitos da prática da meditação num ambiente organizacional, podemos apontar algumas recomendações.

Considerando-se a significância e proeminência da meditação e suas diversas particularidades como objeto de estudos científicos, propõe-se que este se trata de um campo ainda a ser esmiuçado pela comunidade científica brasileira em seus centros de pesquisa. A fase atual ainda em andamento na qual se deparam os estudos e pesquisas sobre meditação concebe um terreno rico para seu exame e verificação, ao passo que as evidências vão convertendo-se cada vez mais irrefutáveis e conclusivas, tais fatos viabilizam progressivamente a sua inserção e difusão no âmbito organizacional.

Como desdobramento, este estudo pode ser uma ferramenta de apreciação de empresas e organizações que por ventura desejam saber mais sobre aspectos vinculados a prática de meditação, bem como implementação de um programa de meditação no trabalho.

Aproveitando a oportunidade levantada pelos parágrafos acima, um estudo mais detalhado a respeito das diferentes técnicas de meditação e seus efeitos nas organizações poderia também ser de grande interesse para o mundo corporativo empresarial, bem como para a comunidade envolvida com meditação.

Desta feita, recomenda-se a realização de mais pesquisas e estudos, com o rigor científico necessário, que incorporem bases tanto em ordem qualitativa como quantitativa, com amostragens maiores e delimitações mais extensas, principalmente em território brasileiro, para que haja uma maior e mais abrangente validação da meditação com uma valiosa ferramenta de melhoria da qualidade de vida, em seus múltiplos aspectos. 


\section{Bibliografia}

Abramides, M. B. C., Cabral, M. S. R. Regime de acumulação flexível e saúde do trabalhador. São Paulo em Perspectiva, São Paulo, v.17, n.1, p 3-10, 2003.

Albuquerque, L. G. Competitividade e recursos humanos, Revista de Administração da USP, v. 27, n.4, São Paulo, 1992.

Albuquerque, L. G., França, A. C. L. Estratégias de recursos humanos e gestão da qualidade de vida no trabalho: o "stress" e a expansão do conceito de qualidade total. Revista de Administração, v. 33, n.2, São Paulo, 1998.

Alves, D. B. Qualidade de Vida Nas Organizações, Universidade Candido Mendes, Rio de Janeiro, 2009.

Aquino, C. P. Administração de Recursos Humanos: uma introdução. São Paulo, Atlas, 1979.

Ashmos, D. P., Duchon, D. Spirituality at work: a conceptualization and mesure, Journal of Management Inquiry, vol.9, n.2, p.134-145, 2000.

Benson, H. The Relaxation Response, New York, Morow, 1975.

Benson, H. Relaxation Response: history, physiological basis and clinical usefulness. Acta Medica Scandinava (suppl.), v. 660, p. 231, 1982.

Benson, H. Medicina Espiritual: O Poder Essencial da Cura. São Paulo, Elsevier, 1998.

Bishara, N. D., Chipani C. A. Complementary Alternative Benefits to Promote Peace, Journal of Business Ethics, v.89, p.539-557, 2010.

Brasil. Ministério da Saúde. Secretaria de Atenção a Saúde. Departamento de Atenção Básica. Política Nacional de Praticas Integrativas e Complementares no SUS - PNPIC-SUS. Portaria no. 971 de 3 de maio de 2006.

Brefczynski-Lewis, J. A., Lutz, A., Schaefer, H. S., Levinson, D. B., Davidson, R. J. Neural correlates of attentional expertise in long-term meditation practitioners. Proc. Natl. Acad, Sci. U.S.A., 104, PP. 11483-11488, 2007.

Cardoso, R., Souza, E., Camano, L. Meditation in Health: an operation definition. Brain Research Protocols, v. 14, p. 58-60, 2004.

Cardoso, R., Souza, E., Camano, L. Meditação em saúde: definição, operacionalização e técnica. In: Rossi, A. M., Quick, J. C. Perrewe, P. L. Stress e qualidade de vida no trabalho: o positivo e o negativo. São Paulo, Atlas, p. 16386, 2009.

Chiavenato, I. Gestão de Pessoas: o novo papel dos recursos humanos nas 
organizações. Rio de Janeiro, Campus, 1999.

Chiavenato, I. Introdução a teoria geral da administração. São Paulo, McGrawHill do Brasil, 1983.

Congleton, C., Hölzel, B. K., Lazar, S. W. Mindfulness Can Literally Change Your Brain. Harvard Business Review, v.93, n.1-2, p. 309-318, 2015.

Davidson, R. J. Well-being and affective style: Neural substrates and biobehavioural correlates. Phisolophical Transactions of the Royal Society B, 2004.

Davidson, R. J., Goleman, D. J. Attentional and effecive concomitants of meditation: A cross-sectional study. Journal of Abnormal Psychology, 1976.

Doing Time, Doing Vipassana. Direção de Eilona Ariel e Ayelet Menahemi, Israel: Karuna Films, 1997. 1 DVD (52 min.), son., color.

Duerr, M. A powerful silence: the role of meditation and other contemplative practices in American life and work. 2004.

Durant, W. The Story of Philosophy: The Lives and Opinions of the Greater Philosophers. New York, Simon \& Schuster, 1926.

Fernandes, E. C. Qualidade de Vida no Trabalho: como medir para melhorar. Salvador, Casa da Qualidade, 1996.

Fernandes, E. C., Gutierrez, L. H. Qualidade de Vida no Trabalho: uma experiência brasileira. Revista de Administração São Paulo, v. 23, n. 4, 1996.

Fernandez-Ballesteros, R. Calidad de Vida ¿Es un concepto psicológico? Revista Española Geriatrya e Gerontologia, v. 39(3), p.18-22, 2004

Ferreira, A. B. H. Novo Aurélio Século XXI: O Dicionário da Língua Portuguesa. Rio de Janeiro, Nova Fronteira, 1999.

Fleck, M. P. A., Louzada, S., Xavier, M., Chachamovich, E., Vieira, G., Santos, L., Pinzon, V. A aplicação da versão em português do instumento de avaliação de qualidade de vida da Organização Mundial de Saúde (WHOQOL100). Rio de Janeiro, v.34, n.2,p.198-205, 1999.

França, A. C. L. Qualidade de Vida no Trabalho: conceitos, abordagens, inovações e desafios nas empresas brasileiras. Revista Brasileira de Medicina Psicossomática. Rio de Janeiro, 1997.

Freitas, M. E. O "Day-after" das Reestruturações: As Irracionalidades e a Coisificação do Humano. Rae Light, v.6, n.1, p.5-7, São Paulo, 1999.

Fry, L. W. Toward a theory of spiritual leadership. The Leadership Quarterly, v.12, n.14, p.693-727, 2003.

Goleman, D. J. A Mente Meditativa. São Paulo, Atica, 1997.

Goleman, D. J. The Meditative Mind: The varieties of meditative experiences. New York, G. P. Putnams Sons, 1988. 
Goleman, D. J., Schwartz, G. E. Meditation as an intervention in stress reactivity. Journal of Consulting and Clinical Psychology, v.44, n.3, p.456-466, 1976

Gomes, R. A Meditação e a Neurociência. Joinville, Ed. Clube de Autores, 2016.

Grisci, C. L. I. Trabalho, tempo e subjetivdade: impactos da reestruturação produtiva e o papel da psicologia nas organizações. Psicologia: Ciência e Profissão, Brasília, 1999.

Grossman, P., Niemann. L., Schimdt, S., Walach, H. Mindfulnees-based stress reduction and health benefits: a meta-analysis. Journal of Psychosomatic Research. v. 57, p.35-43, 2004.

Gudith, D., Klocke, U., Mark, G., The Cost of Interrupted Work: More Speed and Stress. Proceedings of the SIGCHI Conference on Human Factors in Computing Systems, p. 107-110, New York, ACM, 2008.

Gyatso, G. K. O Caminho Alegre da Boa Fortuna. São Paulo, Tharpa, 1999.

Holzel, B. K., Carmody, J., Vangel, M., Congleton, C., Yerramsettu, S. M., Gard, T., Lazar, S. W. Mindfulness practice leads to increases in regional brain gray matter density, Psychiatry Res., 191, PP. 36-43, 2011.

Jain, S., Shapiro, S. L., Swanick, S., Roesch, S. C., Mills, P. J., Bell, I., Schwartz, G. E. A randomized controlled Trial of mindfulness meditation versus relaxation training: effects on distress, positive states of mind, rumination and distraction. Annals of Behavioral Medicine, v.33, n.1, p11-21, 2007

Jha, A. P., Stanley, E. A., Kiyonaga, A., Wong, L., Gelfand, L. Examining the protective effects of mindfulness training on working memory capacity and affective experience. Emotion, v.10, p. 54-64, 2010.

Juniper, F. Awakening the Mind: An Introduction to Buddhist Training. San Francisco, Juniper Books, 2016.

Juniper, F. Learning to Meditate: Concentration and Analytical Meditation. San Francisco, Juniper Books, 2016.

Khalsa, D. S. Meditation is a medicin. New York, Fireside, 2001.

Kozasa, E. H., Sato, J. R., Lacerda, S. S., Barreiros, M. A. M., Radvany, J., Russell, S. A., Sanches, L. G., Mello, L. E. A. M., Amaro Jr, E. Meditation training increases brain efficiency in attention task. Neurolmage. v.59, issue 1, p745-749, 2012.

Kristeller, J. L., \& Hallet, B. An exploratory study of a meditation-based intervention for binge eating disorder, 1999.

Lazar, S. W. et al. Functional brain mapping of the relaxation response and meditation. NeuroReport, v. 11, p. 1581, 2000.

Lazar, S. W. et al. Meditation experience is associated with increased cortical thickness. NeuroReport, v. 16, p. 1893, 2005. 
Levering, R. Um execelente lugar para se trabalhar: o que torna alguns empregadores tão bons (e outros tão ruins). Rio de Janeiro, Qualitymark, 1986.

Levine, M. The Positive Psychology of Buddhism and Yoga, Paths to a Mature Happiness. New Jersey, Lawrence Erlbaum Associates, 2000.

Marins, L. Livre-se dos “Corvos”. São Paulo, Harba, 2003.

Martin, J. R. Mindfulness: a proposed common factor. Journal of Psychotherapy Integration, v.7, n.4, p.291-312, 1997.

Matos, F. G. Empresa Feliz, São Paulo, Editora Makron Books, 1996.

Menezes, C. B. Por que Meditar? A relação entre o tempo de prática de meditação, o bem-estar psicológico e os traços de personalidade. Universidade Federal do Rio Grande do Sul, Instituto de Psicologia, Porto Alegre, 2009.

Menezes, C. B.; DellAglio, D. D. Os efeitos da meditação a luz da investigação cientifica em Psicologia: revisão de literatura. Psicologia: ciência e profissão. Brasilia, v.29, n.2, p.276-289, 2009.

Minayo, M. C. S.; Hartz, Z. M. A.; Buss, P. M. Qualidade de Vida e saúde: um debate necessário. Ciência \& Saúde Coletiva. Rio de Janeiro, Brasília, v.5, n.1, p.7-18, 2000.

Naranjo, C. Entre meditação e psicoterapia. Rio de Janeiro, Ed. Vozes, 2005.

Organização Mundial da Saúde. Constituição. Nova York, OMS, 1946.

Rinpoche, S. C., Meditação. San Francisco, Juniper Books, 2016.

Santi, A. Meditação: Pare. Respire. E mude a sua vida. São Paulo, Editora Abril, 2018.

Schwartz, G. E., Davidson, R. J., Goleman, D. J. Patterning cognitive and somatic processes in the self-regulation of anxiety: effects of meditation versus exercise. Psychosomatic Medicine, v.40, n.4, p.321-329, 1978.

Shapiro, D. L., Schwartz, G. E., Santerre, C. Meditation and Positive psychology. In: Snyder, C. R, Lopes, S.J. Handbook of positive psychology. New York: Oxford USA Trade, p.632-645, 2005.

Shapiro, D., Walsh, R. N. Meditation, classic and contemporary perspective. Hawthorne, Aline Publishing Company, 1984.

Silva, M. A., De Marchi, R. Saúde e qualidade de vida no trabalho. São Paulo, Best Seller, 1997.

Solarz, P. Meditation and cognitive, affective and behavioral change inside and out of the classroom. Evergreen State College, Olympia, Washington, 2009.

Sumariva, A., Ouriques, M. A. Qualidade de vida ocupacional dos profissionais de educação física que atuam em Blumenau, SC nas modalidades de musculação e ginástica. Blumenau, 2010. 
Tan, C.. Search Inside Yourself: The Unexpected Path to Achieving Sucess Happiness (and World Peace). Harper One, USA, 2012.

Timm, J. Why meditation has a place in business? Toronto, Canadian Business, vol.83, n.6, p.74, 2010.

Vasconcelos, A. F. A qualidade de vida no trabalho: origem, evolução e perspectivas. São Paulo: Caderno de Pesquisas de Administração. v.8, n.1, 2001.

Vines, J. Pesquisadora Americana fala sobre os efeitos da meditação. Folha de São Paulo. São Paulo, 2013. Disponível em: http://www1.folha.uol.com.br/equilib riosaude/1244551-pesquisadora-americana-fala-sobre-os-efeitos-da-meditacao.s html (Acesso em: 09 de abril de 2016).

The WHOQOL Group. The World Health Organization quality of life assessment (WHOQOL): position paperfrom the World Health Organization. Social Science and Medicine, v.10, p.1403-1409, 1995. 


\section{Anexos}

\subsection{Anexo A}

\section{Questionário dos Participantes.}

Questionário ${ }^{\circ} 1$

Nome:

Sexo: 1 - Masculino ( ) 2 - Feminino ( )

Idade:

anos

Ocupação:

Situação conjugal:

1- Casado ou morando junto ( ) 2-Divorciado(a)（）3-Viúvo(a)（） 4-Solteiro(a)（）

Escolaridade: 1-Ensino fundamental ( ) 2-Ensino Médio ( ) 3-Ensino Superior ( )

Já havia meditado?

Se sim:

Há quanto tempo?

Com que frequência?

Com que duração?

Qual foi sua primeira impressão da prática de meditação no trabalho? 
Questionário $n^{\circ} 2$

Nome:

Em geral, como você acha que a meditação reflete na sua vida?

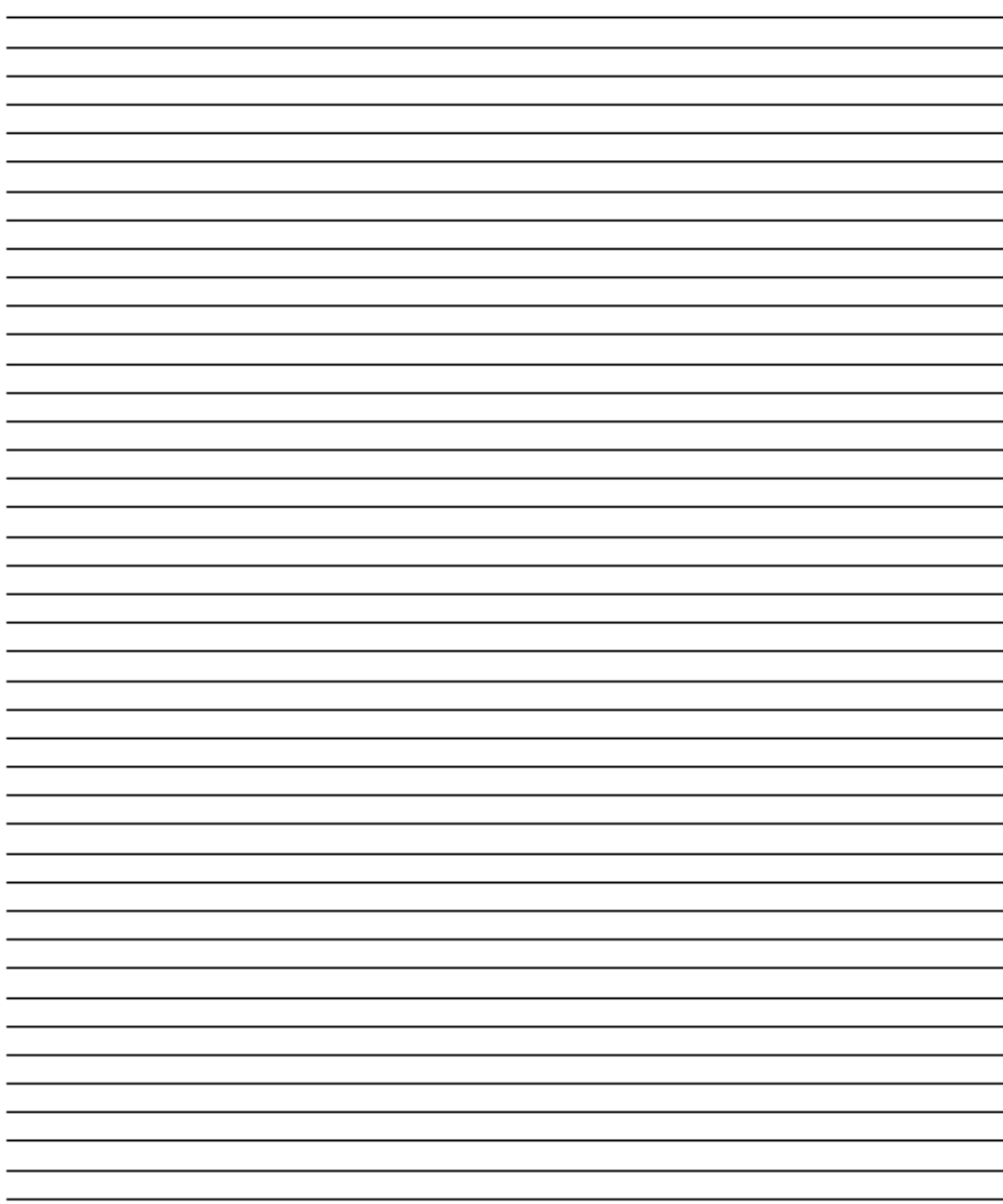


7.2.Anexo B

Questionários dos Gestores.

Questionário "Gestores"

Nome:

1- Em geral, qual é a sua opinião a respeito do ambiente de trabalho da empresa antes, durante e depois do programa de meditação? 
2- Qual é a sua impressão sobre a influência que a prática de meditação teve no dia a dia da empresa?

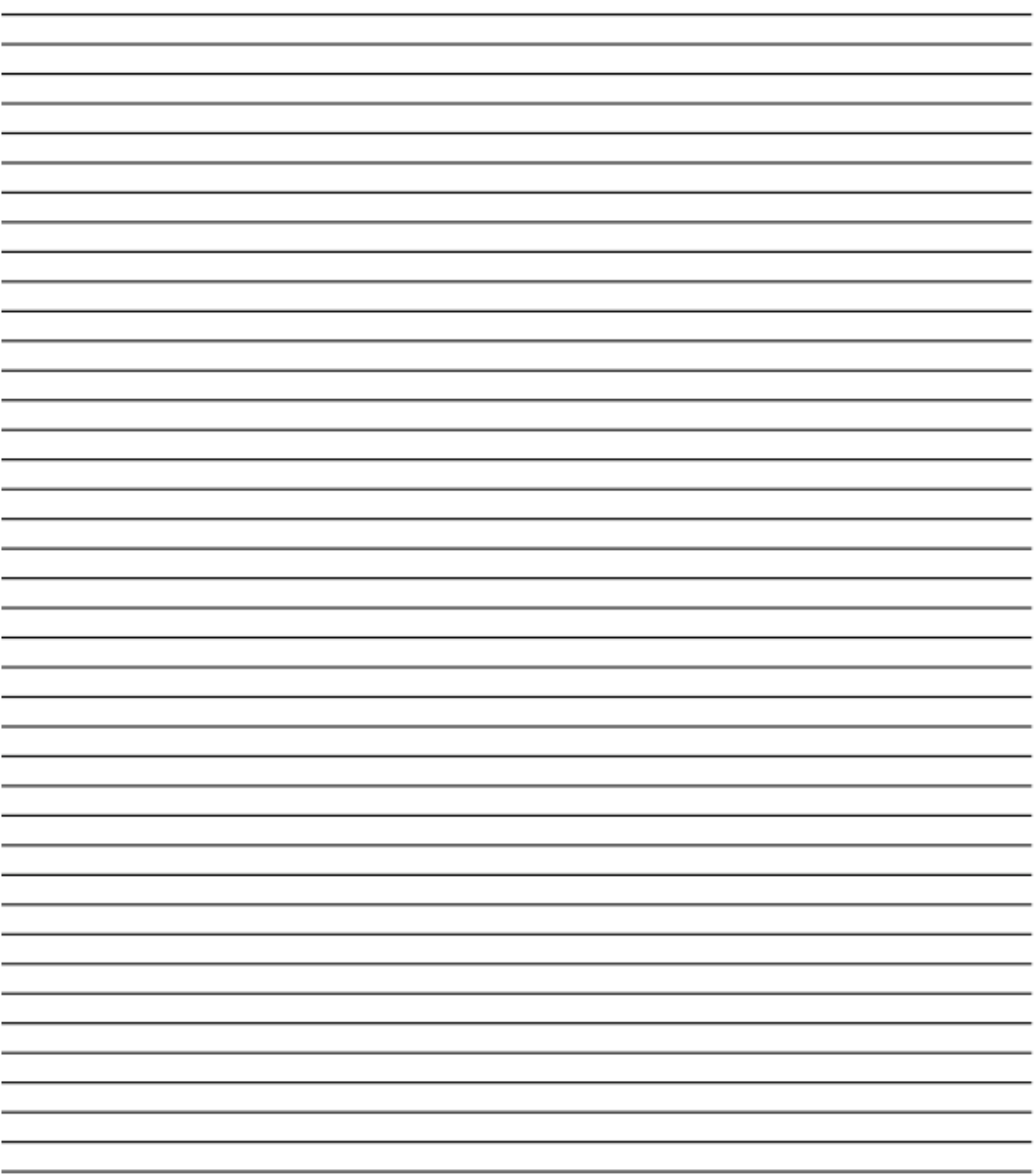


3- Qual é a sua expectativa para o futuro em relação ao programa de meditação na empresa?

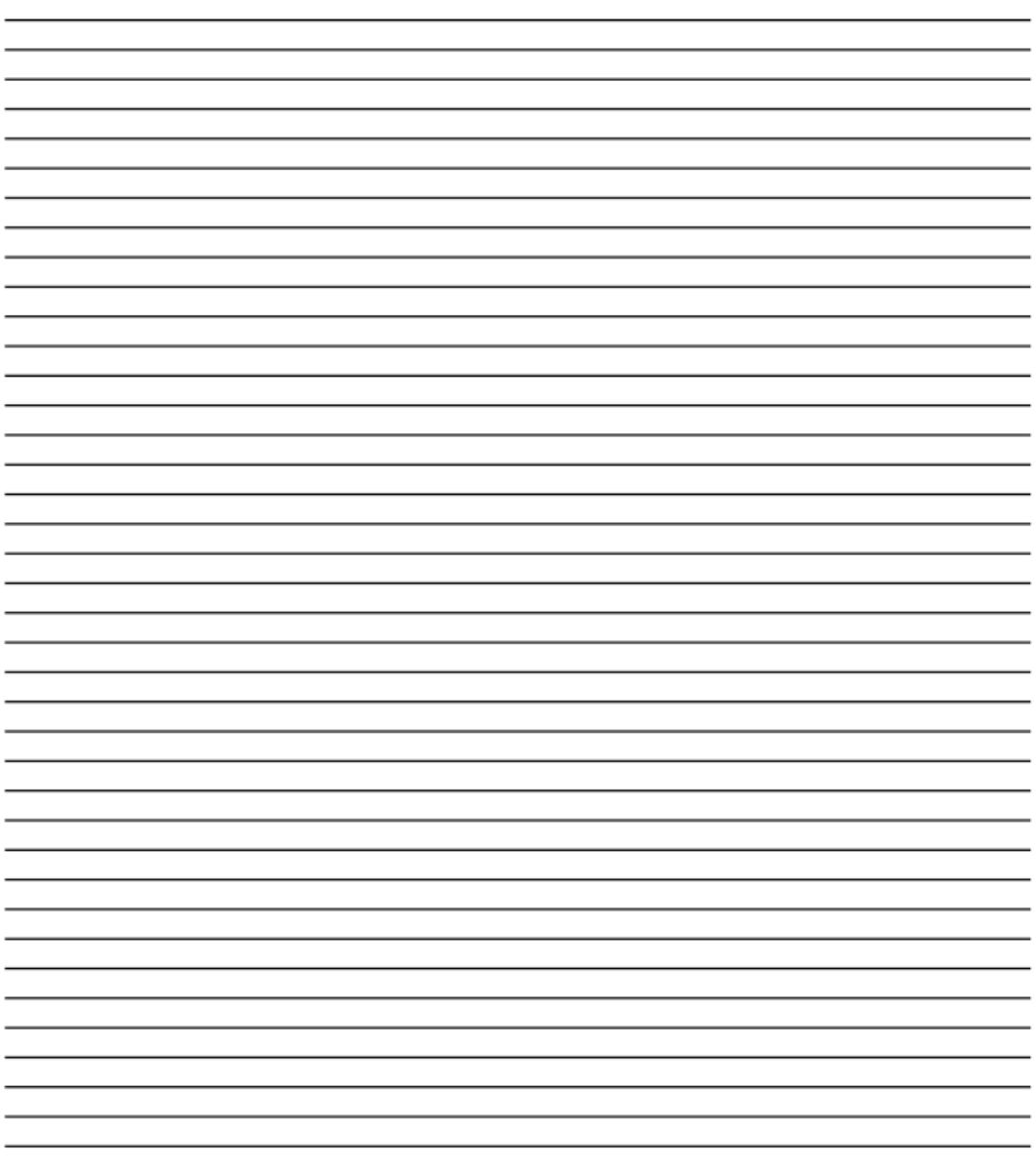




\subsection{Anexo C}

Apostila do Método Arte de Meditar: Na Onda da Vida.
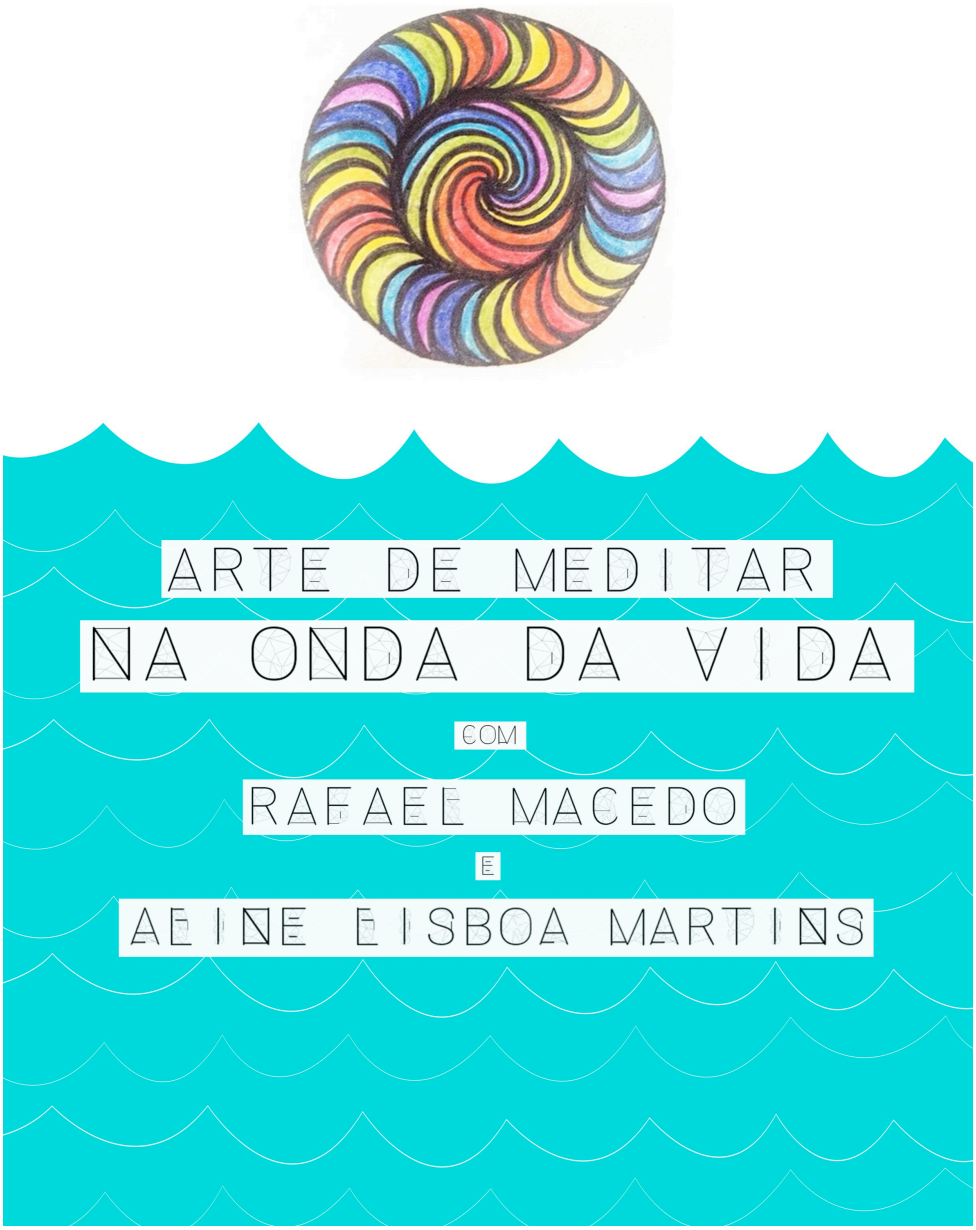


\section{MEDITAÇÃO}

Meditar é fácil, não tem mistério algum, pelo contrário. Trata-se de uma prática simples que pode ser realizada a qualquer momento, em qualquer lugar. No entanto, para ancorar a meditação somente duas coisas são indispensáveis: disciplina e dedicacão. Aqui eu vos convido para esta jornada de voltar-se para dentro de si, compreender a fluidez da vida e assim expandir vosso verdadeiro potencial. Ir além dos limites interiores, para imbuir vossos esforços com serenidade, liberdade e alegria. Melhorar a experiência do dia-a-dia ao pacificar os pensamentos e comportamentos que causam agitação através da pratica da meditaçăo e autoconsciência.

\section{MANTRA}

Mantra significa proteção a mente. É um dos métodos oferecidos como forma de relaxar, equilibrar a atmosfera revitalizando a energia da tríade CORPOMENTE-ENERGIA, consiste na recitaçăo de mantras. Neste caso entoaremos o sagrado Mantra OM AH HUM, como uma maneira de proteger a mente;

\section{DICAS VALIOSAS:}

1) Procure praticar de preferência em um lugar limpo, silencioso e confortável;

2) Se você se sentir entediado ou inquieto com a mente cheia de pensamentos, não se preocupe. Isso significa que emoçð̃es profundas estão sendo dissolvidas e liberadas. Relaxe. Continuar a meditaçăo ajuda a eliminar essas influencias da mente;

3) Se sentir sonolência durante a meditação, não tem problema. Mas é sinal de que você precisa de mais tempo de descanso;

4) Se durante a prática de meditação você perceber algum sentimento ou expectativa, simplesmente volte a atençăo para respiraçăo.

5) Se você se desconcentrar de vez em quando, prestando atençăo no barulho, nos ruídos externos ou então perceber-se pensando em outras coisas, volte sua atençăo para respiração,

6) No começo o surgimento de dores em partes do corpo é possível e natural, não se preocupe; 
7) Pode-se sentar no chão de pernas cruzadas, apoiando-se num tapete aconchegante, ou se preferir, sentar normalmente numa cadeira;

8) Concentrar-se na respiração nåo é tentar controlar ou alterá-la. Trata-se de apenas observar os movimentos, as variaçø̃es da temperatura, da profundidade, do ritmo, da velocidade;

9) Lembre-se que o que realmente vale é desfrutar a experiência;

10) Sugiro a prática da técnica logo ao acordar e/ou antes de dormir.

\section{APRESENTACÃO DO MÉTODO:}

1- Sente-se e mantenha uma postura confortável. Procure manter a coluna o mais ereta possível durante toda a prática;

2- Junte as mãos na altura da testa, entoe o mantra OM (abertura do corpo) e visualize a cor branca:

3- Desça as mãos para garganta, vibre AH (abertura do poder) visualizando a cor vermelha:

4- Leve as mãos ao centro do peito, reverbere HUM (abertura do coraçăo) visualizando a cor azul:

5- Estabeleça a Intenção:

"AQUI E AGORA, EU DECLARO QUE ESTOU DISPOSTO A SER QUEM EU VERDADEIRAMENTE SOU. EU RECONHECO MINHAS QUALIDADES E TALENTOS, EU MERECO E ME PERMITO. EU ABRO MEUS CANAIS E ORDENO QUE A ENERGIA FLUA POR TODO MEU CORPO, MEU SER, MINHA VIDA E MEU MUNDO. QUE A VERDADE ILUMINE A IGNORANCIA E A PERFEITA AÇÃO SE FAÇA. QUE ASSIM SEJA, ASSIMÉ."

6- Vinte e um (21) minutos observando e "focando" na respiraçåo;

7 - Encerre a sess åo: junte as palmas das mãos na altura do peito e agradeça;

8- Finalize sua prática:

"AQUI E AGORA EU ORDENO QUE IMPERE O ESTADO DE PAZ E REINE O AMOR. QUE MEU CORACAO SEJA INUNDADO PELA COMPAIXAO E MINHA VIDA SEJA UM ETERNO DESFRUTAR. DEDICO E OFERECO OS MERITOS GERADOS POR ESTA PRATICA PARA O BEM-ESTAR DE TODOS OS SERES VIVOS." 


\section{EXERCÍCIO COMPLEMENTAR: RESPIRAÇÄO COMPLETA}

Esta técnica acalma, relaxa e oxigena todo o corpo;

\section{COMO FAZER:}

1a fase - Respiraçáe abdominal - Aproveite o impulso que vem de dentro, liberte o abdômen que vai para frente, deixe entrar livremente $o$ ar, o qual acentua o movimento abdominal. Com isto ficará cheia toda a base pulmonar.

$2 a$ fase - Respiraçăo mediana - Tendo o ar preenchido a base do pulmáo, devera encherse agora a parte media, $e$ isso será facilitado com o alargamento das costelas de parte mediana do tórax, num aumento lateral do volume torácico. É possível que o principiante sinta dificuldades, em virtude do estado de atrofia em que tem seus músculos respiratórios, depois de tantos anos de respiraçăo mesquinha. Exercite-se colocando as măos nas costelas e procure sentir que elas se alargam.

3a fase - Respiraçáe subclavicular - Depois de bem alimentadas de ar a base e a parte media, resta fazer o mesmo com o ápice do pulmáo o que se consegue erguendo suavemente os ombros. Concomitantemente, o abdômen, que permanecia avançado, volta à sua posiçăo normal.

A expiraçáo faz-se de maneira inversa, como que esprememos a esponja pulmonar, a partir de cima até embaixo. Para isto, solte inicialmente a pressăo reinante no ápice, depois na parte media $e$, finalmente, pela contraçắo e sucçăo abdominal, expila todo o ar, igual zinho como faz na "limpeza dos pulmóes".

Na primeira semana, comece com seis respiraçōes em duas sessōes diárias (ao amanhecer $e$ ao anoitecer). Nas semanas subseqũentes, em cada sessăo acrescente uma respiraçăo, até completar doze.

OBS: Tanto a inspiraçăo como a expiraçăo se processam cada uma como um movimento único e uniforme apesar de ser triplo, como vimos. Quando perfeita, a inspiraçăo é uma lenta, uniforme, ininterrupta e harmoniosa ondulaçăo que, a partir do ventre, movimenta todo o tronco. $\mathrm{O}$ mesmo se pode dizer da expiraçăo.

\section{BENEFICIOS:}

Altamente eficaz no combate ao stress e ansiedade; Estimula a açăo do diafragma, músculo importante da respiraçăo, massageando as vísceras abdominais, promovendo uma absorçăo maior de oxigênio do que na respiraçắo superficial; Massageia o coraçăo; Evita a prisăo de ventre; Equilibra o sistema endócrino; Desenvolve e tonifica todo o aparelho respiratório; Melhora o funcionamento do estomago, vesícula, pâncreas, baço, rins e fígado; Melhora a qualidade do sangue pela maior eliminaçăo do gás carbônico e absorçăo do oxigênio; Aumenta a energia psíquica; Desenvolve auto confiança, auto domínio entusiasmo; Tranquiliza a mente, purifica as nadis (canais energéticos) e ativa os chackras; 


\section{TEXTO ILUSTRATIVO}

Agora convido cada um a se recordar de um momento feliz na vida, um momento de paz e felicidade.

Com essa energia, traga uma intenção para seu dia.

Que a gente possa carregar essa plenitude durante toda a pratica de meditação.

Observamos o ato de inalar e exalar com nosso nariz, e com a respiração ajudamos a relaxar as partes do corpo que estão tensas.

Concentrando-se na ponta do nariz, observamos a entrada de ar pelas narinas, a passagem do ar pela garganta até preencher os pulmø̃es. O movimento recomeça, mas na verdade ele nunca termina. Neste ciclo respiratório, o fim sempre é um novo começo.

Repare, observe a sensação do ar penetrando e saindo de suas narinas, ou se você preferir, repouse sua atenção nos movimentos do seu ventre a medida que você respira. São opostos que se complementam, ambos se tornam um movimento único e natural, como o fluir de um rio em direção ao mar, como o fluir de uma onda e da Vida.

Procure respirar naturalmente, como se todo o tempo do mundo estivesse sendo conduzido pela sua respiração.

Muitas vezes a mente pode escapar, algum pensamento ou emoçăo pode nos fazer distrair, mas a gente volta o foco para a respiraçăo, observando a ponta do nosso nariz ou o abdomen. Lembre-se que assim como as tempestades e as nuvens, os pensamentos também surgem e desaparecem.

Observando a maneira como estes movimentos acontecem nos conectamos com o momento presente. 


\section{A PRÁTICA PASSO A PASSO}

1) Sentando no chão de pernas cruzadas ou em uma cadeira ache uma postura de conforto;

2) Relaxe os braços em cima das pernas, retirando qualquer peso nos ombros.

Relaxe a musculatura, relaxe sua face. Deixe que sua mente e seu corpo relaxem;

3) Feche os olhos serenamente;

4) Respire fundo 3 vezes;

5) Junte as palmas das måos na altura da testa (terceiro olho) e entoe o mantra OM. Imagine uma luz branca. (abertura do corpo);

6) Lembre-se de respirar calmamente. Encontre seu ritmo;

7) Agora com as mãos na altura da garganta (quinto chakra) entoe o mantra $\mathrm{AH}$. Imaginar neste ponto uma luz vibrante de cor vermelha. (abertura da palavra);

8) Desça as måos na altura do coração (quarto chakra) e vibre o mantra HUM. Imaginar a cor azul no coração. (abertura do mente);

Agora você esta centrado, aberto e pronto para iniciar a prática.

9) Afirme internamente:

"AQUIE AGORA, EU DECLARO QUE ESTOU DISPOSTO A SER QUEM EU VERDADEIRAMENTE SOU. EU RECONHEÇO MINHAS QUALIDADES E TALENTOS, EU MEREÇO E ME PERMITO. EU ABRO MEUS CANAIS E ORDENO QUE A ENERGIA FLUA POR TODO MEU CORPO, MEU SER, MINHA VIDA E MEU MUNDO. QUE A VERDADE ILUMINE A IGNORANCIA E A PERFEITA AÇÃO SE FAÇA. QUE ASSIM SEJA, ASSIM É."

10) Procure tranquilamente com a ajuda da respiração alongar suavemente a coluna, sem fazer força levar o topo da cabeça em direção ao céu. Coloque a intenção de respirar leve e naturalmente, acompanhando todo e qualquer movimento;

11) A partir deste estado centrado e calmo, se concentre na ponta do nariz, mais especificamente observando atentamente o ar entrando e saindo pelas narinas;

12) Encontre o seu ritmo de respirar e carregue-o durante toda prática;

13) Ao se concentrar na respiração nos conectamos com o momento presente;

14) Respire grande, respire fundo; 
15) Muitas vezes a mente pode escapar, mas a gente volta o foco pra ponta do nosso nariz. Volte a concentração para a sensação do ar penetrando as narinas. Deixe sua atenção permanecer neste lugar durante um tempo;

\section{Encerramento da Prática:}

16) Encerre a sessåo juntando as palmas das mãos na altura do peito e agradeça;

17) Finalize sua prática afirmando: "QUE MEU CORAÇÃO SEJA INUNDADO PELA COMPAIXÃO E MINHA VIDA SEJA UM ETERNO DESFRUTAR. DEDICO E OFEREÇO OS MÉRITOS GERADOS POR ESTA PRÁTICA PARA O BEM-ESTAR DE TODOS OS SERES".

MÉTODO CURTO (indicado após 21 dias consecutivos de prática)

Sente-se confortavelmente. Junte as måos e entoe o mantra: OM AH HUM. Relaxe as mãos e concentre-se em sua respiraçăo por 21 minutos. Encerre sua prática, agradecendo e dedicando os méritos gerados para o bem-estar de todos os seres.

\section{AGRADECIMENTOS}

Do amor eu me sirvo, agradeço e ofereço meus mais nobres sentimentos à todos seres, a todos os mestres cuja sabedoria e compaixăo inundam todo o Universo. Agradeço de coração esta experiência, esta oportunidade de desfrutar as "Ondas da Vida". Por fim, gostaria de reconhecer que se não fosse por todos vocês, mestres, familiares, amigos fraternos e alunos, nada disso estaria ocorrendo. Que a PAZ reine em nos sos coraçס̊es. Que o AMOR seja o principio e o fim de todas nossas açores. OM SHANTI OM.

DÚVIDAS E SUGESTŐES:

meditarondavida@gmail.com 


\subsection{Anexo D}

\section{Entrevista transcrita na íntegra com especialista do tema.}

Esta entrevista foi realizada no Rio de Janeiro, terça-feira dia 12 de Abril de 2016, com o venerável Segyu Chopel Rinpoche, monge tibetano da linhagem Segyu, tradição Gelugpa, que além de monge é médico tibetano (naturopata) e também especialista em meditação.

Realizada em caráter extraordinário, esta entrevista se deu durante a passagem do venerável monge tibetano Segyu Choepel Rinpoche pela sua cidade natal no mês de abril de 2016. A presente entrevista foi gravada em áudio com consentimento prévio do entrevistado, e posteriormente transcrita pelo entrevistador, Rafael Loureiro Dias de Macedo. O tema central da entrevista era: A meditação como ferramenta organizacional.

Segyu Choepel Rinpoche, 68 anos, nasceu no Rio de Janeiro sob o nome de Antônio Carlos da Costa e Silva. Iniciou e completou seus estudos na Escola Militar do Rio de Janeiro e formou-se em Engenharia Elétrica na Universidade Federal do Rio de Janeiro. Paralelamente aos estudos acadêmicos tornou-se um mestre na rica tradição de cura do Brasil. Em 1983, aos 32 anos Rinpoche mudou-se para os Estados Unidos para estudar Psicologia Transpessoal em São Francisco, Califórnia. Pouco tempo após sua chegada, foi reconhecido pelo 98_ Gaden Tri Rinpoche, líder espiritual da Escola Gelug do budismo tibetano, como um mestre e detentor de renomada linhagem do budismo tibetano, conhecida como Segyu. O principal professor de Segyu C. Rinpoche foi Kyabje Lati Rinpoche (1922-2010), um dos mestres mais aclamados do budismo tibetano dos últimos tempos e antigo abade do famoso Mosteiro Gaden Shartse do Tibete. Rinpoche passou mais de vinte e cinco anos estudando com Kyabje Lati Rinpoche e outros renomados mestres tibetanos, coletando a antiga sabedoria das práticas do budismo tibetano, estudou métodos antigos, além de absorver ensinamentos da sabedoria do pensamento budista tibetano.

Em paralelo com esta formação, Rinpoche extensivamente estudou Medicina Tibetana, e em 2013 completou um curso tradicional de três anos em Medicina Tibetana no Centro de Educação Medicina Tibetana, em Milão, Itália. Tornou-se assim além de monge (tib. Lama), médico naturopata tibetanto (tib. Amchi). 
Tendo ensinado meditação para muitos estudantes em todo o mundo, desde 2003 Segyu C. Rinpoche tem dedicado seus esforços para estabelecer a Juniper Foundation como um autêntico centro de tradição em meditação para a cultura contemporânea. Vem ensinando e preparando os membros da Juniper e outros adeptos para manter e perpetuar a tradição. Segyu Rinpoche também dirige a Clínica de Cuidados Integrativos Juniper e é autor dos conteúdos escritos e palestras de treinamento em meditação para a vida moderna da fundação. Atualmente, Segyu Choepel Rinpoche diz querer levar os ensinamentos de Buda ao alcance de todas as pessoas, inclusive para o mundo corporativo.

Entrevistador: Como eu me sinto honrado de estar aqui presente, na sua frente e ter minutos de sua atenção. Considero que você está me concedendo vida, amor, isso que eu encaro como amor, desejar a felicidade para o próximo. Então fica aqui registrado meu sincero agradecimento.

Entrevistado: Eu também fico muito contente, essa idéia de colocar isso realmente é música, é canção e alegria para o meu coração. Eu vivo em um mundo onde existe o maior 'rush' do poder, do poder pelo poder, da juventude do quero, quero, quero, que no final (os jovens empreendedores) fazem produtos bons, mas a humanidade cada vez mais está perdendo o sentido humano. Então a sua iniciativa, seu propósito, sua idéia (de escrever a tese sobre meditação) me alegra muito, me alegra muito compartilhar este momento.

Entrevistador: Para começar nossa conversa, primeiramente gostaria de agradecer a oportunidade e dizer-lhe que me sinto muito honrado em estar aqui presente.

A tese de graduação a qual me referi anteriormente, debruça-se sobre o impacto da prática de meditação no ambiente organizacional e tem como principal finalidade conhecer, desvendar, analisar, evidenciar e sugerir a relevância e/ou importância da meditação e seus efeitos no âmbito da qualidade de vida nas organizações.

Tendo em vista que as empresas e organizações são basicamente compostas por seres humanos, e que boa parte de nossas vidas encontra-se voltada e inserida no contexto da vida no trabalho (local em que passamos a 
maior parte de nosso tempo), provavelmente acredito que teríamos um mundo melhor e mais harmônico, se as organizações investissem mais dos seus recursos na satisfação de seus colaboradores e na criação de um ambiente acolhedor.

Porém, frente aos mais variados desafios imputados pelo mundo moderno e globalizado, as empresas concebem a maior parte de suas diretrizes com base tão somente em resultados, esquecendo-se por vezes de que existem pessoas por trás de cada tarefa. Conforme algumas pesquisas indicam, existe sim uma relação forte entre qualidade de vida do trabalho, ambiente acolhedor e os resultados das organizações.

A meu ver, o mundo em sua maior parte é regido por um sistema econômico que visa o crescimento desordenado e o lucro financeiro, onde as empresas e organizações são os seus principais atores, que por sua vez essas organizações são compostas por seres humanos e por isso dependem de seres humanos, que estes por sua vez passam a maior parte de suas vidas no local de trabalho para se sustentar, e que cada vez mais são pressionados para atingir tão somente resultados, esquecendo-se muitas vezes do seu próprio bem estar.

Com esse cenário desenhado, as crises tornaram-se frequentes, e com isso o buraco fica cada vez mais embaixo. O resultado em geral constatado é de pessoas infelizes e preocupadas, e cada vez mais comum o surgimento de conflitos, $\ldots$

Almejo responder perguntas como: O que é meditação? Por que praticála? Porque inserir a meditação no ambiente das organizações? Como meditar pode auxiliar na melhora da qualidade de vida? Porque estudar a meditação como uma possível ferramenta administrativa organizacional? Seria relevante meditar e estudar os efeitos da meditação no que tange a qualidade de vida no trabalho?

Para sedimentar e atingir o objetivo final proposto neste trabalho, foram delineados alguns objetivos intermediários, tais como:

Identificar os benefícios percebidos pelos praticantes; verificar a opinião de funcionários e gestores a respeito da pratica meditativa e seus efeitos; e comparar os fundamentos teóricos com as opiniões a respeito da meditação.

Dito isso, como você é um grande especialista no assunto, eu gostaria que o senhor compartilhasse algo a respeito da sua formação, da sua experiência, desde os tempos da faculdade, da sua pessoa inserida no contexto empresarial, até a fundação da sua organização, que eu vejo como este treinamento de uma doutrina muito antiga e bem sucedida inserida no contexto da vida moderna. 
Entrevistado: Durante a sua fala, e neste breve início tem alguns pontos que você mencionou que as empresas são compostas por pessoas, que basicamente a alma da empresa são as pessoas. E quanto mais as pessoas são integradas no espírito da empresa de crescer, melhor, pois elas (as pessoas) também fazem parte da empresa. A realidade é que nós necessitamos do nosso trabalho, a medida que é a nossa forma de sobreviver, sem trabalho não têm a gratificação do trabalho para que eu possa sustentar a mim, a minha família e o meu lazer.

Mas veja bem, se eu (como colaborador) passo muito tempo dentro da empresa, mas eu estou contente, e eu recebo uma gratificação dela, eu tenho uma produtividade boa e um ambiente de trabalho que é pacifico e harmonioso, então por esta razão é importante a empresa investir na pessoa.

Agora, a questão fundamental, que investimento é este? Por exemplo, se eu crio uma empresa que proporciona muito lazer... tudo bem as pessoas vão se sentir um pouco relaxadas, confortáveis, mas ao mesmo tempo com o passar do tempo, as coisas se tornam do mesmo modo. Por quê? Porque nós não conseguimos investir numa qualidade fundamental nossa, que nós temos um excelente potencial, e um potencial que podemos trabalhar, viver ou ser ativos na sociedade, no sentido de produzir mais mas com uma harmonia interior. Então, a ferramenta para que isto aconteça é a meditação. Está claro?

Não é somente o ato de meditar. Com a meditação em si você vai, como se diz, ter uma calma mental, que as pessoas estejam mais, vamos dizer assim, pacíficas. Ter um 'break' ou intervalo em que toca uma campainha e você chama as pessoas, 'agora é uma meditação opcional voluntária', tem umas pessoas que vão, se interessam, outras não vão, você passa a perceber por que elas não vão, enfim... Independente da participação você vai vendo as pessoas chegando, com oportunidade de possuir um tempo de um reflexão interior, de ir se acalmando, então tudo bem. Agora, é evidente que a empresa possui os objetivos dela, ligados a produtividade, e não especificamente voltados para desenvolver os indivíduos pessoalmente. Mas introduzindo este conceito de meditação e induzindo as pessoas a entender que a maioria das confusões existentes vem dos nossos conflitos interiores, e quer queira quer não queira, eu (colaborador) participo delas (das confusões) de acordo com os padrões de comportamento que eu tenho, nas decisões que eu tomo, na falta de clareza que eu tenho e tudo mais. 
Eu me lembro quando eu trabalhei aqui (no Rio de Janeiro), na área de processamento de dados, e muitas das vezes na companhia em que eu trabalhava não possuía computadores potentes, grandes, para fazer uma folha de pagamento ou um inventário. Eu me lembro muito bem um dos trabalhos que eu tive que botar bastante energia, foi no cadastramento de todos os funcionários do PASEP, PIS-PASEP, e tinha uma data limite, um 'deadline' e o computador que eu tinha era muito pequeno (insuficiente). Então, basicamente eu cheguei para os funcionários e disse: "Olha, nós temos que terminar isso, não importa como". Daí viramos dia e noite, fizemos um acampamento e trabalhamos. Eu dizia: "Conte comigo que depois teremos um bônus". E nós fizemos! No dia seguinte eu cheguei para o meu chefe e disse que minha equipe toda estava de férias durante uma semana. Ele disse, "Eu não posso", eu disse: “Pode! Eu fiz o trabalho, eu assumo, entendeu?". Aí eu tive de 'brigar', pois se as pessoas trabalharam, elas teriam que ter um bónus. Então naquela época, eu já trabalhava holísticamente, eu via um funcionário com problemas, eu dizia: "Senta aqui, o que está acontecendo?".

Entendeu, como é o negócio? Eu realocava ele (o funcionário) e dizia: "Olha, você tem de cuidar desse problema". Então nós temos que ser humanos, mas isso não quer dizer que eu vou relaxar as datas de compromisso, que eu vou relaxar o meu planejamento, a minha organização, que eu vou relaxar, como se diz, a minha liderança e meu controle. Eu não vou relaxar com essas regras, mas eu vou integrando para que ele (o colaborador) possa entender e tomar parte disso, e como é que ele contribui melhor dessa forma.

Portanto, se ele tem algum problema, ele (o colaborador) tem realmente que tomar as responsabilidades destes aspectos (interiores). Então eu sou humano e digo: "Para o teu crescimento como pessoa você tem que cuidar dessa questão". Então esta visão, tendo isto dentro da empresa harmonizado, tendo esta ferramenta fundamental que é a meditação, eu acho que nós começaremos a ter um modelo muito mais claro e potente para as futuras operações e estas coisas todas. Eu acho que isso é muito mais, vamos dizer assim, claro na visão empresarial moderna, principalmente na visão dos "millennials" (Geração Y), que vem quebrando todos estes paradigmas interiores e crescendo desta forma. Então eu acho maravilhoso isso.

Como você me perguntou o que é meditação, meditação é o ato de se concentrar num objeto que vai empoderando a mente. Muitas vezes você vê meditação, todo mundo fazendo meditação, você senta relaxa, você está ali, por exemplo, bota um tempo para meditar vai e... acaba dormindo. Entendeu? 
A pessoa acaba tirando um cochilo, estava cansada...

Se eu (funcionário) tenho a oportunidade de tirar uma soneca de meia hora no trabalho, por quê não? Está claro? Nesse sentido, o que eu vou encarar como meditação vai ser um relaxamento, pois a pessoa vai relaxar, ela vai ganhar os benefícios por que passou uma noite agitada, por causa do filho, por que saiu para uma festa ou bebeu, não importa o quê...

Nós não temos o controle das pessoas que estão meditando, não temos o controle mental do que está acontecendo. Então esses trinta minutos em que a pessoa medita mas dorme, vai ocorrer o beneficio de um descanso, tanto fisiológico como psicologicamente, mas não necessariamente estará empoderando a mente. Ele (o funcionário) está mantendo o status quo, com um pouco de relaxamento físico e mental. É importante (para quem leciona) ter a intenção de saber e mostrar as coisas, que a meditação é uma prática que vai Ihe aumentar a sua grandeza pessoal. Aí a pessoa passa a experimentar isso, pouco a pouco, água mole em pedra dura tanto bate até que fura, ou seja, aos poucos você vai mudando este paradigma, esta resistência, pois nós temos resistência pela religião, pela fé, pela cultura, do que é estranho, o medo, não saber o que que é, principalmente em relação a meditação.

Ainda hoje, por exemplo, eu dei um entrevista em que a pessoa veio me dizer que a meditação ainda é de elite. Não é que seja de elite, é porque o outro, a pessoa mais do trabalho braçal, ela é muito consumida. Por exemplo, para ir para o trabalho ela viaja duas horas e meia na condução para chegar no trabalho. É absolutamente, extremamente exaustivo. É a fila, o trânsito... Se "perde" quatro, cinco horas da vida todo dia. Então eles, de maneira geral, não tem uma visão do controle interior.

Na nossa cultura, veja bem, você vai por exemplo num Subway (rede de restaurantes fastfood) em Paris, ou na Europa, você vê todo mundo com um livro lendo, você vê a pessoa em pé com um livro, lendo. Aqui você não vê isso, aqui você não vê este tipo de leitura, aqui se lê a tragédia. Não é que seja elitista, mas ainda não penetra na consciência do povo trabalhador, não penetra o fato de que a meditação é uma ferramenta indispensável para a sua vida. A única coisa que ele pensa nesse processo de interiorização é a religião, mas não uma meditação. Ele não se sente capaz de que ele é capaz de ter uma interiorização. Então é essa a mentalidade que tem que ser colocada na empresa, para que a pessoa entenda que possui um potencial, e esse potencial é possível de se desenvolver se ele começar a se interiorizar. Pois esta sabedoria, este estado de ter serenidade, paz e tranquilidade é independente de cultura e conhecimento 
intelectual. Ele, o indivíduo pode adquirir isso, e vai ter capacidade para absorver outras coisas como o conhecimento, a qualificação no trabalho por assim dizer.

Está claro isso? Então é nesse contexto empresarial, que têm de colocar pouco a pouco esta semente. Ou seja, vamos fazer uma meditação de concentração, vamos falar sobre textos que incentivem este potencial e meditar novamente, ao invés do que ter um período sólido de trinta minutos de "Let's Meditate!" (vamos meditar) onde as pessoas utilizem esse período para descansar e não para meditar. Está claro?

Entrevistador: Eu vejo o senhor como o portador de uma pequena grande árvore, diria como um precioso 'bonzai', que você carrega por todos os lugares. E é muito valioso, pois você oferece as mudas para todo mundo, e é a própria pessoa que vai cultivar isso...

Entrevistado: Essa observação que você fez é muito importante. Este 'bonzai', ele é pequeno como se mostra mas toda a potencialidade dele está ali. E um 'bonzai' cresce ao você perceber este detalhe. Como exemplo, eu conheço o Meng (Chade-Meng Tan, fundador do programa de meditação Search Inside Yourself da Google), eu chamo ele de Meng, ele foi o embaixador que introduziu a meditação na sede da Google no Vale do Silício. Você chega na Google está todo mundo andando. A Google tem uma estrutura perfeita, você tem restaurante, tem tudo a sua disposição e alcance, você come a hora que quer, não têm horário de almoço, você almoça a hora que quer, e têm a meditação, têm massagem , têm ginástica, têm essa coisa toda. Aí as pessoas pensam: "Ah, eu quero trabalhar lá". Magnífico. Mas isso é um detalhe. Existe o período de almoço em que você precisa dizer "almoçando", aí o almoço está ali registrado, fora isso o computador tem que estar aberto e você tem que estar transferindo megabytes (dados), não importa se você esta tomando café, etc., você tem que estar transferindo megabytes. Se você não tem a carga do dia de megabytes, o que aconteceu? Eles questionam, entendeu? Pensam que a Google tem a maior liberdade, você faz o que quer, mas por de trás tem uma contrapartida. (Rinpoche imita um aspirador sugando). Entendeu? E você tem que produzir!

Entrevistador: As pessoas confundem liberdade com libertinagem...

Entrevistado: Exatamente, então você tem que produzir. E na meditação, a pessoa deveria meditar. Eu fui lá para meditar, por isso que eu estou te 
falando. Tinham quinze pessoas, eu acredito que somente uma ou duas pessoas estavam realmente meditando, o resto estava dormindo. E é o único período que uma vez você estando na meditação, não precisa de transferência de megabytes. E eles sabem que você esta lá. E é um ambiente de extremo controle. E você não pode meditar o dia inteiro, existe alguns períodos para meditar. Então, você pode até estar cansado e tirar um sono, mas isso conta na sua produtividade. Existe o trade-off, existe essa troca. Um detalhe que eu falei com o Meng, eu disse: "Muito bem, muito boa a idéia de meditação, mas onde está a consciência, tanto sua quanto da companhia de colocar esta ferramenta a disposição, para que as pessoas a utilizem para um desenvolvimento pessoal, e a companhia diminuir um pouco esta "sugação" da pessoa e compartilhar mais um lado humanista?".

Entrevistador: Foi bem como você mencionou no último retiro de ensinamentos. A empresa, neste caso a Google, verificou e vislumbrou uma relação positiva de custo-benefício com a inserção da meditação. Ter um espaço assim exige um custo, mas ao mesmo tempo, em contrapartida o beneficio percebido é alto. Não é tanto pela visão humanista, do tipo, vou empoderar meu funcionário, e meu funcionário empoderado pode se desenvolver de uma forma muito grande. Eles não pensam necessariamente assim, eles pensam que um funcionário mais relaxado, mais calmo, mais concentrado tomará melhores decisões, e tomando melhores decisões vai afetar positivamente o rendimento da empresa, sendo assim a empresa se alinha com as diretrizes dos acionistas, dos stakeholders. É por aí?

Entrevistado: Exatamente isso. Então colocando neste contexto empresarial e corporativo, colocando estes exemplos que existem, é isso que ocorre. Eu (como empresa) quero ver minha produtividade aumentar, ou seja, eu acalmo o sujeito para ter um pouco mais de produtividade (colocando a meditação para os funcionários). É como se você mudasse uma máquina para que a máquina pudesse produzir melhor. Está claro? Você ainda não continua mudando a estrutura, para que o paradigma da civilização possa trazer bastante idéias de sustentabilidade. Todos nós precisamos de roupa, todos nós precisamos de "tudo". Mas veja bem, como um idealizador e inventor (da empresa, do produto ou serviço), existe um mercado, eu tenho uma participação, mas por outro lado aqueles que elaboram e desenvolvem o produto também tem uma participação digna. E a participação digna é o próprio crescimento deles 
também, de obter uma paz interior. Então a paz interior é de baixo para cima e de cima para baixo, ela não é unilateral, ela é multilateral.

Entrevistador: Hoje em dia, notamos a existência de inúmero estímulos e um crescimento enorme na quantidade de estímulos. Antigamente, a pessoa acordava e tinha por exemplo uma televisão em casa na qual passavam somente três canais, um ruim e dois péssimos. Hoje em dia, a pessoa acorda, ela não precisa nem ler mais o jornal para saber das noticias, ela tem tudo na palma das mãos, ela já vê o que o amigo está fazendo ou fez, ela sabe das notícias da China em tempo real, isso para mencionar o básico. Então, a pergunta que eu lhe faço é: como que se pode distribuir esta 'semente' de uma forma positiva, e como pode esta 'semente da meditação' ajudar as pessoas que estão vivendo esta onda de estímulos.

Entrevistado: Esta questão dos estímulos é interessante. Hoje nos EUA você deve ter cerca de setecentos a oitocentos canais de televisão. Mas vamos abordar um pouco a questão da produtividade e do espírito corporativo. Como é que mesmo eu tendo uma fábrica, eu possa ser competitivo o suficiente para que eu sobreviva? Pois hoje a competição é grande e altíssima. A pressão é muito grande.

Voltando a questão da televisão e dos estímulos, a pressão de competir com a mensagem é muito grande, então se exalta o sensacionalismo, as coisas ruins que estão acontecendo mundo a fora, mostra-se a miséria. Então se você verificar o que é estimulado, os estímulos veiculados na maioria das vezes é de miséria, sofrimento. Praticamente não existem estímulos de se dizer que existem coisas boas, de que existe a possibilidade de se aprender coisas boas, entendeu como é o negocio? E quando existe alguma coisa relacionada a isso, é um conhecimento doutrinador, religioso, etc. Ou seja, as pessoas sempre são estimuladas a se estimularem por algo externo e não por algo interno. Por exemplo, eu gostaria que este 'bonzai' que você se referiu fosse passado para mais pessoas, e a técnica de cuidar deste 'bonzai', que é o nosso potencial interior. Eu gostaria que as pessoas pegassem esta técnica para o bem, para que o seu 'bonzai' interior se manifeste exteriormente. Onde que está o 'bonzai'? O 'bonzai' está bombardeado, comprimido por estes estímulos, pela mídia, que de uma maneira geral veícula estímulos negativos, de medo, de terror, de consumismo ou de ... Então perdemos um pouco de... 
Veja bem, por exemplo eu fiz um café agora, quando eu cheguei aqui eu comprei o pó de café, comprei o filtro de café, mas não tinha o suporte do café, e ai eu procurei o suporte e não tinha, estava tarde, eu estava cansado então eu não fiz. No dia seguinte, o que que eu fiz? Tinha uma garrafa de água que estava terminada, cortei o topo da garrafa, fiz um funil, coloquei o filtro e fiz um suporte. Então o meu suporte para o filtro de café foi feito de uma garrafa plástica de água. Mas foi assim olha em um estalar de dedos, eu não tinha pensando nisso na hora, isso não tinha passado pela minha cabeça, só fui pensar no dia seguinte. Tinha uma pessoa aqui, que me perguntou: "Como é que você vê isso, Rinpoche? Como é que você tem essa criatividade?". É por que eu não tenho uma mente confusa, então quando eu vejo as coisas, a criatividade vem, a criatividade funcional vem, então são esses benefícios que devemos mostrar as pessoas, para que as pessoas possam ter esta criatividade. E cada vez mais temos menos criatividade, por que está tudo aqui (Rinpoche aponta para o smartphone), nas coisas tecnológicas que nos são 'impostas', mas eu não crio mais coisas, eu não tenho mais esta capacidade de ser criativo. Então voltando a meditação, voltando ao aspecto deste potencial interior, se eu começo a colocar isso para as pessoas, então pouco a pouco a pessoa vai ser criativa, vai ser criativa nas emoções, mais liberal, expansiva, mais harmoniosa e gratificante por assim dizer, e saber como controlar ou remover as próprias emoções aflitivas, e ter a capacidade de poder articular neste momento com coisas que a tornem mais funcional.

Então agora eu tenho meu café, estou tomando meu café maravilhoso por que eu tive a criatividade de fazer. Eu vejo isso muito claramente nos EUA (local onde o Rinpoche reside), eu tenho a minha assistente, ela dirige meu carro, e nós vamos diariamente para São Francisco (Califórnia), mas se ela não coloca o Waze (aplicativo de celular de navegação e transito; GPS) ela não sabe voltar para casa. Mas como não sabe voltar para casa se ela pega o mesmo caminho todos os dias? Por que falta a criatividade!

Entrevistador: Trata-se de um condicionamento, correto?

Entrevistado: Exatamente. Então eu quero chegar para você e dizer o seguinte: "Rafa, veja desta forma!" Mas se você está tão condicionado em algo, você não tem criatividade. E essa expansão (da criatividade) mais uma vez é o enfoque que as corporações devem observar. Deveriam verificar a meditação como um momento não somente para relaxar mas para buscar este potencial, 
pois é deste potencial que vem uma serenidade absoluta, que vem uma integração de criatividade e espontaneidade. Tratar a meditação não somente como um momento para relaxar pois assim os padrões internos permanecem os mesmos.

Entrevistador: Presumo eu, sem tomar conclusões precipitadas, que o senhor possui uma vasta experiência com alguns proeminentes gestores de 'start-ups' do Vale do Silício, como você mesmo já mencionou. Como acontece este trabalho da meditação, como ela existe neste mundo? Gostaria que você compartilhasse um pouco da sua visão.

Entrevistado: Está começando a ter mais penetração, clareza e evidencia. O Mark Zuckerberg do Facebook, eu o conheço de vista mas nunca obtive um cumprimento de mão, nunca tive a oportunidade mas gostaria de ter a oportunidade de falar com ele. Mas ele está introduzindo coisas interessantes, ele realmente cuida do pessoal, diz que o pessoal têm que parar, que têm que estar bem para produzir bem, entende? Se a pessoa passa a ter muitos problemas, ele chama a pessoa para saber o que está acontecendo. Ele "puxa" (estimula) as pessoas para ter mais consciência no trabalho.

É evidente que o processo (de inserção da meditação) é um processo lento, pela própria natureza e características das pessoas, mas está acontecendo. Por exemplo, hoje em dia eu tenho bastante pessoas que trabalham em 'start-ups' (empresas de tecnologia principalmente) que vem meditar com a gente (na Juniper Foundation). Por exemplo, uma das pessoas que vem meditar com a gente é um dos criadores e cofundador do Airbnb.

Entrevistador: Existe uma curiosa relação entre a criatividade e inovação nestas empresas start-ups, que por natureza são altamente inovadoras.

Entrevistado: Exatamente. Então ele (o cofundador do Airbnb) está aí com aquela criatividade toda, mas aprendendo a se posicionar, aprendendo a meditar. Um rapaz de 35 anos, com uma facilidade tremenda de atrair investidores, que criou esta empresa que ampliou muito mais a consciência das pessoas para a questão da economia colaborativa, aproveitando aquilo que existe e harmonizando com o interesse das pessoas. Ele por si só é brilhante, mas com um mente completamente... (agitada). Ele veio até a mim dizendo que não conseguia meditar. Eu falei que ele conseguia sim, nem que fosse preciso 
amarrá-lo numa cadeira (neste momento Rinpoche solta uma gargalhada). Entendeu? Então ele está tomando conhecimento. Muitas vezes as pessoas não vem por que elas acham que não conseguem meditar, então elas nem tentam, dizem "isso não é para mim, então eu não vou conseguir". Muitas vezes as pessoas se sentem envergonhadas, não sabem o que vai acontecer, possuem medo, negação e consequentemente assumem esta postura: "meditação não é para mim".

Entrevistador: Poderia-se dizer que esta é uma grande resistência, uma grande barreira de entrada?

Entrevistado: Exatamente. O pensamento do tipo: isso não é para mim! $\mathrm{Na}$ verdade é para você e é para todos! De repente, deveriam haver alguns módulos, eu diria que semiobrigatórios (Rinpoche fala da questão da meditação nas organizações). Mas botar algo para que todos estivessem presentes para que essa mensagem (de que é para todos) pudessem entrar e todos pudessem meditar. É o conta gota caindo, é água mole batendo, para que isso pudesse ir penetrando aos poucos. Desta maneira isso iria sendo assimilado, passando de um para um, de pai para filho, toda uma família, de organização para organização, de modo que este 'bonzai' que mencionamos anteriormente seja passado de mão à mão.

Entrevistador: Curioso você mencionar isso, pois ontem no meu trabalho de pesquisa (nas sessões de meditação que faço com um grupo de pessoas numa confecção de roupas), veio uma das alunas funcionárias conversar comigo, pois entre as sessões eu abro um canal de diálogo. Ela me disse que resolveu praticar (a meditação) em casa, sentou direitinho na postura, fechou os olhos e de repente a filha dela a interrompeu perguntando se ela estava ficando maluca. Ela respondeu que não, que aquilo era meditar, pediu licença e continuou a meditar. A criança pediu para ficar ao lado observando e a mãe consentiu. Assim, após ter meditado, o que a criança estava fazendo?

Entrevistado: A mesma coisa!

Entrevistador: Sim, a mesma coisa. A criança pegou rápido! 
Entrevistado: Exatamente! Qual foi a frase inicial (da criança)? "Você está maluca?!?" Por que (a primeira vista) é um escândalo, não é o comum. Entendeu?

Entrevistador: Isso, exatamente. Eu diria que a moda hoje em dia é falar que não tem tempo. Então quando você medita, e alguém questiona o que você está fazendo (quando medita), ela acha que a principio você não está fazendo nada. É um espanto não fazer "nada"! Como nossa mente é binária, é um caminho ou outro, ela funciona dessa forma, é um "processamento de dados", e a meditação seria como um desfragmentador de disco. É como se fosse assim: durante o dia inteiro a gente acessa um monte de arquivos mentais, estruturas neurais, são esses padrões internos que você menciona, e depois no final do dia, está tudo espalhado, fragmentado, e fica ainda mais bagunçado com a quantidade de estímulos que nos ocorre.

Daí eu gostaria de saber da sua parte, se este desenho, nesta determinada perspectiva é coerente. Se a meditação teria a capacidade de separar, organizar os "arquivos mentais", como a memória RAM de um computador, a memória Em Cache...

Entrevistado: Sim, ela (a meditação) tem. Possui completamente. O que acontece? A ciência tenta ser muito exata, ela tenta procurar... Até a pouco tempo atrás, uma palavra que você não poderia falar na Psicologia, na Psiquiatria era consciência. Por quê? Eles não sabiam definir o que era consciência. Consciência mais ou menos é essa memória RAM, pois num computador o RAM está ai, funcionando. A consciência é essa coisa autônoma, existe um ponto de entrada mas ela está ai. Por exemplo, você está aqui consciente, está me ouvindo, entendeu como é o negócio? E ao mesmo tempo que você está sendo estimulado, que você está escrevendo, me entrevistando, bebendo um café, eu estou aqui também bebendo um café, então é um sistema que funciona, vamos dizer assim, com milhares de entradas. É um 'network', uma rede onde existem diversos fatores. Então veja bem, hoje até a própria ciência está aqui (Rinpoche aponta novamente para o smartphone que grava a entrevista), é um número de 10 dígitos. Então para você ver, uma pessoa me chama do meio do Uruguai (Rinpoche possui uma turma de adeptos no Uruguai) e eu estou no meio do mato, como que 'de repente' ela me acha? De repente, 'puft', a pessoa me acha. É uma estacão, um país, dez números pequenos e ... 'puft', entra aqui. A mesma coisa se dá com nós. Um estimulo é produzido, você 
produz um sinal, isso vai numa rede e chega aqui, numa teia. Então essas características nossas estão ligadas com algumas características, com alguns padrões nossos, a raiva está conectada com isso, com aquilo, etc. Então é um 'network', uma rede de diversas entradas, então estes estímulos estão presentes. Durante a meditação analítica, quando eu começo a focar nestes aspectos e tópicos, eu começo a ver a característica sobre determinado ângulo, então eu começo a selecionar e reorganizar nesta diretiva. Mas a única forma de organizar isso é através da consciência da inconsciência. E aí eu começo a organizar conscientemente, está claro? Então (meditar) é uma atividade de consciência para consciência. Com a consciência do inconsciente, a pessoa começa a ser tornar consciente, e começa a organizar a consciência, e isso só se consegue ser feito mentalmente. Você não consegue fazer estas coisas de outra forma. A medida que você tem concentração e amplia o conhecimento desta rede, você começa a fazer as ligações, e expandir a consciência sem perder o foco.

Entrevistador: Olhando então por este lado, vira uma "brincadeira", um saborear. Do tipo: "Uau, isso funciona, deixa eu ver isso daqui, como funciona este padrão de comportamento..."

Entrevistado: Exatamente, exatamente! Então vamos lá, vamos analisar por quê as pessoas dizem "isso não é para mim". Por quê não seria para você? O que faz a pessoa dizer que a meditação não é para ela? O que faz a pessoa dizer que não é para ela? Qual é a alternativa?

Entrevistador: Voltando a questão da administração das organizações...

Entrevistado: A medida que a meditação oferece essa expansão da consciência sem perda de foco e concentração, ela daria mais base para as funções administrativas, como planejar, organizar, liderar e controlar, haveria maior criatividade e inovação. A meditação é o processo que ajuda nestas questões, a ferramenta para que você possa conseguir esta expansão. Hoje a neurociência começa a explicar e embasar o que eu estou falando.

Então qual é a alternativa de continuar o processo e manter a paz? É exatamente a expansão da consciência, sem perder o foco! 
Entrevistador: Então a meditação é que fornece a base dessa transformação?

Entrevistado: Justamente! Ela é a ferramenta para que você possa expandir sua consciência, ela dá base para todas as funções. Você por acaso viu a entrevista que eu dei para o programa Sem Censura (da TV Brasil apresentada pelo jornalista Leda Nagle)?

Entrevistador: Não, infelizmente não soube.

Entrevistado: Bom, o tópico do programa era "O bem que fazer o bem faz". Na conversa que foi estabelecida, um dos convidados era uma psiquiatra que ao ser questionada a respeito do bem que fazer o bem faz, foi perguntada como ela via a questão da meditação, se ela acreditava (nos efeitos e benefícios). Ela simplesmente respondeu que ela não precisava acreditar em nada, somente naquilo que era dado, pois dados são dados, somente acreditava no que era fato (concreto), que a ciência precisa ter os dados (comprovados). Daí, lá pelas tantas eu falei: "Interessante, pois a neurociência hoje chega a estes dados comprovados, por que estudantes de medicina e psiquiatria, bem como recém-formados psiquiatras, seguindo a Sua Santidade (XIV) Dalai Lama, inquiriram a respeito. Ele (Sua Santidade XIV Dalai Lama) por sua vez, disse que se eles quisessem realmente saberem o que era, que começassem a fazer uma investigação, que botassem suas mentes para investigar isso que ele iria fornecê-los os dados (uma amostra). Então esses médicos cientistas, tomando uma postura de investigação e com uma base de dados (amostra) para comprovar, conseguiram obter resultados confiáveis e hoje existem uma comprovação dos benefícios disso tudo.

Mas veja bem, se eu pegar a meditação, a neurociência, todo esse conhecimento que tem, e pegar para analisar uma massa qualquer, eu não vou obter nada. Por quê? Porque a massa que está aí não é meditadora. Então esses dados foram comprovados, os benefícios da meditação foram comprovados porque a amostra era de pessoas que são capazes de meditar. E essa amostra é proveniente da Sua Santidade XIV Dalai Lama, (oriundo) de toda uma comunidade monástica de meditadores.

Nesse momento a psiquiatra falou : "oops". Sabe por quê? Porque a ciência pode descobrir, mas se você pegar uma amostra qualquer e jogar isso, fazer o mesmo modelo com pessoas do dia a dia você não vai ter (os 
resultados), você não tem meditador. Você ensina meditação, mas a meditação não é um resultado que você vai pegar agora. Existe um tempo. Daí quando eu falei isso a psiquiatra tomou mais um susto. Então o que acontece, a neurociência só começou a prestar atenção por que alguém colocou este enfoque.

Então, você Rafael fazendo isso em termos de empresa, colocando este processo, então talvez nós vamos ver uma convergência dentro desse paradigma, para que nós possamos mudar o enfoque empresarial do mundo. Novas tecnologias vão surgindo então nós vamos ter que começar a interagir a tecnologia com o material humano, o material humano com as empresas e corporações, para que nós possamos ter uma produtividade eficaz da sociedade, da civilização, preservando ao mesmo tempo a dignidade e os valores altruístas da própria humanidade.

Entrevistador: Eu gostaria de perguntar algo muito importante: existe alguma contraindicação em relação a meditação?

Entrevistado: Existe, existe até determinado ponto Muito boa pergunta, ainda mais hoje em que a meditação se tornou uma panaceia (remédio para todos os males), todos meditam, todos tem a capacidade de meditar. Mas a meditação neste processo de reorganização, se ela não é bem direcionada, ou bem instruída, ela pode criar certas fragmentações psicológicas nas pessoas, pela própria estrutura interior da pessoa. É como se você tirasse o tapete. Então em alguns casos pode criar algumas interferências. A medicina tibetana entende bastante disso. Então em alguns casos, quando algo ligado a esta estrutura e aos fatores mentais, pode ocorrer alguma alteração, então cria-se outros problemas mentais. Então é evidente que num grupo trabalhador, ativo, você vê pessoas com uma estrutura (mental) firme. Outras mais bipolares, que oscilam muito (mentalmente), ela possui até uma dificuldade maior em trabalhar, então essas estruturas são mais perecíveis, mais delicadas no processo de meditação.

Então a pergunta fundamental é: A meditação é uma panaceia para todo mundo? Não necessariamente. Está claro? Ela tem suas contraindicações também, como tudo. Então ela precisa ser, até determinado ponto, examinada por uma pessoa que possua qualificada, que seja um 'PHD em meditação', uma pessoa que tenha a capacidade de identificar este caso, para que a meditação seja benéfica. 
Por exemplo, tem algumas pessoas que vem até a mim, que estavam meditando e eu digo pára de meditar ou vai ter um outro tipo de meditação guiada para poder reconstituir esta unidade (mental) oriunda da desfragmentação, está claro?

A meditação tem seus benefícios, ela é uma ferramenta fundamental mas eu tenho que saber como aplicá-la e colocá-la. Eu acredito que no meio empresarial, o efeito colateral dela seja muito pequeno, muito pequeno, pela própria característica seletiva das pessoas que estão trabalhando. Entendeu? Você consegue examinar logo, em princípio, a produtividade, a dispersibilidade das pessoas. Ou seja, você logo notaria a pessoa que não estaria apta para trabalhar e "eliminaria" no próprio processo seletivo natural. (Este estado de desorganização mental normalmente não se adequa as organizações). Ou seja, eu não estou dizendo que estes casos não podem existir num ambiente corporativa, pois tem crise emocional o tempo inteiro, mas a probabilidade é muito menor, pela própria circunstância do trabalho em si. O trabalho já é um espécie de processo seletivo destes casos.

Entrevistador: Para a gente finalizar, você gostaria de ilustrar alguma experiência edificante diretamente ligada com uma organização/empresa, com um corpo de funcionários de uma empresa...

Entrevistado: Olha eu tenho Adobe, o diretor dela foi nos procurar, eu dei orientação quando eles estava construindo o prédio e eles montaram um processo de meditação, e a Juniper os orientou. Não tivemos uma participação ativa de continuar o programa, mas a orientação inicial do processo foi feita. Não continuamos o programa pois demandaria muita atenção nossa, realmente não havia condição, mas durante um tempo nós orientamos o processo de meditação. Pelo que eu sei eles ainda estão no processo de estruturação.

Existe uma pessoa também que medita conosco (na Juniper Foundation), que introduziu a meditação em seu ambiente de trabalho, e era uma pessoa de recursos humanos, que fazia seleções e contratações de pessoas para outras empresas. Essa pessoa era de uma empresa consultora de recursos humanos que prestava serviço para outras empresas, uma espécie de headhunter (caçatalentos). E a meditação está instalada no processo de seleção desta empresa com a orientação Juniper.

Entrevistador: Você pode mencionar alguns efeitos dessa parceria? 
Entrevistado: Existem muitos benefícios, agora eles possuem mais clareza na hora de selecionar e contratar as pessoas, eles conseguem perceber mais a capacidade criativa das pessoas. De maneira geral, o processo de seleção deles melhorou bastante, por exemplo, aumento bastante o nível de adequação dos candidatos escolhidos para as empresas contratantes. Então isso foi uma coisa bastante absorvida neste processo.

Tem um bióloga catedrática, doutora em biologia, professora da American University, que é minha aluna, que introduziu meditação no seu departamento. Ela notou que a qualidade dos 'papers', dos artigos e trabalhos dos estudantes aumentou, que diminui o 'stress' vinculado as tarefas, o tempo de entrega dos trabalhos diminuiu, além de notar uma maior clareza dos estudantes. Para você ver que existem benefícios também desta forma.

Entrevistador: Falamos de empresas, instituições de ensino, existe por acaso algum trabalho vinculado a alguma instituições de saúde?

Entrevistado: De saúde não, ainda não. Diretamente não, mas indiretamente sim. Por exemplo, Stanford Medical School (hospital universitário) me manda pacientes, mas ainda está a nível individual, pois alguns médicos de Stanford que são meus alunos indicam o meu trabalho. Mas não acontece de instituição para instituição. Está claro? Tem outros dois médicos cardiologistas de um outro hospital 'concorrente' de Stanford, que me mandam os pacientes do centro cardíaco para que eu possa dar uma olhada neles.

Entrevistador: Você vislumbra algum dia inserir esta ferramenta dentro das instituições de saúde?

Entrevistado: Claro, claro! Mas por quê ainda eu não faço este trabalho? Por que eu acredito que tem ainda muita coisa a ser traduzida do clássico, por assim dizer, para que exista uma boa documentação, uma boa literatura ligando o clássico para a linguagem moderna. Então é esse o trabalho que eu estou fazendo, e é uma carga muito grande de horário, de trabalho para preparar os profissionais, preparar os textos, preparação de conteúdo, essas coisas todas. Então, resumindo, eu não tenho um curso formal para ter essa ligação melhor com essas instituições. Entendeu? Voltando ao estágio corporativo, especificamente falando sobre as funções administrativas, eu ainda estou na 
fase de planejamento e organização. Por isso que estão ainda nessa fase. Neste caso, eu prefiro ser cauteloso.

Entrevistador: Por fim, você gostaria de deixar uma última mensagem?

Entrevistado: A mensagem, eu fico muito contente. Apesar de eu estar nesta fase de planejamento e organização, eu já vejo muito fluxo acontecendo. No caso do seu projeto, é um desses fluxos. Então a mensagem é: continue com essa beleza, continue com esse trabalho, aumentando a sua criatividade, seguindo adiante mas sem tomar decisões precipitadas. Continuar sempre evoluindo e verificando, evoluindo e verificando, evoluindo esse pensamento para que nós possamos ter não somente a vitalidade corporativa mas a vitalidade da alma das corporações, que são as pessoas, ter as pessoas como o objetivo corporativo. Então essa é a mensagem.

Entrevistador: Muito obrigado! 